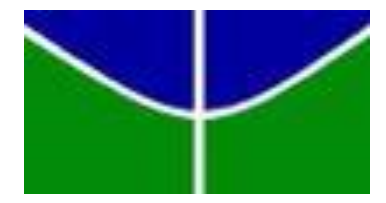

UNIVERSIDADE DE BRASÍLIA - UnB

FACULDADE DE EDUCAÇÃO FÍSICA - FEF

PROGRAMA DE PÓS-GRADUAÇÃO EM EDUCAÇÃO FÍSICA MESTRADO EM EDUCAÇÃO FÍSICA

\title{
A CRIANÇA E A ESCOLA: PRÁTICAS CORPORAIS EM TEMPOS E ESPAÇOS INSTITUCIONALIZADOS
}

TAYANNE DA COSTA FREITAS

BRASÍLIA 


\section{A CRIANÇA E A ESCOLA: PRÁTICAS CORPORAIS EM TEMPOS E ESPAÇOS INSTITUCIONALIZADOS}

TAYANNE DA COSTA FREITAS

Dissertação apresentada à Faculdade de Educação Física da Universidade de Brasília, como requisito parcial para obtenção do grau de Mestre em Educação Física. 
Ficha catalográfica elaborada automaticamente, com os dados fornecidos pelo(a) autor(a)

Freitas, Tayanne da Costa

A criança e a escola: práticas corporais em tempos e espaços institucionalizados / Tayanne da Costa Freitas; orientador Ingrid Dittrich Wiggers. -Brasilia, 2015. $142 \mathrm{p}$.

Dissertação (Mestrado - Mestrado em Educação Física) -- Universidade de Brasília, 2015.

1. Práticas corporais. 2. Infância. 3. Escola. 4. Tempos e espaços. 5. Brincadeiras. I. Wiggers, Ingrid Dittrich, orient. II. Título. 


\section{A CRIANÇA E A ESCOLA: PRÁTICAS CORPORAIS EM TEMPOS E ESPAÇOS INSTITUCIONALIZADOS}

Dissertação aprovada como requisito parcial para obtenção do título de Mestre no Programa de Pós-graduação Strictu Sensu em Educação Física da Universidade de Brasília - UnB.

Banca Examinadora:

Prof ${ }^{\mathrm{a}}$. Dr ${ }^{\mathrm{a}}$. Ingrid Dittrich Wiggers - Orientadora

Faculdade de Educação Física - FEF/UnB

Prof ${ }^{a}$. Dr ${ }^{\mathrm{a}}$ Viviane Preichardt Duek - Membro Externo

Universidade do Estado de Santa Catarina - UDESC

Prof $^{a}$. Dr ${ }^{\mathrm{a}}$ Dulce Maria Filgueira de Almeida - Membro Interno

Faculdade de Educação Física - FEF/UnB

Prof. Dr Arthur José Medeiros de Almeida - Suplente

Faculdade de Educação Física - FEF/UnB 
Foi o tempo que dedicaste à tua rosa que a fez tão importante.

(SAINT-EXUPÉRY) 


\section{AGRADECIMENTOS}

O valor das coisas não está no tempo que elas duram, mas na intensidade com que acontecem.

Por isso existem momentos inesquecíveis, coisas inexplicáveis e pessoas incomparáveis.

Fernando Pessoa

Aos meus pais, Ivan e Anatalia, pelo amor, dedicação, compreensão, incentivo diário na época de escola e faculdade. Especialmente, ao meu pai, que a todo momento me incentivara a fazer o mestrado. Pai, espero que eu nunca o decepcione. Mãe, há várias coisas que faço, ou melhor que não faço que a deixaria muito mais feliz, porém, estou deixando para que os meus irmãos as façam...assim, a senhora também se orgulhará deles (risos). Obrigada por tudo!

Meus queridos irmãos: obrigadão! Paulinha, obrigada por sempre acreditar em mim e demonstrar a "flor da pele" todas as suas emoções, muitas vezes, de maneira irritante. Obrigada por estar presente em todos os momentos. Alex, obrigada por todos os "socorros" sempre que the chamo. Obrigada pelos sobrinhos maravilhosos que tenho, Pedro Henrique e João Gabriel. Allan, nem tenho palavras - acho que já disse tudo, em todas as caronas para UnB - sempre bom ter alguém para companhia nas idas e vindas desse trajeto entre a casa e a universidade. Obrigada por compartilhar tudo, desde incentivo, apoio e lanches à conversas de toda natureza.

À professora doutora Ingrid Wiggers, pelas orientações e por ter acreditado na relevância desta pesquisa, sem a qual não teria sido possível a elaboração deste trabalho. Obrigada por ter assumido a orientação desta pesquisa de forma carinhosa, respeitando os meus limites, fazendo-me encontrar força e confiança num momento em que achava tê-las perdido. Obrigada pela confiança, mesmo 
sabendo que poderia decepcioná-la em algum momento. A senhora foi minha incetivadora desde o primeiro curso de extensão, em 2007.

À professora doutora Dulce Maria Filgueira de Almeida, por ter ministrado uma disciplina essencial na elaboração do projeto de qualificação e ainda pelo aceite em compor as bancas de qualificação e defesa. Sua contribuição foi primordial na construção deste texto.

À professora doutora Viviane Preichardt Duek, pelo aceite em compor as bancas de qualificação e defesa. Obrigada pelos textos enviados por e-mail e doces palavras de elogio. Obrigada por diponibilzar seu tempo.

Ao professor doutor Arthur José Medeiros de Almeida, pelo aceite em compor a suplência da banca de defesa. Sua análise será fundamental nesse momento final.

À professora Eliana Ayoub pelas riquíssimas orientações na defesa da qualificação. Obrigada por compartilhar suas reflexões e avaliação.

A todos os professores do mestrado. A todos os funcionários da FEF, sempre dispostos a ajudar.

A Alba pelo apoio, discernimento e calma em me orientar a procurar a Casa Thomas Jefferson para fazer o teste de profiência aos quarenta e cinco do segundo tempo.

Aos amigos da "turma" do mestrado Thainá, que mesmo de licença para trazer ao mundo um lindinho, o Paulo, esteve em contato para conversas. Mayrhon, nem sei o que dizer, mesmo! Você que é bom com as palavras! Nossa, quantas conversas, desabafos e partilha da vivência em campo e durante esses dois anos. Os almoços e saídas foram poucos, mas inesquecíveis. Nunca deixarei de ser sua amiga. 
Aos amigos, Marisa, Letícia, Claúdio, Nadson, Samir (tivemos a mesma decepção, mas estamos aqui), Robson (obrigada pela indicação da Dani), Yury. A todos os integrantes do grupo de pesquisa Imagem - UnB. Grande foi o aprendizado com vocês. Sheila, obrigada por juntas iniciarmos essa jornada e no momento mais "corrido" da sua trajetória acadêmica fazer parte desse projeto orientando a minha falta de "ideia" e disponibilizando textos fundamentais.

Aos amigos do CEF 27, por todo incentivo e amizade. Obrigada Josiney pelos textos revisados. Jack, obrigada por achar que sou uma ótima professora. Leonardo, obrigada por querer que eu sempre faça parte dessa escola. Nilda, obrigada por me liberar mais cedo sempre que precisei (nem foi muito, né? Logo peguei afastamento, risos). Tereza, obrigada pela oportunidade da sua companhia em uma importante e maravilhosa viagem. Viviane, obrigada por me ouvir. Tatiana (sem palavras), obrigada por tudo.

Fernanda (esposa do Josiney), obrigada pela amizade que se consolidou no momento mais difícil que passei na minha vida. Saudade do nosso patins dominical. Da mesma forma agradeço a Ceci, por ir ao parque naquele dia e me convidar para o banho de piscina.

Claudinha e Taiza vocês são ótimas amigas, mesmo quando estive muito afastada, vocês sempre se fizeram presentes. Taiza, obrigada por não desistir de mim, mesmo eu recusando inúmeros convites às saídas para diversão e mais ainda, obrigada pela companhia nas saídas que disse "sim".

Às amigas lulus, Léia, Mariza, Valéria e Paty saudade das nossas reuniões. Paty, minha madrinha, você é ótima.

À sempre amiga Elisângela (Lis), pelas sábias palavras e conselhos, mesmo aqueles bem difíceis de engolir e seguir. 
À professora Lucimar, por me receber em sua turma com carinho e préstimos, bem como confiança na pesquisa. A toda equipe do Centro de Educação Infantil Riacho Fundo II.

Às crianças que deram "corpo" a essa pesquisa, o meu mais sincero agradecimento e minhas saudades. Obrigada pelos desenhos confeccionados, tanto os que pedi, quanto os que recebi espontaneamente. Lindinhos, aprendi muito com vocês...

Gente, quero simplesmente dizer que agradeço a todos (mesmo aqueles que o nome não está aqui explicitado) que de alguma forma participaram desse sonho que se faz materializado nesse texto. Obrigada a todos gestos, saberes e fazeres que foram dedicados para a elaboração desta pesquisa. 


\section{SUMÁRIO}

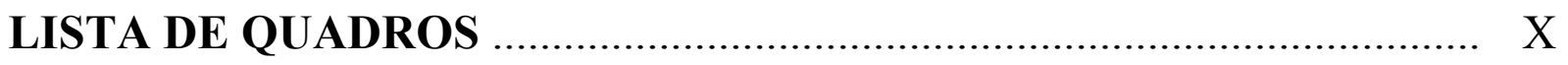

LISTA DE FIGURAS …..................................................................... XI

LISTA DE ABREVIATURAS E SIGLAS ............................................... XII

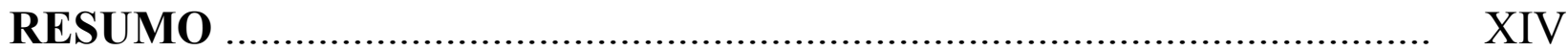

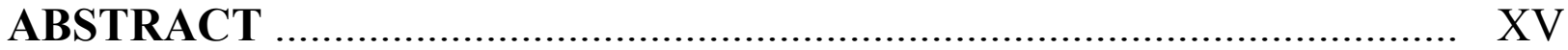

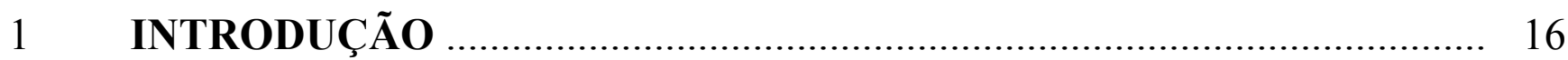

2 DIÁLOGO TEÓRICO SOBRE CRIANÇAS ……................................ 25

2.1 Olhar sociológico da infância ............................................................... 25

2.1.1 Sobre a infância de hoje ............................................................................ 39

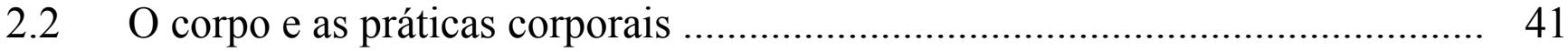

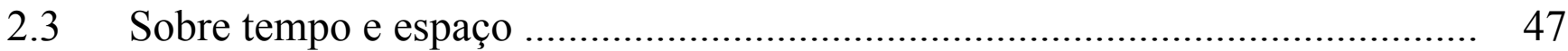

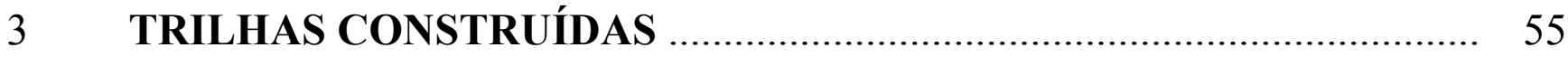

3.1 O caminho escolhido: bases teóricas e metodológicas ................................ 55

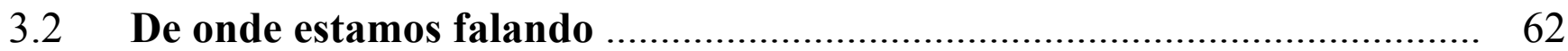

3.2.1 Localizando o tempo e o espaço: o campo de pesquisa ................................ 62

3.2.2 O campo em contexto: organização do trabalho pedagógico …….................. 67

3.3 De quem estamos falando: os protagonistas .............................................. 69

$4 \quad$ PRÁTICAS CORPORAIS NA ESCOLA …........................................... 74

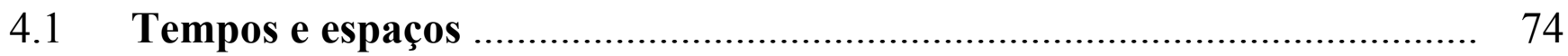

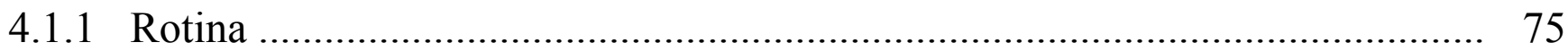

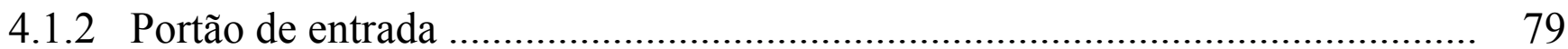

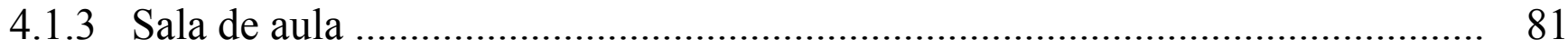

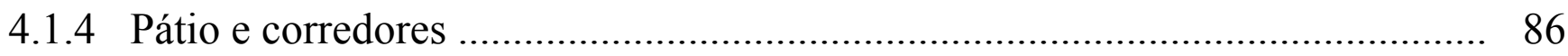

4.1.5 Parque e a quadra de esportes ................................................................. 90

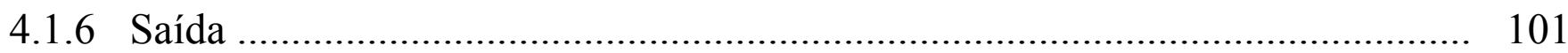

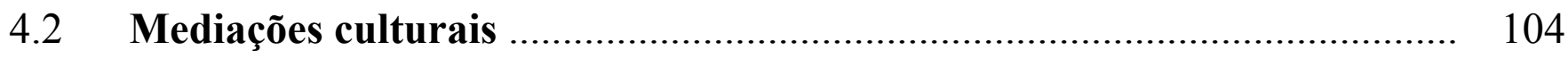

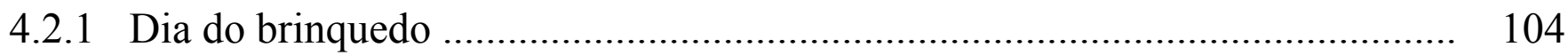

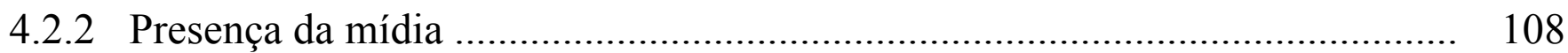

4.2.3 A brincadeira como prática corporal essencial ............................................... 115

5 CONSIDERAÇÕES PARA ESTE TEMPO E ESPAÇO ......................... 122

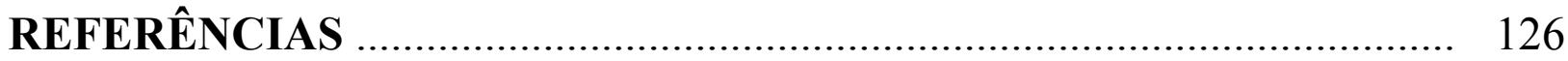

ANEXO I - DESCRIÇÃO DAS CRIANÇAS - 1 ${ }^{\circ}$ ANO “G” .................... 135

ANEXO II - TERMO CONSUBSTACIADO DO CEP ................................ 140 


\section{LISTA DE QUADROS}

QUADRO 1: Rotinas instituicionalizadas nos tempos e espaços do $1^{\circ}$ Ano “G”.... .......... 72 


\section{LISTA DE FIGURAS}

Figura 1: A escola (área externa)........................................ 64

Figura 2: A escola (planta baixa - área interna/externa)..................... 65

Figura 3: Minha brincadeira preferida: caminhão no patio. 90

Figura 4: Minha brincadeira preferida: parquinho........................ 93

Figura 5: Minha brincadeira preferida: trepa-trepa e escorregador............. 96

Figura 6: Minha brincadeira preferida: pular corda......................... 98

Figura 7: Minha brincadeira preferida: pique alto e pega-pega............... 99

Figura 8: Minha brincadeira preferida: futebol.......................... 100

Figura 9: Minha brincadeira preferida: brincar com pecinhas................ 103

Figura 10: Minha brincadeira preferida: dia do brinquedo (mamãe e filhinha)... 106 Figura 11: Minha brincadeira preferida: dia do brinquedo.................. 108

Figura 12: Minha brincadeira preferida: jogo de futebol no estádio........... 112

Figura 13: Minha brincadeira preferida: jogo de futebol pela televisão.......... 113

Figura 14: O que mais gusto de fazer na escolae em que lugar e o que menos gosto de fazer na escolar e em que lugar: parque e brincadeira de meninos..... 118 Figura 15: O que mais gusto de fazer na escolae em que lugar e o que menos gosto de fazer na escolar e em que lugar: futebol e pique pega................. 119 


\section{LISTA DE ABREVIATURAS E SIGLAS}

BIA - Bloco Inicial de Alfabetização

CEI — - Centro de Educação Infantil

$\mathrm{DMu} \quad$ - Deficiência Múltipla

DRE - - Diretoria Regional de Ensino

FCS $\quad-\quad$ Faculdade de Ciências da Saúde

FNDE - - Fundo Nacional de Desenvolvimento da Educação

GDF - - Governo do Distrito Federal

PDRF - Programa de Descentralização dos Recursos Financeiros

PPP - Projeto Político Pedagógico

RA-XXI - Região Administrativa do Riacho Fundo II

SEE-DF - Secretaria de Estado de Educação do Distrito Federal

TCLE - $\quad$ Termo de Consentimento Livre e Esclarecido

TALE _ - Termo de Assentimento

TGD - $\quad$ Transtornos Globais do Desenvolvimento

UnB - - Universidade de Brasília 


\section{RESUMO}

O objetivo deste estudo é identificar e analisar práticas corporais de crianças, considerando os tempos e espaços escolares em uma escola pública do Distrito Federal. Para tanto, realizou-se uma pesquisa de campo com elementos da abordagem qualitativa com 27 alunos de uma turma de $1^{\circ}$ ano do Ensino Fundamental, dentre elas, 20 meninos e 07 meninas. As técnicas utilizadas compreenderam observação participante, produções de desenhos e conversas com as crianças. Evidenciou-se, por meio das observações e dos desenhos, que as crianças brincam o tempo todo. Desta forma, o momento da recreação no parque e na quadra de esportes é considerado tempos e espaços de referência para esse brincar autorizado e livre. Atitudes de submissão e resistência das crianças foram percebidas, porém a rotina revelou uma série de ações que ocorreram em paralelo e seriam invisíveis e inaudíveis para quem pretende ver somente a dimensão opressora da realidade. Os próprios corpos se revelaram menos dóceis do que imaginávamos e as crianças circulam, autorizadas ou não, pelo espaço escolar. Concluiu-se que as crianças requerem um tempo e um espaço onde as práticas corporais ganhem centralidade no processo escolar.

Palavras-chave: Infância. Práticas corporais. Escola. 


\begin{abstract}
The goal of this study was to identify and assess children's bodily practices in a public school of the Federal District. For this purpose, a field research was carried out with elements of a qualitative approach. We assessed a first grade of elementary school with 27 children-twenty boys and seven girls. The techniques used were participant observation, production of drawings, and conversations with the children. Through the observations and drawings, it was possible to note that children play all the time and regard the moment of recreation, the park, and the sports court as reference time and spaces for allowed and free playfulness. Submission and resistance attitudes were noticed in the children; however, the routine revealed a series of actions that occurred concomitantly and would be invisible and inaudible to those who want to see only the oppressive dimension of reality. Their own bodies were less docile than we imagined and the children-authorized or not-moved around the school space. It is concluded that children require time and space in which bodily practices gain centrality within the school process.
\end{abstract}

Keywords: childhood, bodily practices, school. 


\section{INTRODUÇÃO}

Minha pequena história de pesquisa com crianças inicia-se na graduação ao participar do projeto de oficinas infantis no curso de Educação Física da Universidade de Brasília (UnB). O estágio realizado com crianças entre 1 e 6 anos foi repleto de descobertas, brincadeiras e incansáveis sorrisos. Mas também um período de muito aprendizado e responsabilidade. Certa de que havia encontrado um campo de atuação na Educação Física prestei concurso e fui aprovada para professora da Secretaria de Educação do Distrito Federal. Nesse momento inicial da carreira profissional os caminhos trilhados, por força da política da educação básica no DF à época, em 2005, me distanciaram do trabalho e contato com as crianças. Durante quase dez anos atuei em outros níveis de ensino, como exemplo, séries finais do ensino fundamental, ensino médio e educação de jovens e adultos.

Ao retomar os estudos acadêmicos me reencontrei com as crianças e desta vez, descobri outra via de aproximação por meio de pesquisa. Do curso de especialização em educação física escolar elaborou-se um trabalho de conclusão intitulado Educação física nas séries iniciais: as práticas corporais infantis no ambiente escolar. Esse estudo teve a participação das crianças matriculadas no $4^{\circ}$ ano do ensino fundamental como sujeitos e apresentou as primeiras reflexões acerca das práticas corporais realizadas por crianças em ambiente escolar, bem como foi a primeira aproximação com as novas perspectivas de se fazer pesquisa com crianças. O olhar centrou-se no encantamento em perceber que as crianças são sujeitos socioculturais, que podem reproduzir e apresentar novos sentidos às práticas sociais e culturais.

Em continuidade com o processo de formação acadêmica, o mestrado permitiu prosseguir no caminho de se fazer pesquisa com crianças, sobretudo, ao 
me oportunizar fazer parte do grupo de pesquisa "Imagem" da Faculdade de Educação Física com sede na Universidade de Brasilia (FEF-UnB). O grupo desenvolve estudos e pesquisas com ênfase no protagonismo infantil, evidenciando aspectos da educação, educação física, educação do corpo, das práticas corporais, mídia-educação e suas implicações nas interações sociais das crianças, bem como estudos relacionados à formação de professores. A criança e a escola: práticas corporais em tempos e espaços institucionalizados contribui no debate realizado pelo "Imagem". Evidenciam-se neste trabalho aspectos do relacionamento das crianças e seus corpos nos tempos e espaços criados e organizados pela escola pressupondo, que este local deveria garantir a criança o acesso às práticas corporais como jogos, brincadeiras, danças, teatros entre outras atividades, o que asseveraria a qualidade tão esperada da escola pública para esse nível de ensino.

Salienta-se que, do ponto de vista tradicional, as pesquisas envolvendo crianças versam sobre a concepção de infância e criança vivida e apreendida a partir das construções feitas pelos adultos, nas quais, muitas vezes, a criança não pode discursar, defender-se ou falar sobre si mesma. "Nessa perspectiva, a infância é vista enquanto um ensaio para a vida adulta e a socialização é um processo por meio do qual as crianças devem se 'conformar'[...]" (BUSSSIMÃO, 2009, p.7).

Atuais estudos presentes na área de educação e sociologia apontam para a tentativa de compreender o período da infância em suas singularidades, procurando legitimar o indivíduo, desde a mais tenra idade, como cidadão de direitos. A criança é entendida como ser social e histórico, dotado de diversas potencialidades. Compreendem a criança a partir do seu contexto social e cultural. Procuram apreender as diferentes formas de ser criança. Concebem o universo infantil não mais como um reflexo do mundo adulto. A abordagem da 
sociologia da infância defende o reconhecimento das crianças como atores sociais, no sentido de que elas "[...] não somente reproduzem regras, valores, hábitos e comportamentos do mundo adulto como, principalmente, criam e recriam realidades e dão outros sentidos ao mundo" (DELGADO E MÜLLER, 2006, p. 178).

Sarmento (2004) apresenta uma respeitável contribuição a essa perspectiva sociológica ao salientar que, para além de considerar as crianças como atores sociais, é preciso considerar a infância como categoria social. O autor acentua que a "infancia" é relativamente independente dos sujeitos empíricos que a compõem, visto que ocupa uma posição estrutural. $\mathrm{O}$ avanço da definição da infância como categoria geracional permite a superação de uma infância universal, considerada como tábua rasa, que deve ser moldada conforme padrões estabelecidos pelos adultos, reconhecendo na recolha das vozes das crianças fator preponderante para o conhecimento das culturas infantis. Dessa forma, aponta-se a necessidade de se considerar diferentes crianças e diferentes infâncias.

Corsaro (2011), por sua vez, exprime a ideia segundo a qual as crianças, na sua interação com os adultos, recebem continuamente estímulos para a integração social, sob a forma de crenças, valores, conhecimentos, disposições e pautas de conduta, que, ao invés de serem passivamente incorporados em saberes, comportamentos e atitudes, são transformados, gerando juízos, interpretações e condutas infantis que contribuem para configuração e transformação das formas sociais. Deste modo, as crianças não herdam apenas uma cultura constituída que lhes atribui um lugar e papeis sociais, mas realizam transformações nessa cultura.

Em contexto educacional, Mascioli (2012) indica que a educação deve considerar a criança e seu desenvolvimento integral, englobando entre outros 
aspectos, o exercício de sua capacidade criadora e sensorial, assim como o estímulo às suas diferentes formas de linguagens e expressividades. Imergir no universo infantil requer uma aproximação e sensibilidade para perceber o que as crianças querem dizer com suas brincadeiras e atitudes. Com efeito, no entendimento de Martins Filho (2011) pesquisas com ênfase na escuta das vozes das crianças permitem obter, em primeira mão, informações e opiniões sobre seu mundo educacional, social e cultural. Isso significa interagir, analisar e contextualizar, historicamente, as falas captadas das crianças.

De acordo com Ariès (1981), a escola tal como a conhecemos hoje, é uma instituição que surge com o advento da modernidade, destinada ao cuidado e educação das crianças e jovens. À escola coube a função de educar na medida em que o tempo e competência da família eram considerados escassos no cumprimento desta tarefa. Os saberes diversos, especializados e necessários à formação das novas gerações demandavam, cada vez mais, um tempo próprio dedicado ao trabalho de apresentação e sistematização de conhecimentos dessa natureza, diferente, portanto, daquele organizado pela família.

Os tempos e os espaços escolares são ricos em manifestações simbólicas que percorrem vários contextos e ao mesmo tempo possuem particularidades em relação aos outros espaços sociais. Faria e Vidal (2000) revelam que tempos e espaços da escola operam como uma espécie de discurso que instituem, em sua materialidade, um sistema de valores, um conjunto de aprendizagens sensoriais e motoras, assim como uma semiologia que recobre símbolos estéticos, culturais e ideológicos. Assim, os padrões de tempo e espaço podem afirmar ou negar saberes e culturas, bem como estimular ou restringir as diferentes formas de linguagens, inclusive as práticas corporais.

São nos tempos e nos espaços educativos que acontecem os rituais: separam-se os alunos por sexo, idade, séries; organizam-se filas e carteiras; 
estabelecem-se os espaços hierárquicos entre alunos, professores e funcionários. Conforme anteriormente assinalado, o tempo e espaço não se definem somente por sua cronologia objetiva ou por sua metragem, mas pela forma como são experimentados transformando-se em ambiente de interações e vida. A materialidade dos tempos e espaços e os sinais de interação humana que neles são percebidos indicam princípios que sustentam o trabalho cotidiano com as crianças, concepções de infâncias, práticas culturais e corporais.

O tempo nos constitui. Nele organizamos o fluxo da vida e da composição social. Segundo Francisco (2005), o tempo é um conceito difícil, e sua abrangência depende da realidade natural e social, ou seja, o tempo é produto cultural e histórico da sociedade. O tempo escolar é vivenciado predominantemente sob o controle do relógio. Funciona como um mecanismo que desencadeia ações, instaura e indica as mudanças de atividades, resumindo uma série de acontecimentos a partir de uma regularidade, ritmo e harmonia do trabalho escolar. De acordo com Fontana (2003), o tempo cronológico garante uma organização produtiva em termos de eficiência, rapidez, precisão e padronização. A escola atua regulando o controle do tempo e do espaço para a produção de sujeitos destinados a uma sociedade orientada por uma lógica de mercado capitalista e para uma crescente exigência de formação de competências.

Os espaços da escola, por sua vez, são identificados a partir do que acontece neles, com o que é ou não é possível fazer, seja porque tenham sido criados para realizar alguma coisa concreta, seja porque tenham consolidado um uso determinado dos mesmos. Na visão de Buss-Simão (2012), quando a sala está arranjada de uma determinada maneira, ela predispõe uma experiência com a dimensão corporal, ou seja, a forma de organizar o tempo e o espaço das 
atividades e também do mobiliário permite ao corpo experiências, seja nas possibilidades ou nos constrangimentos.

Foucault (2007) destaca que em qualquer sociedade o corpo está acondicionado no interior de poderes que impõem limitações, proibições e obrigações. Esses poderes são as instituições públicas e privadas que regulam a vida em coletividade, tais como: instituições militares, hospitalares e escolares. Portanto, é importante lembrar que o corpo é construído historicamente.

No entendimento de Buss-Simão (2009), percebe-se que no Brasil, a ideia que se faz sobre o corpo (não só no âmbito dos estudos da infância), está fortemente vinculada ao campo das ciências naturais e biológicas. Isto porque corpo se apresenta como um organismo vivo funcional para a manutenção da saúde do homem. Essa perspectiva evidenciada no final do século, e início do século XX, se constituiu hegemônica, sobretudo com o advento do higienismo. Este movimento preconizava normas e hábitos que colaboraram com $\mathrm{o}$ aprimoramento da saúde coletiva e individual. Segundo Castellani (1993), na concepção higienista o corpo é visto sob duas formas: "corpo higiênicoeugênico", pautado na necessidade de corpos fortes e saudáveis para a defesa da pátria, e "corpo alienado-produtivo", muito comum em virtude do processo de industrialização uma vez que havia um "adestramento" físico de modo a capacitar o indivíduo ao trabalho.

Wiggers (2003) aponta que na civilização moderna, o corpo foi mitificado, em primeiro nível, por sua natureza animal e à escola coube a missão de seu disciplinamento, constando uma subvalorização das práticas corporais infantis em detrimento dos conhecimentos cognitivos. Richter e Vaz (2005) entendem que a educação do corpo na educação infantil relaciona-se a hábitos de higiene, de alimentação, de pausa para o sono, momento de ir para o parque e de 
atividades orientadas em sala de aula. Os autores apontam para uma disciplinarização dos corpos das crianças pelos adultos no âmbito escolar.

No entanto, as concepções sociais de corpo refletem outro pensamento, na medida em que elas permitem uma melhor compreensão do ser humano e suas relações com o mundo. Essas reflexões visam compreender o movimento corporal e seu significado filosófico, social, cultural, biológico, econômico, político e histórico, frente aos seus múltiplos modelos de condutas e expressão tais como gestos, hábitos, ritos, enfim, práticas corporais. Em vista disso, Silva (2010) expõe que pensar o corpo, em particular o corpo das crianças pequenas, não está dissociado das possíveis mediações com as políticas do corpo dos adultos, da família, da mídia e da sociedade como um todo. Dessa maneira, é importante compreender as práticas corporais, de forma macro e micro-social e num dado tempo-espaço histórico, isto é, no ambiente escolar.

As práticas corporais constituem-se como uma forma de linguagem em âmbito corporal e são frutos do processo de diferentes construções coletivas e potencialidades individuais. De acordo com Soares (2014), as práticas corporais podem ser configuradas como pedagogias que intervém sobre o corpo. São manifestações corporais concebidas por diversos processos educativos e requerem um aprendizado próprio e adequado para cada ocasião e contexto. Dessa maneira, pode-se afirmar que as práticas corporais estão presentes em todos os tempos e espaços da vida humana, portanto são integrantes da cultura escolar, trazendo inscritas as marcas do processo histórico, político e cultural.

Soares (2001) revela que o corpo pode traduzir, revelar e evidenciar formas bem precisas de educação, modos bastantes sutis de inserção de indivíduos e grupos. Partindo desse pressuposto, Soares (2014, p. 221) apresenta a noção de educação do corpo, “[...] como uma produção significante da atividade social de homens concretos, tem um caráter polissêmico, que permite 
evocar sempre a ideia de movimento, de passagem de transformação, na constituição de pedagogias e de políticas voltadas ao corpo, em suas permanências, rupturas e continuidades". Entendemos que as práticas corporais, dentro da estrutura e do contexto escolar são as brincadeiras, os jogos, as danças e os esportes capazes de serem representados pela cultura infantil. Nessa perspectiva, surge uma indagação: como se constituem as práticas corporais realizadas pelas crianças em âmbito escolar, considerando os tempos e espaços organizados pelos adultos?

Isso posto, o presente estudo destacou os dados produzidos a partir das perspectivas vivenciadas e relatadas pelas próprias crianças e teve o objetivo de identificar e analisar práticas corporais de crianças, considerando os tempos e espaços escolares em uma escola pública do Distrito Federal. Estabeleceu-se como objetivos específicos: a) Identificar as práticas corporais das crianças nos tempos e espaços estruturados pela escola; b) Descrever e analisar como as crianças se apropriam dos tempos e espaços propostos pela estrutura escolar, por intermédio das práticas corporais.

Sendo assim, estruturou-se o texto da seguinte forma. No capítulo "Diálogo teórico sobre crianças" apresenta-se o referencial teórico cujo objetivo é o de fundamentar e nortear o estudo, exibindo aspectos da literatura referentes aos conceitos abordados. Em, "Olhar sociológico da infância" apresenta-se o conceito de infância a partir da concepção sociológica, onde se contextualiza a criança como sujeito capaz de se relacionar com os adultos e com seus pares de maneira a reproduzir e reconstruir aspectos da cultura histórica e social. A discussão intitulada "Práticas corporais" consiste em desvelar características sobre a educação do corpo num enredo mais amplo e das práticas corporais como parte desse todo. Em seguida, "Sobre tempo e espaço", pretendeu-se esclarecer 
aspectos conceituais dessas duas categorias com o propósito de situá-las no cenário escolar.

O capítulo "Trilhas construídas" destina-se à descrição de pressupostos epistemológicos, metodológicos e o delineamento da pesquisa de campo, bem como o lócus e os sujeitos da pesquisa. Para compilar os dados, dispôs-se da observação participante com registro em diário de campo, da produção de desenhos pelas crianças, conjugados com a oralidade. A permanência em campo atendeu pressupostos de uma pesquisa qualitativa com influência fenomenológica, bem como certa orientação etnográfica.

Nos capítulos das análises deu-se destaque para as práticas corporais das crianças nos tempos e espaços estruturados pela escola. Identificou-se três categorias: a primeira intitulada de Tempos e espaços subdivididos em rotina, portão de entrada, sala de aula, pátio e corredores, parque e a quadra de esportes e a saída. Com o subtítulo Mediações culturais, essa segunda categoria aborda aspectos do dia do brinquedo e da mídia e sua influência. E, por último $A$ brincadeira como prática corporal essencial aponta análise referente à apropriação das crianças por meio das práticas corporais dos tempos e espaços da escola, destacando a brincadeira como aspecto essencial no seu dia dia escolar.

"Considerações para este tempo e espaço" reune reflexões acerca das análises desenvolvidas, articulando-as com os objetivos propostos e base teórica. Propoe-se possibilidades no trato pedagógico quanto à modulação do tempo e estrutura organizacional do espaço, visando especialmente, às especificidades das crianças no início da vida escolar. 


\section{DIÁLOGO TEÓRICO SOBRE CRIANÇAS}

\subsection{Olhar sociológico da infância}

Eu peço

Olhe para mim e me veja por dentro.

Me ouça e tente me entender.

(FRIEDMANN, 2005, p.15)

Definir a infância é ponto crucial para esta pesquisa. Entende-se que os estudos em que as crianças são protoganistas não podem deixar de apontar a origem da preocupação com a infância que caracteriza as sociedades contemporâneas. Dessa forma, objetiva-se delinear o tema, tendo como ponto de partida uma breve explanação do movimento histórico e teórico em que o conceito de infância, tal como o reconhecemos hoje, foi em certa medida gestado. Ainda nesse referencial, apresenta-se aspectos da infância na atual conjuntura sociocultural.

O conceito de infância não corresponde a uma categoria universal natural, como algo homogêneo e de significado óbvio. A infância emerge como realidade social, mediada historicamente, por isso se percebem os grandes contrastes em relação ao sentimento de infância no decorrer dos tempos. $\mathrm{O}$ que hoje pode parecer uma aberração, como a indiferença destinada à criança pequena, outrora era algo absolutamente normal. "[...] as circunstâncias e condições de vida das crianças são, contemporaneamente, enquadráveis naquilo que tem sido uma das mais constantes facetas da infância: o caráter paradoxal como elas são consideradas pelas sociedades dos adultos" (PINTO e SARMENTO, 1997, p.11).

O crescente processo de industrialização e urbanização, a densidade demográfica, as transformações da organização social e da família, a individualização do sujeito e o discurso pedagógico foram alguns determinantes 
na constituição dos sentimentos modernos de infância e, consequentemente, na produção de um conceito sobre ela.

A temática da infância afirmou-se como objeto histórico com a pesquisa de Philippe Ariès (1981), um clássico na área, que representa um ponto de partida ao percorrer as transformações dos sentimentos e atitudes em relação à criança desde a Antiguidade até a Sociedade Moderna. Ele se utilizou da pesquisa historiográfica e sua narrativa é permeada pela iconografia religiosa e leiga da Idade Média. Sua contribuição para a análise das transformações do sentimento de infância ao longo da história é indispensável para a confirmação do pensamento, de que não se trata apenas de modificações biológicas ou naturais, mas de categorizações sociais e históricas sujeitas às transformações que ocorrem na sociedade.

Durante a Idade Média, muitas crianças viviam misturadas aos adultos, não havendo grandes diferenças em termos de vestimentas, jogos, atividades, aprendizagens e até mesmo em relação ao trabalho. Sendo assim, eram vistas, em geral, como adultos em miniatura, cuja educação se dava em meio a todos os membros da comunidade.

Dados históricos asseveram que a população estava concentrada no campo (cerca de $80 \%$ das pessoas viviam na zona rural) e, apesar de alguns períodos de maior crescimento demográfico, o número de habitantes era pequeno. O baixo crescimento da população resultava do elevado número de mortes, pois a média de vida, na época, não ultrapassava os 40 anos de idade. Os historiadores calculam que, de cada 100 crianças nascidas vivas, 45 morriam ainda na infância. Era comum a morte de mulheres durante o parto e os homens jovens morriam nas guerras ou vítimas de doenças para as quais ainda não se conhecia uma cura (Pedrero-Sánchez, 2000). 
A falta de higiene, de água tratada e de um sistema de esgoto, provocou surtos de epidemias que mataram milhares de pessoas. A peste negra, por exemplo, que se espalhou pela Europa, somente no período de 1348 a 1350, matou cerca de 20 milhões de pessoas. Além das pestes, nesta época, outras doenças provocavam altos índices de mortalidade: tuberculose, sífilis e infecções generalizadas provocadas pela falta de assepsia no tratamento das feridas. Bastante limitada, a medicina não tinha ainda desenvolvido tratamento adequado para muitas doenças. Além disso, as distancias, as dificuldades de locomoção e o número reduzido de médicos tornava ainda mais crítica a situação dos doentes que na maioria das vezes eram atendidos em boticários ou curandeiras e se medicavam com ervas e rezas. Aliás, essas mulheres curandeiras, que a Igreja tratava como feiticeiras, também foram duramente perseguidas e mortas pela Inquisição (Pedrero-Sánchez, 2000).

A historiadora Pedrero-Sánchez (2000) revela o quão dramática era a situação das crianças, muitas vezes abandonadas em estradas, bosques ou mosteiros pelos pais, que não tinham como sustentá-las. Além disso, havia também grande número de órfãos, devido ao elevado índice de mortalidade no parto: a falta de higiene provocava a chamada febre puerperal, que causava a morte da mãe, e a incidência de blenorragia (doença sexualmente transmissível) muitas vezes contaminava o filho, causando cegueira. Numa população supersticiosa, que interpretava todos os acontecimentos naturais como expressão da vontade divina, a doença era vista como punição pelos pecados, inevitável, não se fazendo necessário muito esforço para a sobrevivência dos pequenos. Quando sobreviviam, as crianças eram festejadas por serem consideradas fortes e logo eram inteiradas no mundo dos adultos para aprenderem a vivê-lo o mais rápido possível (Pinheiro, 2000). 
Ariès (1981) afirma que naquele momento histórico havia, no meio europeu, uma indiferença com relação a essa fase da vida, configurando a ausência de um sentimento em relação à infância. A infância era considerada apenas uma época de transição passageira, sem maiores implicações, não sendo reconhecida socialmente como possuidora de especificidades próprias. As crianças tornavam-se independentes de suas mães ou amas de leite e misturavam-se ao mundo dos adultos e de seus trabalhos. Consideravam-na um adulto em miniatura, pois tinham tarefas semelhantes as pessoas mais velhas e todos os tipos de assuntos eram discutidos na sua frente.

Somente a partir do período Renascentista, uma vez que ele expressou um movimento histórico de reorientação nos campos econômico, social e politico, observa-se mudanças nesse cenário. A criança saiu do anonimato e passou a figurar em cenas de retratos de famílias. Os pais começaram a se preocupar mais com a higiene e a saúde física dos filhos, pois o objetivo era evitar mortes, o que possivelmente tenha implicado na constituição de novas relações afetivas entre os entes familiares. "As inúmeras mortes que, paulatinamente, foram gerando um sentimento de piedade levando aos pais a vontade de manter seus filhos vivos [...]" (PINHEIRO, 2000, p. 22).

Observa-se que tais atitudes conformaram o sentimento de paparicação. As crianças, segundo Ariès (1981), não passariam de brinquedinhos frágeis para muitos adultos. Oliveira (2005) descreve que o sentimento de paparicação onde a criança em seus primeiros anos de vida era tratada como um objeto querido, um bichinho de estimação, o qual possibilitava alegria e divertimento. Passada esta fase, observa-se que a presença da criança no seio familiar era muito significativa, pois ela marcava a sucessão parental e, sendo ela considerada pública, evidenciava-se a preocupação que a família tinha em garantir a sobrevivência da criança. Diante disso, a criança participava das atividades e 
aprendizagens, nos espaços públicos da aldeia, da casa e redondezas (Gélis, 1991).

As mudanças evidenciadas nos séculos XVIII e XIX, em consequência dos encaminhamentos da Renascença para a era Moderna, tiveram influências decisivas no reordenamento familiar. Assim, gradativamente, a criança começou a ser valorizada por ela mesma e não mais por toda a família que representava. Os pais começaram a se preocupar mais com a higiene e a saúde física dos filhos. Surge, então, um outro sentimento para com a infância: a moralização. A moralização realizada pelo adulto preconizava a disciplina por meio dos ensinamentos ligados à Igreja e à família.

Pinheiro (2000) relata que o interesse de moralização da infância, se constituiu, inclusive com a criação de espaços físicos bem delimitados. Com os colégios, a infância se tornou objeto de estudo, compreensão, análise e normalização, o que também contribuiu em seu processo de conceituação. Podese notar que surge um novo sentimento, no sentido de conduzir a criança no caminho direcionado pelo adulto. A criança é reconhecida socialmente, mas encontra-se submissa ao adulto.

Perante esse engendramento, o trabalho de Ariès (1981) é emblemático na explicitação do lugar da infância na Modernidade, particularmente no contexto europeu. $\mathrm{O}$ autor expõe como a criança passa de uma indistinção na relação com os adultos no cenário medieval, onde ocupava o lugar de adulto em miniatura, para o reconhecimento de suas especificidades, seja no âmbito familiar ou educacional.

Na perspectiva de outra concepção de infância é possível perceber que um novo cenário surge ao longo do século XX. Diversas áreas do conhecimento, em especial a sociologia da infância, despontam com o objetivo de estudar as especificidades da infância, buscando sobretudo superar métodos reducionistas. 
"A sociologia da infância ajuda a entender as crianças de forma mais plena e livre da discriminação imposta pela situação desigual em que vivem" (BUSSSIMÃO, 2007).

Alguns pesquisadores são referências em estudos que objetivam compreender a criança a partir de pressupostos da sociologia da infância. Sobressaem-se Corsaro (2011), Florestan Fernandes (2004), Montandon (2001, 2005), Sarmento (2004) e Sirota (2001, 2008). Em observância aos estudos desses autores, evidencia-se um consenso em relação à compreensão da infância como construção social, constituída por sujeitos concretos e de direitos, percebida como uma categoria histórica e estrutural da sociedade.

Para a autora francesa Régine Sirota (2001), o mais urgente era a própria consolidação da sociologia da infância. A autora relata que a emergência de uma sociologia da infância poderia ser simbolizada mediante a aparição da noção de ofício de criança. A proposta era constituir a infância, enquanto objeto de pesquisa demonstrando reconhecimento de carências e segmentação do objeto.

Tomar a sério a criança, reservando-lhe o lugar de um objeto sociológico em sentido pleno, é o primeiro desafio da noção de ofício de criança, pois representa uma ruptura difícil de efetuar no modo de pensar da sociologia da educação, da qual é interessante rever as etapas (SIROTA, 2001, p. 14).

Segundo Sirota (2008), outro fator importante é romper com o conceito equivocado de infância segundo o qual na infância o sujeito ainda não está pronto, caracterizando apenas um projeto de pessoa. A autora afirma que "[...] trata-se de romper a cegueira das ciências sociais para acabar com o paradoxo da ausência das crianças na análise científica da dinâmica social com relação a seu ressurgimento nas práticas e no imaginário social" (SIROTA, 2008, p. 11).

A ideia é pensar a infância sob o olhar das suas próprias práticas diárias, do cotidiano das crianças. Sirota $(2001,2008)$ apresenta um esforço em desenvolver investigações sobre temas ainda pouco explorados como o estudo 
das festas de aniversário das crianças e não apenas sob o estigma da escolarização, como se isso fizesse naturalmente parte desse ser. A autora tenta romper com a proposta hegemônica de uma infância passiva restrita a conceitos universais naturalizados.

Sirota $(2001,2008)$ apresenta uma síntese de alguns traços importantes que ajudam a definir as características da sociologia da infância: primeiro, a infância é uma construção social. Ou seja, para entender as crianças é preciso analisar de que maneira a infância é vista pela sociedade em questão. A infância não é um fenômeno ligado à imaturidade biológica, não é apenas mais um elemento natural ou universal dos grupos humanos, é histórico e social. Essa desnaturalização da definição, sem negar a imaturidade biológica, enfatiza a variabilidade dos modos de construção da infância em todas as dimensões históricas e reintroduz o objeto infância como um objeto ordinário de análise sociológica. Segundo, a infância é considerada não simplesmente como um momento precursor, mas como um componente da cultura e da sociedade. Terceiro, a infância se situa como uma das idades da vida que necessitam de exploração específica, como a juventude ou a velhice, já que é uma forma estrutural que jamais desaparece, não obstante seus membros mudem constantemente e, portanto, a forma evolua historicamente. Quarto, as crianças devem ser consideradas como atores em sentido pleno e não simplesmente como seres em devir. Quinto, as crianças são ao mesmo tempo produtos e atores dos processos sociais. Trata-se de inverter a proposição clássica, não de discutir sobre o que produzem a escola, a família ou o Estado, mas de indagar sobre o que a criança cria na intersecção de suas instâncias de socialização. Isto quer dizer que a criança é ativa em seu processo de socialização. E, por último, a infância é uma variável da análise sociológica que se deve considerar em sentido pleno, articulando-a a variáveis clássicas como a classe social, o gênero, ou o 
pertencimento étnico. A Sociologia da infância dedica-se, portanto, em romper com a insensatez e contradição das ciências sociais sobre a ausência das crianças na análise científica da dinâmica social.

Cléopâtre Montandon (2001) ao analisar os principais trabalhos sobre a criança escritos em língua inglesa identifica que as discussões também partem da premissa de rompimento com as abordagens clássicas da socialização infantil e aponta para a construção social da infância como um novo paradigma. Em seus estudos, investigou sobremaneira as instituições sociais como, por exemplo, a escola e suas práticas educativas parentais. Entende que pesquisas fundamentadas na sociologia da infância permitem às crianças protagonizar suas histórias.

Montandon (2005) destaca a importância de se estudar a experiência das crianças e seus pontos de vista para a compreensão dos diferentes fenômenos sociais que lhes dizem respeito. Na perspectiva da sociologia da infância, sua experiência é considerada no âmbito das estruturas sociais e do contexto particular nos quais se insere. A partir de vários exemplos no campo da educação de crianças, a autora argumenta que não basta examinar as práticas educativas de seus educadores, mas que é necessário compreender as perspectivas das crianças ou, dito de modo mais simples, que importa analisar não apenas o que os educadores fazem com as crianças, como também o que estas fazem com o que se faz com elas. Aponta que o interessante seria conhecer o ponto de vista das próprias crianças, no que diz respeito às práticas de socialização que lhes são destinadas. Independentemente de seu interesse, entender como a própria criança vive, quais são seus sentimentos, suas ideias e ações quando dos diversos processos educativos de que é participante.

Em seus estudos, Montandon (2005) revela que as crianças sabem exprimir-se a respeito de suas experiências e que seus relatos matizam e 
completam o que sabemos sobre os processos educativos. Como toda e qualquer coletividade social, as crianças constroem e compartilham uma cultura que lhes é específica. Salienta que o que estas pensam nem sempre corresponde com o que os pais pensam que elas pensam. Entretanto, pensam, e seu pensamento não é inferior.

Ao levar muito mais em consideração o ponto de vista das crianças, o sentido que atribuem à sua socialização e à sua experiência, poderíamos avaliar melhor a influência da educação parental. Vimos que elas têm uma visão informada do papel e das qualidades dos que são encarregados de sua educação assim como do funcionamento das instituições educativas; elas exercem uma introspecção notável sobre seu próprio modo de aprender e de interagir com os outros (MONTANDON, 2005, p. 495).

Em resumo, a contribuição dessa autora para asseverar um conceito sociológico de infância considera o ponto de vista das crianças como indispensável à compreensão de sua experiência. Salienta que novos trabalhos nessa perspectiva poderão sem dúvida trazer, no futuro, um suplemento de sentido às pesquisas sobre a educação familiar e escolar. A autora observa que o objeto "[...] parece, pois, construir-se na intersecção de um certo número de disciplinas das ciências sociais, produzindo uma recomposição disciplinar" (MONTANDON, 2001, p.12). Significa que essa recomposição discute a própria evolução da sociologia da educação e que é preciso retomar a análise do processo de socialização por meio de uma articulação com outros campos da sociologia (sociologia da família, sociologia política, sociologia do direito, demografia), capaz de explicitar o problema da articulação com a sociologia geral.

Além disso, também se deve considerar a experiência das crianças sob uma perspectiva geracional da infância, pois, de fato, cada geração de crianças vive uma experiência coletiva particular. Neste contexto, Sarmento (2004) apresenta uma respeitável contribuição ao salientar que para além de considerar 
as crianças como atores sociais é preciso considerar a infância como categoria social do tipo geracional. $O$ autor acentua que a infância é relativamente independente dos sujeitos empíricos que a compõem, visto que ocupa uma posição estrutural. O avanço da definição da infância como categoria geracional permite a superação de uma infância universal, considerada como tábua rasa, que deve ser moldada conforme padrões estabelecidos pelos adultos, reconhecendo na recolha das vozes das crianças fator preponderante para o conhecimento das culturas infantis. As crianças vivem a infância de modos diferentes em razão da classe social, etnia, raça, gênero e idade. Dessa forma, aponta-se a necessidade de se considerar, para diferentes crianças e diferentes infâncias.

Sobre a categoria geracional, Qvortrup (2010) destaca que a infância existe enquanto um espaço social para receber qualquer criança nascida e para incluí-la por todo o período da sua vida. Quando essa criança crescer e se tornar um adulto, a sua infância terá chegado ao fim, mas enquanto categoria a infância não desaparece, ao contrário, continua a existir para receber novas gerações de crianças.

\begin{abstract}
A infância continua a existir, ainda que sujeita a transformações; ao mesmo tempo, também notamos - se acompanharmos a seta crescente - que todos os períodos individuais da infância desaparecem por completo. As relações entre gerações não assumem necessariamente a forma de conflitos ou divisões; elas podem simplesmente ser consideradas como diferenças ou, na realidade, como interesses em comum. O ponto importante é que a perspectiva geracional é indispensável para chegar a um consenso sobre a natureza da relação (QVORTRUP , 2010 p. 638).
\end{abstract}

A infância como "categoria social do tipo geracional" (SARMENTO, 2004, p.19) se identifica por uma característica comum: pertencer ao mesmo escalão etário, ao qual é socialmente moldada, de tal modo que todos os indivíduos do grupo, apesar das diferenças que existam entre eles, são influenciados pela estrutura social, ao mesmo tempo que a influenciam, que se 
mantém independentemente dos membros concretos que a constituem em cada momento histórico, ainda que varie em consequência das mudanças na estrutura da sociedade e nos seus modos de articulação simbólica.

Sarmento (2004) entende que o conceito de geração é central na configuração sociológica da infância, porque permite resgatar, quer no plano da análise de estrutura social, quer no plano da análise da ação social das crianças, aquilo que é distintivo. A infância é uma categoria geracional que necessita ser estudada de modo a articular os elementos de homogeneidade (estatuto social, características macroestruturais comuns, como a demografia, o investimento associado às crianças, etc.) com os elementos de heterogeneidade, inerentes ao fato das crianças serem também desigualmente distribuídas pelas diferentes categoriais sociais (classe social, gênero, etnia, subgrupos etários).

Corsaro (2011), por sua vez, exprime a ideia de que as crianças, na sua interação com os adultos, recebem continuamente estímulos para a integração social, sob a forma de crenças, valores, conhecimentos, disposições e pautas de conduta, que, ao invés de serem passivamente incorporados em saberes, comportamentos e atitudes, são transformados, gerando juízos, interpretações e condutas infantis que contribuem para configuração e transformação das formas sociais. Deste modo, as crianças não herdam apenas uma cultura constituída que lhes atribui um lugar e papeis sociais, mas realizam transformações nessa cultura.

Corsaro (2011), em sua trajetória de investigação com crianças, tornou-se referência no estudo dos temas sobre cultura de pares, relações entre adultos e crianças, crianças e crianças, métodos etnográficos de pesquisas com crianças e processos de socialização, bem como os tipos de brincadeiras mais recorrentes em suas rotinas. Para tanto, o sociólogo considera que é em torno do conceito de 
"reprodução" que ocorrem as principais mudanças no campo da sociologia da infância.

O conceito de reprodução parte do alargamento referente a sua matriz originária de conservação e continuidade da estrutura social (nesta perspectiva, as crianças seriam envolvidas em instituições de reprodução social), para a reprodução pelas crianças dos mundos sociais dos adultos, denominada de reprodução interpretativa. De acordo com Delgado e Müller (2006), não se trata apenas de adaptação ou interiorização das regras, hábitos e valores do mundo adulto, as crianças atribuem significados ao mundo que as rodeia.

O termo reprodução significa que as crianças não apenas internalizam a cultura, mas contribuem ativamente para a produção e a mudança cultural. Significa também que as crianças são circunscritas pela reprodução cultural. Isto é, crianças e suas infâncias são afetadas pelas sociedades e culturas das quais são membros. Já o termo interpretativa captura os aspectos inovadores da participação das crianças na sociedade, indicando o fato de que as crianças criam e participam de suas culturas de pares singulares por meio da apropriação de informações do mundo adulto de forma a atender aos seus interesses próprios enquanto crianças (CORSARO, 2002, p.31).

As crianças criam atividades baseadas no ato de brincar, na imaginação e na interpretação da realidade de uma forma própria dos grupos infantis. A constante atividade das crianças, as apropriações de elementos do meio sociocultural de origem só confirmam o que os(as) sociólogos(as) da infância enfatizam, principalmente, no que diz respeito à lógica peculiar das crianças, a qual é diferente da lógica dos adultos e que caracteriza suas culturas de pares (Delgado e Müller, 2006).

Corsaro (2011) define cultura de pares como um conjunto de atividades, rotinas, artefatos, valores e preocupações que as crianças produzem e partilham na interação com seus pares, isto é, com as outras crianças. A produção de sua cultura de pares pelas crianças não é uma questão de simples imitação. As crianças apreendem criativamente informações do mundo adulto para produzir 
suas culturas singulares. Esses são aspectos que comumente se evidenciam na proposta contemporânea de sociologia da infância, uma produção que está voltada para as infâncias e as crianças.

No Brasil, o importante trabalho de Florestan Fernandes (2004) contribuiu ao mesmo tempo com a cultura brasileira e com a sociologia. Enfatiza, o autor, que para estudar a criança é preciso tornar-se criança. Isto é, não basta observar seu universo é preciso adentrar em seu meio, é preciso viver suas brincadeiras, suas preocupações, suas paixões e desilusões, enfim é preciso viver suas culturas. Seu trabalho é referência para compreensão do ser criança, haja visto ter realizado uma minuciosa observação, registro e análise do modo como as crianças brasileiras constituiram seu processo de socialização, nas décadas de 1930 e 1940.

Seu estudo denominado As "Trocinhas" do Bom Retiro foi um registro de elementos constitutivos das culturas infantis, captadas a partir de observações sobre grupos de crianças residentes nos bairros operários da cidade de São Paulo que, depois do período da escola, juntavam-se nas ruas para brincar. Entendendo a criança como participante ativo da vida social, esse autor observou, registrou e analisou o modo como se realiza o processo de socialização das crianças, como constroem seus espaços de sociabilidades, quais as características destas práticas sociais, afinal, como se compuseram as culturas infantis.

A cultura infantil possibilita formação das trocinhas, um modo de produção e reprodução simbólico próprio das crianças. Fernandes (2004) define que as trocinhas são experenciadas pelas crianças que nela convivem e brincam , mas numa relação direta com os elementos culturais oriundos do mundo adulto. Nas palavras do autor: "existe uma cultura infantil - uma cultura constituída de elementos culturais quase exclusivos dos imaturos e caracterizados por sua natureza lúdica atual" (FERNANDES, 2004, p. 215). 
Fernandes (2004) destaca que esses elementos culturais contituídos pelas crianças em seus próprios grupos, são justamente os padronizados pelo grupo social, correspondendo aos usos e costumes das pessoas adultas. Desse modo, o grupo infantil se apresenta, ao pesquisador, como um grupo de iniciação, ou como uma antecipação à vida do adulto.

O autor desenvolve uma dupla abordagem analítica, tendo como bases teóricas os estudos dos campos do folclore a da sociologia: "Desse modo, diz Fernandes, o enfoque folclórico e o enfoque sociológico revelam sua complementaridade, o primeiro servindo de subsídio para o segundo de modo que se pode falar na utilização do folclore como um método de trabalho" (GARCIA, 2001, p. 152).

Para a sociologia da infância são importantes as ideias e os ensinamentos de Florestan Fernandes, especialmente no que diz respeito ao seu entendimento sobre educação e cultura infantil, e o modo como o pesquisador deve eleger e focalizar a criança na sua investigação, já que apresenta as crianças como sujeitos primeiros de sua pesquisa.

Em conclusão a esse percurso histórico, com o intuito de compreender o ser criança, destacamos que mesmo que a criança ainda não possa se auto-gerar precisa ser considerada como sujeito social. Sendo assim, a relação entre adultos e crianças não pode seguir um viés de submissão mas sim, de mediação, interação e negociação. Portanto, é preciso considerar as crianças como participantes ativos da cultura. A compreensão de infância que vislumbramos, nesta pesquisa, deve estar exposta aos conhecimentos historicamente construídos pela civilização, haja visto que as teorias mostram o quanto a infância é suscetível aos conhecimentos produzidos culturalmente. A especificidade da geração da infância contemporânea evoca, sobretudo, a importância de dar voz às crianças a partir de desconstrução das imagens estabelecidas anteriormente. 


\subsubsection{Sobre a infância de hoje}

Compreende-se hoje que a criança não é um mero constructo biológico, mas sim apresenta carcterísticas especiais e sua concepção deve observar aspectos sociais, culturais e históricos. As transformações que marcam o momento atual, consequentemente, vêm impregnando a condição da infância. Os inúmeros engendramentos sociais e econômicos afetam sobremaneira as crianças e o modo cultural que se expressam.

O indivíduo gestado na modernidade, sob os pressupostos do liberalismo econômico e do "bombástico" avanço tecnológico do século XX passou a ser, também, um indivíduo científico. Esse ideário cria um novo sujeito que representa os novos moldes de civilização, onde até mesmo as relações entre pais e filhos são cada vez mais mediadas pela ciência e pela técnica. Mais do que uma afetuosidade ligada aos instintos, apresenta um cuidado ligado à eficácia (GHIRALDELLI, 1996).

A globalização sob a ordem do capitalismo tem como um dos seus pilares a incorporação dos vários segmentos da população à lógica do consumo. Nesse aspecto, as crianças constituem hoje uma importante "fatia do mercado", o que tem provocado um incremento da produção cultural voltada para a infância, sobretudo daquela da ordem da cultura do consumo e da cultura de massa.

Segundo Caparelli (1997), no início dos anos 1980, as crianças começam a ser vistas como clientes, consumidoras, tornando-se um segmento autônomo do mercado. $\mathrm{O}$ fenômeno é traduzido pela forte publicidade que passa a ser dirigida a elas e por um marketing que combina informação, persuasão, diversão e venda, com forte poder de convencimento. Além dos produtos tradicionais infantis, como brinquedos e histórias em quadrinhos, muitos produtos familiares passam a ser relacionados com as crianças, como eletrodomésticos, móveis, remédios, roupas e sobretudo produtos da indústria alimentícia. 
Nessa trilha da transformação da criança que brinca, mas também consome, a lógica capitalista passa a ordenar a programação de vida das famílias em total consonância com as mudanças na economia. É paupável a progressão dessa indústria cultural destinada às crianças e justamente com base na realidade que as estratégias midiáticas constroem e confundem o imaginário coletivo.

[...] inventando e alimentando fantasias das mais variadas, nem sempre realizáveis. Os computadores, a Internet, o telefone conduzem as crianças a descobertas e sensações muitas vezes distantes da esfera da sua realidade, além de mostrarem-se como um novo mundo a ser conquistado. Realmente a tecnologia produz novas idéias, sensações e representações que levam as crianças a se constituírem de forma diferenciada daquelas que não têm acesso a ela (PINHEIRO, 2000, p. $55)$.

Reforça-se, então, o entendimento de que a infância se constrói de diferentes formas nos diversos lugares, a partir dos diferentes contextos sociais, econômicos e culturais nos quais as crianças estão inseridas. Não há uma única forma de pensar e compreender a infância. Percebe-se que há uma reconfiguração da cultura infantil frente aos novos processos tecnológicos e midiáticos. As práticas corporais ultrapassam a experiência corpórea, alcançam também o espaço virtual. Desta maneira, as brincadeiras são pautadas por diversos aspectos, porém estão sempre presentes nos tempos e espaços do cotidiano infantil, especialmente no ambiente escolar. 


\subsection{O corpo e as práticas corporais}

Longe de ser singular, o corpo é plural (LOURO, 2012, p. 12).

O corpo tem se apresentado como um dos mais complexos e instigantes objetos de análise que nos possibilita a compreensão da realidade na qual estamos inseridos. "O corpo é o que se diz dele e o que se faz dele" (LOURO, 2012, p. 12), dele se espera que se ajuste às normas, que repita e recite comportamentos. No corpo, no movimento humano e em todo o universo das práticas e técnicas corporais estão intrínsecos valores sociais, culturais, políticos e econômicos do momento histórico que perpassa a trajetória do ser humano em sociedade. "A nomeação dos corpos e a inscrição das marcas pretendem sugerir seus caminhos e possibilidades" (LOURO, 2012, p. 13). Com o intuito de compreender o tratamento dispensado ao corpo e os vários usos que fazemos dele, bem como dialogar com os objetivos propostos nesta pesquisa, optamos em realizar uma narrativa histórica e teórica a partir das diferentes concepções de corpo.

$\mathrm{Na}$ Grécia antiga, a relação entre homem e corpo ficou conhecida filosoficamente como a "estética da existência" (SILVA, 1996, p. 245). De acordo com a autora, um dos ideais gregos sobre o corpo era a busca pela felicidade por meio de um desenvolvimento pleno e harmônico e em profunda interação com o cosmo. Essa relação ocorria ao longo de toda a vida e era alcançada de maneira individual. Prevalecia a concepção de ser humano saudável através da prática do corpo belo e verdadeiro obtido a partir da realização de regimes "[...] que eram seguidos ao longo de toda existência e que diziam respeito a todas as atividades humanas" (SILVA, 1996, p. 245).

No transcurso da Idade Média, sob o regime da cristandade, o corpo perpassou grande negação. Uma brutal diferença de representação, se 
compararmos com aquela primeira matriz que acabamos de analisar. Para a Igreja o corpo cede lugar à obscuridade do pecado e da culpa sem a mediação do luto e o tempo da sublimação. O corpo é um fardo arcabouço da alma. "Esta mística ensina que cada homem é composto de um corpo material e mortal, fonte de lascívia e tentações, e de uma alma imaterial e imortal que necessita ser preservada das abominações do corpo"(SIQUEIRA, 2011, p.52). No caso dessa desqualificação do corpo, a inspiração está na linha de pensamento e nas doutrinas filosóficas de Platão para quem a alma preexiste ao corpo e, um pouco mais suavizada, na filosofia de Aristóteles, segundo o qual a alma é a forma do corpo. As práticas relativas aos cuidados e manutenção de um corpo belo eram renegadas e consideradas pecaminosas. Nesse período desapareceram as termas, o teatro, instituições gregas e romanas, evidenciadoras do culto e dos cuidados com o corpo. Segundo Silva (1996), observava-se somente incentivo à preparação militar e aos jogos de guerra.

Conforme relata Siqueira (2011), com o Renascimento esse enquadramento do corpo sofreu profundas alterações. A mais significativa delas foi, talvez, a dessacralização do corpo e a ascensão de uma ciência positiva sob a égide da prevalência da natureza ao sobrenatural, onde se encontra o corpo em carne e osso. Com o desenvolvimento do pensamento iluminista, no século XVIII houve, um intenso movimento filosófico e pedagógico que se entrelaçou com o desenvolvimento da sociedade e da burguesia. Nesse contexto ocorreu um processo de racionalização do corpo, difundido por meio do desenvolvimento da ciência médica. A partir desse momento, o homem foi tomado como uma expressão da vida biológica, como um organismo e o corpo como unidade biológica e lugar da vida humana. A concepção de corpo assumiu uma conotação de funcionalidade, ou seja, é definido como um conjunto de órgãos arranjados segundo as leis anátomo-fisiológicas. 
Segundo Silva (1996) nesse tempo histórico verifica-se um novo modelo de valorização do corpo em observância às práticas corporais, antes individualizadas e com características de força e agressividade para um conjunto de gestos graciosos com respeito à perfeita geometria entre o corpo e o material empunhado, no caso uma lança. "O corpo e seus movimentos e adereços começam a adquirir outro código de valores, ainda em ambientes públicos" (SILVA, 1996, p. 245). Aqui se visualizava um trato corporal de grande importância para as relações que se fundamentava entre o coletivo. "Os múltiplos adereços sobre o corpo, buscando enfeitá-lo e marcando forma de representação, também demonstra essa preocupação com o estar em público, espaço para o qual o corpo era instrumentalizado" (SILVA, 1996, p. 246).

Nessa ótica, o corpo é entendido como algo a ser subjugado. Houve a “[...] descoberta do corpo como objeto e alvo do poder"(FOUCAULT, 2007, p.117), socialmente oprimido e manipulável, visto sob o prisma do ganho econômico a qualquer custo.

O controle da sociedade sobre os indivíduos não opera simplesmente pela consciência ou pela ideologia, mas começa no corpo e com o corpo. Foi no biológico, no somático, no corporal que antes de tudo, investiu a sociedade capitalista. O corpo é uma realidade bio-política (FOUCAULT, 2007, p.80).

No século XIX, a partir do processo de industrialização, herdou-se a ideia de corpo máquina, recorrente do mecanicismo do século XVII. O corpo como uma máquina que funciona perfeitamente e pode ser conhecido racionalmente e treinado por processos disciplinares educativos. Assim, segundo Foucault (2007, p.131), o princípio da disciplina sobre o corpo irá agir “[...] na ampliação de suas aptidões, na extorsão de suas forças, no crescimento paralelo de sua utilidade e docilidade, a sua integração em sistemas de controle eficazes e econômicos".

Gonçalves (2011) descreve como a sociedade industrial impôs ao homem a descorporalização do seu corpo. Ao longo do processo civilizatório, percebe-se 
uma evolução contínua da racionalização, o homem foi tornando-se, progressivamente, o mais independente possível da comunicação empática do seu corpo com o mundo, reduzindo sua capacidade de percepção sensorial, e aprendendo simultaneamente a controlar seus afetos, transformando a livre manifestação de seus sentimentos em expressões e gestos formalizados. Ou seja, as habilidades corporais e a aparência do corpo/imagem corporal são moldadas, manipuladas e sugestionadas pelo processo de civilização em especial da indústria corporal.

Com o advento da escolarização nos séculos XIX e XX, a educação das crianças passa a ser institucionalizada. A escola surge numa relação dialética com a sociedade reproduzindo as suas estruturas de dominação. O ambiente escolar também irá revelar mecanismos de controle sobre o corpo, seja na maneira de pensar ou na maneira como o corpo é "distribuído" dentro da escola: posturas corporais, hábitos, recreio, filas, gestos e da própria educação física que irá focar na esportivização e no rendimento através de critérios de desempenho e produtividade.

Esse disciplinamento tem como intuito docilizar o corpo através do controle de ações, adestramento de gestos, manipulação de desejos, a fim de mantê-lo submisso à ordem vigente, não manifestando qualquer atitude que fuja dos padrões de comportamento denominados corretos na sociedade. Nesse aspecto, Veiga-Neto (2000) aponta que esse confinamento, essa disciplinarização contribui na distribuição dos corpos de maneira menos caótica, já que é preciso que o poder articulador de Estado atinja igualmente a todos.

No interior das instituições escolares, em especial para as crianças pequenas, Richter e Vaz (2005) apontam para um engendramento da educação do corpo na infância, classificados em: corpo-higiene, corpo-alimentação, corposono, corpo-parque e corpo-atividade orientada. O corpo-hiegiene remete à 
prestação de hábitos de limpeza corporal. No momento do corpo-alimentação observa-se orientação de autoconservação física, por meio da ingestão de alimentos. O chamado corpo-sono envolve a concepção de repouso e recuperação para a próxima atividade, porém, o que se verifica é, muitas vezes, uma imposição à continuidade da rotina $\mathrm{O}$ corpo-parque é destacado como o momento de liberdade para os pequenos. São permitidas a realização das práticas corporais, porém, sob a vigilância do adulto. O corpo-atividade orientada ocupa a maior parte do tempo das crianças e ganham destaque os castigos e punições advindos das transgressões.

Para Soares (2005) o corpo pode traduzir, revelar e evidenciar formas bem precisas de educação, modos bastantes sutis de inserção de indivíduos e grupos. Partindo desse pressuposto, Soares (2014, p. 221) apresenta a noção de educação do corpo, "[...] como uma produção significante da atividade social de homens concretos, tem um caráter polissêmico, que permite evocar sempre a ideia de movimento, de passagem, de transformação, na constituição de pedagogias e de políticas voltadas ao corpo, em suas permanências, rupturas e continuidades". Dessa maneira, entendemos que as práticas corporais podem ser consideradas uma categoria no universo da educação do corpo. $\mathrm{Na}$ estrutura do contexto escolar são as brincadeiras, os jogos, as danças e os esportes capazes de serem representadas pela cultura infantil.

As práticas corporais constituem-se, portanto, como uma forma de linguagem em âmbito corporal e são fruto do processo de diferentes construções coletivas e potencialidades individuais. De acordo com Soares $(2005 ; 2014)$, as práticas corporais podem ser compreendidas como pedagogias que intervém sobre o corpo. São manifestações corporais concebidas por diversos processos educativos e requerem um aprendizado próprio e adequado para cada ocasião e contexto. Dessa maneira, pode-se afirmar que as práticas corporais estão 
presentes em todos os tempos e espaços da vida humana e portanto são integrantes da cultura escolar, trazendo inscritas as marcas do processo histórico, político e cultural.

Em contraponto aos reducionismos aos quais o corpo foi submetido, pesquisas contemporâneas expressam a necessidade de compreender o corpo e suas relações com o mundo e seus sujeitos. O corpo é considerado como uma sede de signos sociais, pois sua configuração é permeada por construção cultural onde cada sociedade se expressa de diversas formas, por meio de corpos diferentes. Para Daolio (1995, p. 37), “[...] existe um conjunto de significados que cada sociedade escreve nos corpos dos seus membros ao longo do tempo, significados estes que definem o que é corpo de maneiras variadas".

Marcel Mauss (1974) teve o mérito de, pela primeira vez, incluir o corpo e o que ele chamou de técnicas corporais no âmbito dos estudos antropológicos. Esse autor considerou os gestos e os movimentos corporais como técnicas criadas pela cultura, passíveis de transmissão através das gerações e imbuídas de significados específicos. Técnicas corporais seriam as maneiras com que os homens se servem de seus corpos a partir de um determinado contexto social. É importante considerar que Mauss (1974) entende o corpo como fato social, pois é parte de uma triangulação formada por aspectos biológicos, psicológicos e sociais.

Pelo o exposto, as concepções sociais de corpo caracterizaram um novo momento de que na medida em que elas permitem uma melhor compreensão do ser humano e suas relações com o mundo. As reflexões sob esse enfoque visam compreender o movimento corporal e seu significado filosófico, social, cultural, biológico, econômico, político e histórico, frente aos seus múltiplos modelos de condutas e expressão tais como: gestos, hábitos, ritos, enfim, práticas corporais. 
Nessa perspectiva, os conhecimentos sobre o corpo numa dimensão cultural e histórica tornam-se também centrais no âmbito dos estudos da infância.

Nesse sentido, Buss-Simão e Rocha (2007) analisaram o corpo a partir de suas diferenças culturais, ao invés de suas semelhanças biológicas, pois o corpo é também o lugar onde se inscrevem os elementos culturais presentes nas experiências que os sujeitos humanos vivem ao longo de sua existência. Ressaltam a importância da interconexão entre essas duas perspectivas para a compreensão do ser humano como "biocultural" e apontam que esse entendimento produz consequências no processo educacional e social. Entendem, sobre esse aspecto, que a ação educativa carrega consigo uma fortíssima dimensão interventiva e destacam a importância dos educadores na construção e prática de políticas-pedagógicas emancipatórias sobre o corpo e a infância. O destaque, recai sobre a importância de pensar as práticas corporais a partir do relacionamento sujeito, tempo e espaço, pois as formas de intervir nos corpos variam conforme a perspectiva assumida.

\subsection{Sobre tempo e espaço}

O tempo fala, o espaço conversa (HALL, 1996, p. 27).

O tempo não é um conceito simples nem de fácil compreensão. Ele pode ser definido de diferentes formas, como, por exemplo, há o tempo natural (ciclo dos dias e das estações), o pessoal (a sequência da duração de eventos percebida subjetivamente), o sócio-cultural (o tempo em diferentes culturas) e o tempo ensinado (o dos relógios e calendários). Indiscultivelmente, o tempo nos constitui. Nele organizamos o fluxo da vida e da composição social. Segundo Viella (2003), o tempo é um conceito difícil, e sua abrangência depende da realidade natural e social, ou seja, o tempo é produto cultural e histórico da 
sociedade. "O tempo biológico, tempo de trabalho tempo doméstico, tempo livre, tempo da cidade, tempo da técnica são portadores de acontecimentos e estão carregados de sentidos" (VIELLA, 2003, p.150).

Na Idade Média, a administração do tempo ficava encarregada à Igreja. Os homens utilizavam como medida de tempo os movimentos do sol, da lua e das estrelas, que comumente chamamos de fenômenos naturais. Le Goff (1979) exemplifica esse período como tempo do mercador e o tempo da Igreja. Referindo-se ao tempo da Igreja, ele o considera como de Deus, pertencente à ordem da natureza. Ao tempo do mercador ele o considera como um tempo tecido pela própria trama de seus valores. Mas, posteriormente, verificamos que essa dominação do tempo realizada pela Igreja veio se chocando com as transformações nas relações econômicas vivenciadas no período. Nesse contexto:

Da mesma forma que o camponês, o mercador está submetido, na sua actividade profissional, em primeiro lugar ao tempo meteorológico, ao ciclo das estações, à imprevisibilidade das intempéries e dos cataclismos naturais. Neste aspecto, e durante muito tempo, ele só necessitou de submissão à ordem da natureza e de Deus e só teve como meio de acção, a oração e as práticas supersticiosas. Mas quando se organiza uma rede comercial, o tempo torna-se objeto de medida (LE GOFF, 1979, p. 51) .

Segundo Le Goff (1979), com as alterações verificadas na economia, a partir do século XIV, o tempo da Igreja, ritmado segundo ofícios ligados a atividades religiosas, foi sendo substituído, "[...] pelo tempo mais exactamente medido, utilizável para as tarefas profanas e laicas, o tempo dos relógios" (LE GOFF, 1979, p.53). Com base no estudo de Thompson (1991), o relógio foi incorporado à vida cotidiana das sociedades modernas para marcar o ritmo das ações, medir os rituais e ordenar os ciclos da existência, pelo ritmo do capital.

Norbert Elias (1998) afirma que os relógios são mecanismos físicos construídos pelos homens para transmitir mensagens de regulação dos 
comportamentos do grupo. Ele explica ainda que "[...] nas sociedades avançadas, os relógios ocupam um lugar eletivo dentre os dispositivos destinados a representar o tempo" (Elias, 1998, p. 15). De acordo com Viñao Frago (2001), a incorporação do relógio aos espaços tem, pois, além de um significado cultural, uma clara função pedagógica que se acrescenta às intenções educadoras das estruturas espaciais das instituições.

É nesse contexto que nas palavras de Viñao Frago (2001, p. 44), “[...] o relógio se incorpora à escola como um organizador da vida em comunidade, do tempo da infância". Ele marca a entrada, a saída e o recreio na escola. Ele controla, organiza e coordena, aliando tempo e espaço às primeiras aprendizagens da criança. O uso do relógio no espaço escolar é uma tentativa de perpetuação do controle social. Sobre esse aspecto Munakata (2001) discorre:

[...] que a figura do relógio permite, assim, conceber a instituição de uma nova temporalidade educacional que, sendo uniforme e unívoca (ao menos tendencialmente), crie condições para ensinar tudo a todos. Tudo, na medida em que as matérias devem ser distribuídas em unidades de tempo segundo um plano prévio; a todos, pois doravante serão abstraídas diferenças de toda sorte (sociais, econômicas, de gênero etc.), de modo a nivelar os alunos reduzindo-os a destinatários de hora-aula (MUNAKATA, 2001, p.49).

Nesse aspecto, o pensamento comeniano já se encontra no registro de uma concepção mais moderna, abstrata e quantitativa, quase galilaica, do tempo. Comenius (1985 apud Munakata 2001) apresenta como modelo para definir as bases organizacionais da escola, o relógio e a tipografia. O relógio regula ritmado e harmônico o trabalho escolar e a tipografia se empenhava em escrever o livros com maior rapidez e precisão.

De acordo com Viella (2003), a noção dominante de tempo que subsidia o currículo escolar das crianças é o tempo espacializado e quantitativo: tempo de aula, tempo de brincar, de tomar banho, de se alimentar, do repouso, de crianças de diferentes idades nos espaços das salas de atividades, do parque, do refeitório, 
do banheiro, do pátio. O tempo escolar é vivenciado predominantemente sob o controle do relógio. Funciona como um mecanismo que desencadeia ações, instaura e indica as mudanças de atividades, resumindo, uma série de acontecimentos a partir de uma regularidade, ritmo e harmonia do trabalho escolar.

De acordo com Fontana (2003), o tempo cronológico garante uma organização produtiva em termos de eficiência, rapidez, precisão e padronização. A escola atua regulando o controle do tempo e do espaço para a produção de sujeitos destinados a uma sociedade orientada por uma lógica de mercado capitalista e para uma crescente exigência de formação de competências.

Os espaços, por sua vez, são identificados a partir do que acontece neles, com o que é ou não é possível fazer, seja porque tenham sido criados para realizar alguma coisa concreta, seja porque tenham consolidado um uso determinado dos mesmos. Viñao Frago (2001) analisa a escola enquanto arquitetura e espaço que ocupa na sociedade e a produção de discursos e práticas. Os espaços escolares devem ser considerados como parte do currículo escolar, uma vez que também educam. Atualmente, almeja-se uma escola que possa atender a todos igualitariamente, proporcionando um ensino de qualidade. $\mathrm{O}$ espaço escolar não é neutro e está impregnado de signos, símbolos, de marcas de quem o produz, organiza e nele convive, pois tem significações afetivas e culturais e, por isso, deve ser estudado como parte integrante na formação do discente.

O espaço escolar é parte integrante do currículo, pois também educa e forma. Juntamente com o tempo escolar, orienta e organiza atividades, determina o aceitável e o impróprio, permite e nega determinados comportamentos.

A arquitetura do prédio e seus elementos simbólicos, a localização das escolas nas cidades e sua relação com a ordem urbana, o tipo e a disposição das salas de aulas e de outras instalações, o tipo e a 
disposição das carteiras e dos móveis escolares e os tempos alocados a cada disciplina são aspectos que devem ser considerados como também fazendo parte do currículo escolar, uma vez que correspondem a padrões culturais e pedagógicos que a criança internaliza e aprende (ESCOLANO, 2001, p. 45).

Segundo Escolano (2001), a escola, por meio da sua materialidade, traduz um sistema de valores, tais como os de ordem (por exemplo, a distribuição das séries pelas salas de aula), disciplina (rotinas e formaturas dos alunos e alunas) e vigilância (instalações desenhadas para permitir o controle tanto dos alunos como dos professores). Esses valores são incutidos no currículo oculto dos alunos, a fim de perpetuar a política social controladora dos movimentos e dos costumes. Os espaços educativos estão dotados de significados e transmitem uma importante quantidade de estímulos, conteúdos e valores do chamado currículo oculto, ao mesmo tempo, em que impõem suas leis como organizações disciplinares.

[...] espaços e tempos fazem parte da ordem social escolar. Sendo assim, são sempre pessoais e institucionais, individuais e coletivos, e a busca de delimitá-los, controlá-los, materializando-os em quadros de anos/séries, horários, relógios, campainhas, ou em salas específicas, pátios, carteiras individuais ou duplas, deve ser compreendida como um movimento que teve ou propôs múltiplas trajetórias de institucionalização da escola. Daí, dentre outros aspectos, a sua força educativa e sua centralidade no aparato escolar (ESCOLANO, 2001, p.27).

Os prédios escolares constituíram-se como um importante organizador da vida das crianças e da cidade, onde o traçado arquitetônico das escolas, os elementos simbólicos incorporados à decoração das salas de aula ou às fachadas dos prédios indicavam os padrões e concepções pedagógicas associadas à modernidade, à nacionalidade e ao progresso, estabelecendo, assim, a ideia de pertencimento e de inclusão dos indivíduos. O objetivo principal é que os corpos se tornem acessíveis e disciplinados, obedecendo a uma lógica econômica, “[...] 
na medida em que a disciplina funciona minimizando a força política e maximizando a força útil ou de trabalho" (VEIGA-NETO, 2000, p. 13).

Faria Filho e Vidal (2000) escrevem que a construção de espaços adequados para o ensino, bem como a definição de tempos de aprendizagem, estavam relacionadas não apenas à possibilidade de a escola vir a cumprir as funções sociais que the foram crescentemente delegadas mas, também, à produção da singularidade da instituição escolar e da cultura que lhe é própria. Neste sentido, apontam os espaços e os tempos como parte da ordem social e escolar.

Pinto (2007) enfatiza que o aspecto disciplinar da escola se tornou central, na medida em que passou a ser necessária a educação para todos, “[...] especialmente para as classes tidas como 'perigosas', entre elas, as crianças". E foi nesse contexto que a necessidade de espaços especializados que atendessem a essa demanda foram pensados e pautados em modelos de ordem e mecanismos de coerção.

Pautando-se nos espaços construídos e organizados para as crianças, Lima (1989) denuncia a pobreza e a frieza da construção dos espaços escolares para esse público. Indica que a relação que se estabelece no interior do tempo e do espaço escolar "não é uma relação entre iguais, no sentido de que todos os envolvidos tenham lugar para opinar, para questionar, para descobrir e para aprender", mas, sim, uma relação de "autoridade e disciplina" (LIMA, 1989, p. $58)$.

O espaço escolar não poderia ser outro: desinteressante, frio, padronizado e padronizador, na forma e na organização das salas, fechando as crianças para o mundo, policiando-as, disciplinando-as. Em nome da economia, as soluções são mais comprometidas: a largura das passagens, dos corredores, das escadas reforçam a vontade permanente dos adultos colocarem as crianças em filas; as aberturas, pequenas, para impedir o acesso externo de estranhos servem também para impedir que as crianças se distraiam com o mundo externo (LIMA, 1989, p. 38). 
Em contraponto a essas afirmações, os Parâmetros Básicos de Infraestrutura para Instituições de Educação Infantil (BRASIL, 2006), preconizam que o espaço físico na Educação Infantil deve ser organizado de acordo com as necessidades e características de cada faixa etária. Um dos "indicadores importantes para a definição de práticas educativas de qualidade em instituição de Educação Infantil" (BRASIL, 2006, p. 146) é a qualidade e a quantidade de objetos, brinquedos e móveis presentes no ambiente, que também são considerados poderosos instrumentos de aprendizagem.

Sob essa perspectiva, Barbosa e Horn (2001) propõem que a organização do espaço e tempo na Educação Infantil seja feita a partir da observação daquilo que é objeto de brincadeira das crianças, como estas se desenvolvem, as preferências dessas crianças, bem como o contexto sociocultural no qual a proposta pedagógica está inserida. A perspectiva apresentada é de que o espaço e o tempo são categorias de organização das atividades com as crianças pequenas.

Destacam, ainda, que organizar o cotidiano das crianças da Educação Infantil pressupõe pensar que o estabelecimento de uma sequência básica de atividades diárias é, antes de mais nada, o resultado da leitura que fazemos do nosso grupo de crianças, a partir, principalmente, de suas necessidades. Para as pesquisadoras, no que se refere à organização das atividades no tempo e nas escolas de Educação Infantil, são necessários momentos diferenciados, organizados de acordo com as necessidades biológicas, psicológicas, sociais e históricas das crianças.

Entende-se, assim que são nos espaços educativos que acontecem os rituais: separam-se os alunos por sexo, idade, séries; organizam-se filas e carteiras; estabelecem-se os espaços hierárquicos entre alunos, professores e funcionários. Entretanto, os espaços e os tempos não se definem somente pela 
metragem ou por sua cronologia objetiva, mas pela forma como é experimentado, transformando-se em ambiente de interações e vida. A materialidade do espaço e os sinais de interação humana que nele são percebidos indicam concepções de infância, práticas culturais e corporais, além dos princípios que sustentam o trabalho cotidiano com as crianças.

Portanto, ao recordarmos nossas experiências escolares, podemos perceber que os espaços e os tempos não são estruturas neutras, mas, sim, construções sociais que aprendemos e que condicionam as significações e os modos de educação. Analisar esse espaço e a relação que a criança adquire com o ambiente físico escolar é relevante para entender as práticas corporais infantis. E para Barbosa e Horn (2001), uma organização adequada do espaço e dos materiais disponíveis na escola são fatores decisivos na construção da autonomia intelectual, corporal e social das crianças.

As categorias tempo e espaço estão na base da organização curricular da escola e, por essa razão, são elementos fundantes da dinâmica que orienta as rotinas escolares. Dessa maneira, entender sobre o tempo e espaço da escola é interesse desta pesquisa, para assim compreender como a criança pensa e concebe suas práticas corporais nesses ambientes. 


\section{TRILHAS CONSTRUÍDAS}

Porque são os passos que fazem os caminhos!

Mário Quintana

\subsection{O caminho escolhido: bases teóricas e metodológicas}

Este capítulo busca constituir os elementos teóricos e metodológicos que resultaram no desenho metodológico da pesquisa. Este estudo implicou em uma pesquisa de campo com elementos da abordagem qualitativa. A investigação qualitativa busca entender o fenômeno em sua totalidade e realidade. A pesquisa qualitativa preocupa-se, portanto, com aspectos da realidade que não podem ser quantificados, centrando-se na compreensão e explicação da dinâmica das relações sociais. Para Minayo (2010), a pesquisa qualitativa compreende um universo de significados, motivos, aspirações, crenças, valores e atitudes, o que corresponde a um espaço mais profundo das relações, dos processos e dos fenômenos que não podem ser reduzidos à operacionalização de variáveis.

Neste sentido, esta pesquisa potencializou a autonomia e a efetiva participação das crianças. Em estudos relacionados com crianças, Javeau (2005) prioriza o método qualitativo por conta da forma específica com que as crianças interagem e exteriorizam as suas representações. Segundo esse paradigma, o autor explica que as crianças devem ser consideradas uma população com pleno direito científico. Assim relata:

[...] se trata antes de tudo de pôr em evidência as significações que as crianças atribuem aos diversos componentes dos estilos de vida que levam tanto na perspectiva da contribuição bruta de uma cultura específica quanto na relação desta com os diversos processos de socialização em ação, dos quais um grande número surge na realidade da auto-socialização, qualquer que seja o quadro: família, escola, rua, terreno vago, colônia de férias, etc. (JAVEAU, 2005, p. 385).

Dessa maneira, Martins Filho (2011) destaca que pesquisas cuja ênfase na escuta das vozes das crianças permitem obter, em primeira mão, informações e 
opiniões sobre seu mundo educacional, social e cultural. Isso significa interagir, analisar e contextualizar historicamente as falas captadas das crianças. As pesquisas que têm as crianças como objeto de estudo em suas múltiplas dimensões buscam romper com a perspectiva do olhar "adultocêntrico" ${ }^{1}$ sobre o universo infantil, ao mesmo tempo que valorizam a produção cultural das crianças para além do brincar. Enfim, significa ultrapassar a ideia da modernidade de pesquisar criança isoladamente, de forma asséptica, alheia a sua condição social.

Visto o exposto, o estudo e a inserção no contexto das práticas corporais das crianças nos tempos e espaços escolares se tornaram foco de análise. Compartilha-se, portanto, com Pinto e Sarmento (1997, p. 65), a ideia de que as crianças são sujeitos conscientes de seus sentimentos, ideias, desejos e expectativas, sendo capazes de expressá-los “[...] desde que haja quem os queira escutar e ter em conta”. Foi com essa crença que me aventurei neste caminho, tendo as crianças como foco de meu olhar de pesquisadora adulta, na intenção de traduzir os modos de ser criança, escutando-as e levando-as em conta, consciente do desafio que tal empreitada se apresentou.

Nesse horizonte, Carvalho e Müller (2010) destacam ser fundamental considerar as questões éticas nas pesquisas com crianças. Trilhando este percurso, é importante esclarecer que todos os procedimentos éticos em relação à inserção ao campo de pesquisa foram devidamente realizados, o que incluiu a confecção de um Termo de Consentimento Livre e Esclarecido (TCLE) e um Termo de Assentimento (TALE) que em reunião conjunta com crianças e responsáveis foram assinados por todos, confirmando assim o protagonismo de sua participação. Os termos e outros documentos complementares foram

\footnotetext{
${ }^{1}$ Nesse caso o modelo é o adulto e tudo passa a ser visto e sentido segundo a ótica do adulto, ele é o centro. (GOBBI, 2002, p. 26).
} 
submetidos à rigorosa análise e aprovados pelo Comitê de Ética em Pesquisa da Faculdade de Ciências da Saúde, da Universidade de Brasília.

A reunião com a crianças, apesar de acontecer com a presença dos responsáveis, teve suas especificidades. Ficamos reunidos sentados em círculo no chão da sala e em um clima bem descontraído conversamos sobre o que eu faria em todo o tempo que estivesse na escola com elas. Muitos questionamentos surgiram, especialmente, se a "tia" não estaria mais com elas e se eu seria "a nova tia". Esse primeiro contato foi muito importante para que a pesquisadora fosse aceita e vista de maneira diferente de uma professora. Já que ser vista como um agente da escola poderia influenciar nas ações das crianças durante a minha presença.

$\mathrm{Na}$ intenção de responder ao que o estudo se propõe, a saber, identificar e analisar as práticas corporais de crianças nos tempos e espaços da escola, foram utilizadas, nesta pesquisa qualitativa, técnicas e instrumentos que permitiram a real participação da pesquisadora com os sujeitos elencados, as crianças. As técnicas utilizadas compreenderam observação participante, produção de desenhos e conversas informais com as crianças.

A observação participante, conforme Bogdan e Biklen (1994), permite contato direto do pesquisador com o fenômeno observado. Este instrumento metodológico deve acompanhar diferentes momentos da vida em curso no espaço e tempo da instituição pesquisada, sendo que, nos primeiros dias, o investigador fica um pouco "de fora", aguardando que o observem e o aceitem e na medida em que as relações se desencadeiam a participação será mais efetiva. Este recurso metodológico tem sido ponto forte nas pesquisas com crianças, conforme descreve Martins Filho (2011, p. 93):

A observação participante possibilitará o acesso dos adultos ao que as crianças pensam, fazem, sabem, falam e de como vivem, esmiuçando suas peculiaridades e as particularidades desse grupo geracional. Esta 
forma aberta e desprovida de amarras poderá aprofundar as heterogeneidades das infâncias.

Aconteceu assim, a nossa pesquisa, num recorte temporal aproximadamente de três meses, abrangendo os meses de março a junho do ano de 2014. Houve, neste período, um acompanhamento diário de observação da turma. Deste modo, pode-se assistir com maior proximidade a realidade do seu cotidiano. "Neste momento as crianças podem estabelecer laços de confiança e empatia com o pesquisador, e para se sentirem à vontade para responder às demandas da pesquisa" (CARVALHO; MÜLLER, 2010, p. 73).

As observações foram registradas em diário de campo, construído de acordo com os fundamentos explicitados por Bogdan e Biklen (1994). Segundo esses autores, o diário de campo é o instrumento adequado para uma observação participante, que se constitui da observação, descrição e análise das atividades rotineiras das crianças. Ainda segundo esses autores, o conteúdo dessas observações deve conter uma parte descritiva, que compreende um registro detalhado do que ocorre e outra reflexiva que inclua as inquietações pessoais do pesquisador durante a fase da coleta. Esse instrumento permitiu uma atuação dialógica da pesquisadora no modo como os sujeitos participam de suas atividades diárias em seus tempos e espaços escolares.

Locais comuns à rotina escolar foram cenários para as observações, vislumbrando os momentos do cotidiano dos sujeitos envolvidos, tais como: a entrada, a sala de aula, a hora do lance, o momento do parque e a saída. $\mathrm{O}$ objeto utilizado para o registro das observações foi um caderno pequeno que servia para anotar pequenos trechos e pontos relevantes das ações das crianças. A descrição detalhada ocorria em computador no final de cada dia em campo. Essa maneira de portar-se em campo permitiu melhor interação com os sujeitos da pesquisa, 
pois me viam como um participante de suas rotinas e não um adulto em um canto da sala anotando tudo que acontecia.

A produção de desenhos e conversas informais visaram compor a triangulação dos instrumentos de pesquisa, bem como potencializar as crianças como produtoras dos dados da pesquisa. Gobbi (2002) estabelece que os desenhos podem ser compreendidos como fontes documentais que nos informam sobre as crianças, sobre a infância em diferentes contextos sociais, históricos e culturais, corroborando com o intuito de permitir às crianças expressarem suas percepções em papel. Isto posto, os desenhos têm um lugar central, neste estudo, como produção simbólica e forma de expressão e interpretação do mundo pelas crianças. Enfim, o desenho representa uma possibilidade de reconstruir os tempos e espaços, assim como as práticas corporais por elas vivenciadas. Pretendeu-se, assim, trazer as crianças como atores principais da pesquisa, permitindo que por meio de seus grafismos elas pudessem nos dizer verdadeiramente como fazem uso dos tempoes e espaços propostos pela estrutura escolar. Gomes (2009) destaca que o desenho infantil é uma linguagem original, própria da infância, usada para expressar o pensamento, as sensações corporais, os sentimentos, os desejos e as emoções. Nesse contexto, Gobbi (2002) relata que as crianças pequenas são portadoras e criadoras de cultura, desenhistas, falantes, sujeitos de sua história e cujas produções devem ser conhecidas, valorizadas e respeitadas.

No tocante a conversas informais, as mesmas foram realizadas ao longo de todo período em campo e em especial destaque para o dia da produção dos desenhos. Essas foram gravadas e depois transcritas e anexadas em cada desenho correspondente. Pesquisadores como Martins Filho (2011), afirmam que, para além de simplesmente desenhar, é necessário interpretar os desenhos a partir dos olhares e falas de seus autores. Nesse sentido, as conversas com as crianças 
foram fundamentais para entender e dar significado ao que elas desenharam. Sendo o desenho fonte documental, como explica Gobbi (2002), seu sentido, então, não se desvenda separado da fala de seus autores. Com isso, Carvalho e Müller (2010) fortalecem a ideia de que conjugar dados visuais a dados verbais pode contribuir para a obtenção de informações peculiares sobre os fenômenos estudados. Entendem, também, que ouvir as crianças representa distanciar-se de juízos de valores e aproximar-se da realidade que deseja descobrir.

Para a produção dos desenhos pedimos às crianças dois registros a partir de perguntas relacionadas aos objetivos desta pesquisa. Para o primeiro desenho foi proposta a pergunta: "na escola, qual a sua brincadeira preferida?" Neste caso, as crianças expuseram a brincadeira ou brincadeiras que mais gostavam de realizar na escola e por meio dessa produção identificamos os tempos e espaços que as crianças consideravam disponíveis às práticas corporais. O segundo tema foi pautado na pergunta: “o que mais gosto de fazer na escola e em que lugar?" e "o que menos gosto de fazer na escola e em que lugar?". Neste item identificouse aspectos referentes às ações das crianças nesses lugares assinalados anteriormente por elas, ou seja, especificar práticas corporais que "mais gostam" e que "menos gostam".

Os desenhos foram realizados na sala de aula e coletados após um longo período de imersão em campo e em combinação aos planos de aula da professora regente. Para a primeira produção, a cada criança foi entregue uma folha de papel A4 branca e para o segundo, folha A4 colorida. Materiais como canetinhas, lápis de cor e giz de cera também foram disponibilizados. $\mathrm{O}$ primeiro deles ocorreu após quarenta dias de observação, houve a participação de 26 crianças e o segundo dez dias depois da primeira produção teve a presença de 23 crianças. Nos dois dias reservados para os desenhos não contamos com a presença de 
todas as crianças e por não haver outra oportunidade em decorrência do planejamento escolar, algumas crianças ficaram sem expressar os seus traçados.

As conversas informais, no dia da criação dos desenhos, aconteceram em grupos durante a produção e individualmente logo após a conclusão dos trabalhos. Durante as conversas, solicitou-se que cada criança escolhesse um nome fictício para figurar no presente estudo. Sugeriu-se a escolha de um nome que elas gostassem ou de alguém que elas admiravam. Ressalta-se que essa não foi uma decisão arbitrária e sim mais uma oportunidade de evidenciar as crianças como sujeitos principais dessa pesquisa. As conversas individuais foram gravadas com o auxílio de um aparelho celular. Para essas conversas além de perguntas referentes ao desenho perguntou-se também se elas gostavam de ir para escola, se às vezes elas tinham vontade de sair de sala e o que fazer, em que momento elas podiam brincar e se brincavam em sala de aula, além do que elas achavam da sala de aula e se queriam que algo fosse diferente na escola. Essas perguntas surgiram com o decorrer das conversas e portanto só foram sistematizadas para algumas crianças. Porém, foram importantes na organização das categorias de análise.

Para análise dos dados, considerou-se os preceitos de Bogdan e Biklen (1994), que destacam que a análise de dados é caracterizada como um procedimento de busca e organização sistemática dos instrumentos metodológicos. Neste caso, diário de campo, produção de desenhos e conversas informais, com o objetivo de aumentar a própria compreensão desses mesmos materiais e permitir apresentar aos outros aquilo que encontrou. Neste aspecto, a tarefa de análise, implicou em organização dos dados coletados, catalogando-os em partes na busca de encontrar categorias relevantes e, em seguida, revisandoas à procura de correlacionar as inferências. 
A categorização foi elaborada por meio de leitura minuciosa de todas as anotações realizadas e materiais produzidos pelas crianças. Desta maneira, estabeleceu-se categorias prévias, conforme a frequência e regularidade apresentada nos dados recolhidos. Destaca-se, também, que foram definidas posteriormente as visitas ao campo de pesquisa. Esse processo foi recorrido algumas vezes, tomando-se o cuidado de retomar constantemente a leitura para a viabilidade das categorias. Após defini-las, fez-se releitura dos dados, utilizandose de marcadores coloridos e numeração alfabética indicando o grupo pertencente.

Salienta-se que na observação e catalogação dos dados, observou-se a presença de diversos aspectos. Portanto, as categorias de análise partiram de características evidenciadas nas produções gráficas e observações. De acordo com Lüdke e André (1986), a análise não deve estar restrita ao que foi encontrado no material recolhido e ao aporte teórico. É preciso visualizar nas entrelinhas leituras que venham a desvendar mensagens implícitas ou silenciadas.

Desta maneira, evidenciou-se que a categoria denominada "Práticas coporais na escola" que apresenta a descrição dos tempos e espaços do cotidiano escolar e das mediações culturais que permearam o universo da cultural lúdica daquelas crianças. E "A brincadeira como prática corporal essencial” revelou-se como categoria de análise por esse objeto constar em todas as produções gráficas realizadas pelas crianças.

\subsection{De onde estamos falando}

\subsubsection{Localizando o tempo e o espaço: o campo de pesquisa}

O Centro de Educação Infantil (CEI), lócus dessa pesquisa, se encontra na Região Administrativa do Riacho Fundo II (RA-XXI), que fica a $30 \mathrm{~km}$ de 
distância da cidade de Brasília, Distrito Federal. A escola como um todo, ocupa uma área de aproximadamente $5.000 \mathrm{~m}^{2}$, sendo a construção do prédio de apenas um pavimento, com duas entradas: um acesso para carros e outro acesso para os pedestres.

O CEI está vinculado à Diretoria Regional de Ensino (DRE) do Núcleo Bandeirante. Foi inaugurado aos onze dias de dezembro de dois mil e três. Sua criação teve por principal objetivo suprir a necessidade da comunidade local de uma Unidade Pública de Ensino que atendesse à Educação Infantil. É uma Instituição pertencente à Secretaria de Educação do Distrito Federal (SEE-DF), mantida por verbas do Governo Federal - Fundo Nacional de Desenvolvimento da Educação (FNDE) e do Governo do Distrito Federal (GDF), através do Programa de Descentralização dos Recursos Financeiros (PDRF). A escola conta também com o Conselho Escolar, que é formado por pais ou responsáveis dos estudantes, representante de auxiliares da educação e professores. É este grupo que assume o papel de tomada de decisões quanto à captação de recursos financeiros bem como a aplicação do mesmo.

A equipe de funcionários envolvida nessa Instituição de Ensino abrange diretor, vice-diretor, apoio de direção, chefe de secretaria, apoio de secretaria, apoio administrativo, supervisor pedagógico, quatro coordenadores pedagógicos, trinta e dois professores regentes, uma professora para a sala de leitura, um orientador educacional, um professor que atende na sala de recursos e um psicólogo itinerante que atua na equipe especializada de apoio à aprendizagem, onze auxiliares de educação trabalhando na conservação, limpeza, copa e cozinha, quatro agentes de vigilância e dois porteiros. 


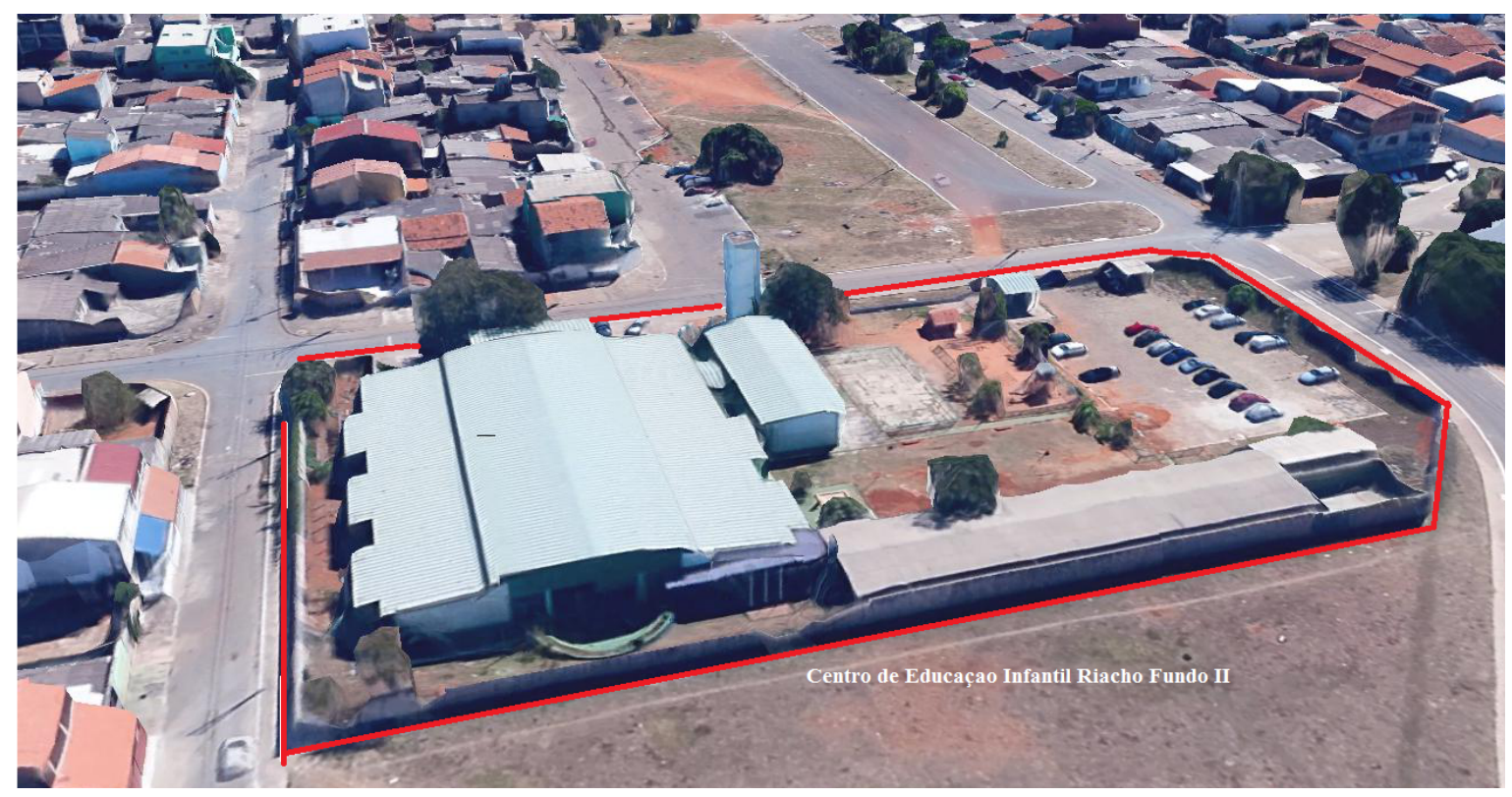

Figura 1: A escola. ${ }^{2}$

Fonte: Google (2015)

De acordo com os Parâmetros Básicos de Infraestrutura para Instituições de Educação Infantil (BRASIL, 2006), os espaços físicos devem apresentar uma estrutura que reconheçam a criança como sujeito do processo educacional e como principal usuário do ambiente educacional. A estrutura física da instituição elencada para a pesquisa se apresenta da seguinte forma: quinze salas de aula, três banheiros infantis, cinco banheiros para uso de adultos, uma sala para funcionamento da direção, uma sala para o serviço de orientação educacional e equipe especializada de apoio à aprendizagem, uma sala para funcionamento da secretaria e reprografia, uma sala para o arquivo, uma sala de recursos, uma sala de leitura e vídeo, uma sala de informática, uma sala para o projeto interventivo, uma sala para o projeto arte e movimento, uma sala de material didático, uma cantina, uma sala para uso dos servidores, dois depósitos, uma área com ducha fria, um parque com brinquedos e uma casinha de bonecas e uma quadra de esporte descoberta.

\footnotetext{
${ }^{2}$ Foto área do Centro de Educação Infantil Riacho Fundo II.
} 
A área interna do prédio tem um pátio de circulação que permite o acesso a todas as salas de aula e às salas da administração. Logo na entrada, à direita do portão, tem uma mesa com o porteiro que recepciona as crianças na entrada de cada turno. Sua área física é pequena e concentra toda a movimentação da escola, pois é por ele que se chega aos outros corredores, salas, cantina, parque e estacionamento. Na parte administrativa, as salas da secretaria, da Diretora e das professoras, que é a mesma para as reuniões e coordenações fica uma ao lado da outra, sendo bastante pequenas. A mecanografia (onde são reproduzidas as tarefas) situa-se no final em uma ante sala da secretaria. Para melhor visualização da área interna da escola segue abaixo (Figura 2) planta baixa do CEI.

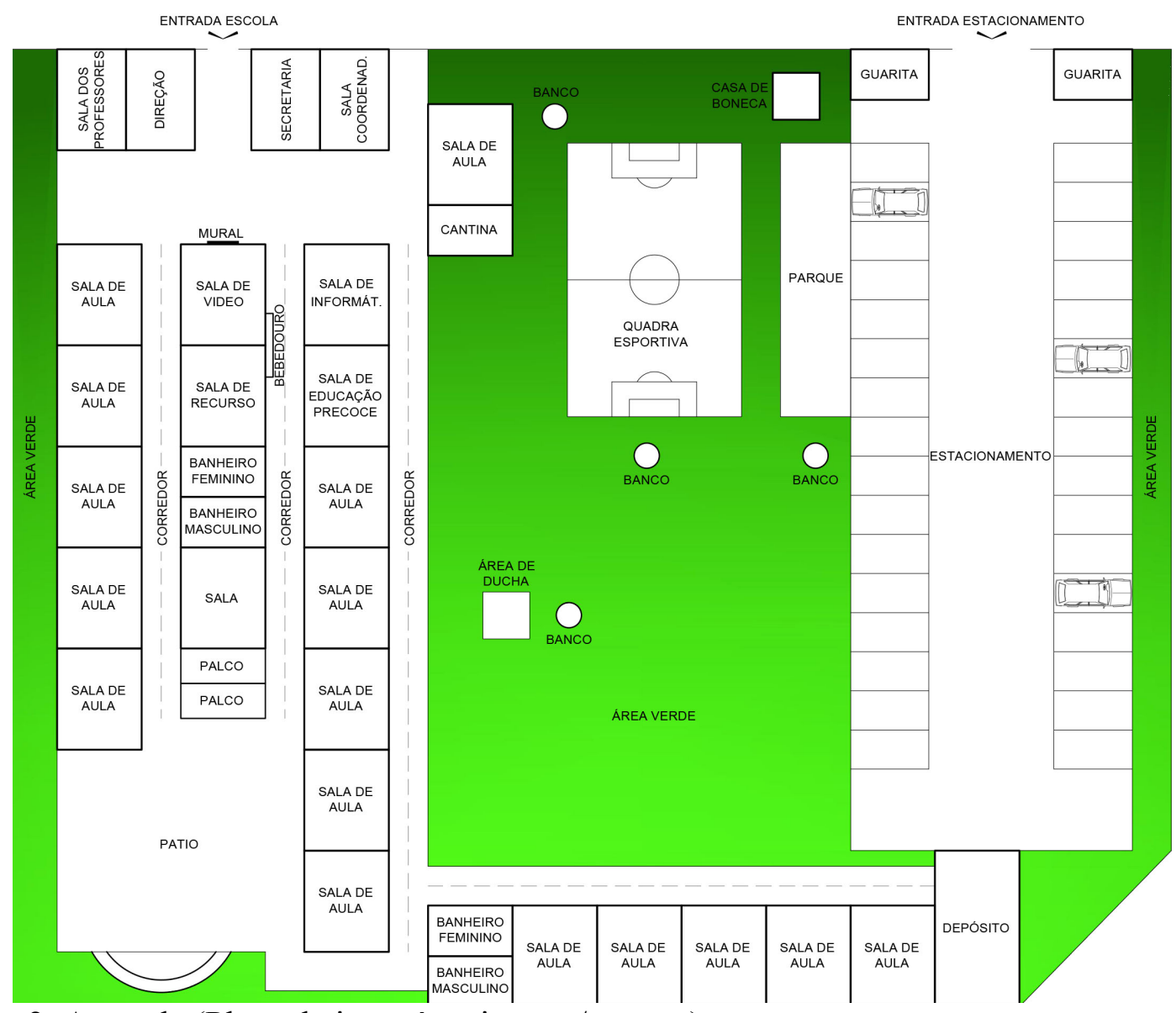

Figura 2: A escola (Planta baixa - área interna/externa) Fonte: Da autora 
Das quize salas de aula, dez ficam em torno do pátio central, umas ao lado das outras, formando uma espécie de anel. Essa disposição remete muito ao panóptico descrito por Foucault (2007), que funciona como um mecanismo de observação e pode construir-se em um aparelho de controle dos corpos e disciplinarização humana.

O panóptico, de acordo com Foucault (2007), consiste em um edifício circular com um pátio no centro e pequenas salas ao seu redor. No centro do pátio, existe uma torre de onde poderiam ser observadas todas as salas e, ao mesmo tempo, de todas as salas se viam as torres. Assim, quem estivesse na sala teria a sensação de estar sendo observado a todo o momento, sem necessariamente ter a certeza de quando isto estaria acontecendo. Este modelo arquitetônico poderia ser usado em hospitais, prisões, escolas, asilos etc.

Hoje, o mais interessante deste modelo problematizado por Foucault é a alusão da idéia de vigilância constante, embora não exista o panóptico (edifício), existe a sua essência (a vigilância). Somos vigiados por câmeras, pelos outros nas relações sociais, por exemplo, no caso da escola o professor vigia as crianças, que por sua vez vigiam umas as outras, porém, o professor também é vigiado pela coordenação e assim por diante.

No CEI, para circulação de um corredor a outro, quase sempre é preciso passar em frente às salas do corpo diretivo da escola. Esse pátio central também permite acesso ao prédio anexo, localizado em frente ao parque e onde se situam os banheiros das crianças, os bebedouros de água e mais cinco salas de aulas.

Com essa estrutura, atualmente o CEI atende alunos da Educação Infantil 4 a 5 anos, $1^{\circ}$ e $2^{\circ}$ Anos do Ensino Fundamental, Educação Especial (Transtornos Globais do Desenvolvimento (TGD) e Deficiência Múltipla (DMu) e Educação Precoce. Para o ano de 2014, estiveram matriculados 679 crianças 
distribuídas em dois turnos, matutino, com atividades no horário de $07 \mathrm{~h} 30 \mathrm{~min}$ às 12h30min, e vespertino, com atividades no horário de 13h00min às $18 \mathrm{~h} 00 \mathrm{~min}$.

\subsubsection{O campo em contexto: organização do trabalho pedagógico}

O trabalho pedagógico é organizado a partir do planejamento anual, tendo referência no Projeto Político Pedagógico (PPP/2014) da instituição de ensino analisada. De acordo com o referido Projeto ${ }^{3}$, o currículo da Educação Infantil se estrutura em âmbito de experiências e eixos de trabalho, propiciando o desenvolvimento de competências e habilidades: Formação pessoal e social- eixo de trabalho: Identidade e Autonomia; e Conhecimento de Mundo- eixos de trabalho: Movimento, Artes Visuais, Música, Linguagem Oral e Escrita, Natureza e Sociedade e Conhecimento Lógico-Matemático, tudo isso privilegiando um ambiente lúdico e de letramento. Ainda com base no PPP/2014, estabelece-se que o currículo do Ensino Fundamental de 9 anos Anos Iniciais ( $1^{\circ}$ ao $5^{\circ}$ ano), aponta para a aquisição de habilidades e competências dos alunos, pautado em um grande eixo integrador: Letramento e Diversidade.

Em seu PPP/2014, o CEI do Riacho Fundo II definiu como tema central para as atividades bimestrais e diárias: "Pequeno Grande Cidadão: Valorizando a Vida". O objetivo principal dessa temática é promover uma educação transformadora voltada para formação da ética e da cidadania, embasada na construção e aprimoramento de valores, dentro de uma cultura de paz, respeitando o contexto sociocultural. Neste ínterim, o valor respeito foi trabalhado no $1^{\circ}$ bimestre, o amor no $2^{\circ}$ bimestre, a honestidade no $3^{\circ}$ bimestre $\mathrm{e}$ a paz no $4^{\circ}$ bimestre.

\footnotetext{
${ }^{3}$ Documento que define a identidade da escola e indica caminhos para ensinar com qualidade.
} 
Os valores mencionados serão trabalhados no cotidiano escolar a partir de atividades e projetos desenvolvidos ao longo do ano letivo. As atividades permanentes do CEI compreendem: festa de acolhimento, festa da família, semana temática (dia da pessoa com deficiência), semana da criança, feira cultural (científico-literária), bailinho do BIA (Bloco Inicial de Alfabetização) (despedida dos alunos do $2^{\circ}$ Ano), momento cívico (culminância dos valores: respeito, amor, honestidade e paz), acolhida diária no pátio, passeios culturais (cinema, teatro, parque, circo, etc.) e confraternização de Natal (cantata).

Os projetos específicos para o Ensino Fundamental são: o "Literário", desenvolvido pelas turmas de $1^{\circ}$ e $2^{\circ}$ anos e o "Interventivo", necessário ao atendimento dos alunos em processo de alfabetização e em defasagem de aprendizagem e/ou idade-série, além de projetos relacionados a outros segmentos da escola como os projetos "João e Maria" e "Correio da Amizade", ambos organizados pela sala de leitura e "Escola de Pais e Todos pela Paz", organizados pelo SOE, além do projeto "Informática".

Percebe-se que a escola busca a emancipação de suas crianças por meio de suas atividades rotineiras e projetos desenvolvidos anualmente. Considera-se, portanto, o esforço da instituição em realizar um trabalho interdisciplinar que pretende não fragmentar os saberes.

Desta forma, optar em realizar o estudo nesta instituição de ensino ocorreu por esta demonstrar interesse em participar de pesquisas, além de apresentar em seu PPP atividades que protagonizassem a criança em todos os aspectos: cognitivo, social e motor, bem como a facilidade de aceitação por parte de todo corpo diretivo e da professora regente devido relações de amizade entre a pesquisadora e uma professora do quadro efetivo da escola. Para Bogdan e Biklen (1994), esta relação aprazível entre sujeitos do campo e o pesquisador é essencial no processo do estudo, uma vez que havendo um diálogo entre as 
partes consegue-se obter um maior acesso às informações, desta maneira enriquecer o estudo.

\subsection{De quem estamos falando: os protagonistas}

Para o desenvolvimento do estudo elencou-se uma turma de $1^{\circ}$ ano do Ensino Fundamental. Nessa turma estavam matriculadas 27 crianças, dentre as quais 7 meninas. A escolha da turma ocorreu após contato com a direção do CEI e a explicação dos objetivos da pesquisa, bem como dos instrumentos de coletas de dados. De acordo com a equipe gestora seria importante realizar a pesquisa na presença de uma professora dinâmica, participativa e, sobretudo, que compreendesse e valorizasse pesquisas dessa natureza, além de utilizar em sua prática pedagógica a ferramenta de produção de desenhos. Destaco que este aspecto tornou-se colaborativo na aquisição dos instrumentos escolhidos para esta pesquisa.

Por meio desses critérios a escolha da turma foi consequente à escolha da professora. Chegou-se, então ao $1^{\circ}$ ano "G", uma turma constituída de crianças entre seis e sete anos de idade. Apesar da pouca idade as crianças atenderam as expectativas em relação as produções gráficas e oralidade. Visto que não observamos a qualidade artística dos desenhos e sim o conteúdo que neles constavam. As falas das crianças, suas brincadeiras, desenhos, e muitas vezes até mesmo seu silêncio, nos revelaram muito de suas percepções em relação ao mundo que as cercam.

As crianças dessa turma, em sua maioria, são provenientes de turmas da educação infantil $\left(2^{\circ}\right.$ período $)$ da própria instituição de ensino e residentes na comunidade local, portanto por residirem próximas à escola não necessitam utilizar transporte para se deslocarem até aquele espaço, mas muitas são acompanhadas diariamente por pais ou parentes próximos no percurso até o 
mesmo. Esse trajeto é realizado em sua maioria a pé, mas observamos a presença do uso do automóvel particular e também da bicicleta. Algumas, porém, fazem o uso de transporte escolar, devido a indisponibilidade de um adulto familiar em acompanhá-las.

Todas as crianças participam de famílias de trabalhadores, com realidades sociais e culturais e com cotidianos organizados de formas bem parecidas. As profissões dos pais ou responsáveis, segundo questionário ${ }^{4}$ respondido com os mesmos, eram diversas: motoboy, atendente, auxiliar de limpeza, trabalhador autônomo, agente de portaria, policial, motorista, vendedor, balconista, backoffice de call center, auxiliar de serviços gerais e encarregado da construção civil. Entre as mães, as profissões variavam entre dona de casa, cabeleireira, secretária e auxiliar de limpeza.

A maior tecnologia a que essas crianças têm acesso é a televisão, seguida do computador e aparelho de DVD. A grande maioria da turma, independente da condição financeira da família, elege como principal veículo de informação e diversão presente em suas casas a televisão. A presença deste veículo de informação é constante junto às crianças nos períodos em que estão em casa, apesar de destacarem que aliavam momentos de brincadeiras com momentos em que assistiam a TV, jogos de vídeogame e navegação pela internet. Os programas mais assistidos eram desenhos animados transmitidos em programas infantis matinais e novelas. Para atividades pedagógicas observa-se que o computador ainda é um instrumento tecnológico presente e utilizado pelas crianças apenas na escola.

Entre as crianças envolvidas com a pesquisa, nenhuma vivencia situações familiares de violência ou que as obriguem a se envolver com o trabalho

\footnotetext{
${ }^{4}$ As informações obtidas derivam de um questionário socioeconômico aplicado pela professora regente em conjunto com a direção da escola com o objetivo de traçar o perfil das famílias participantes da escola.
} 
precoce, mas um dos meninos que, entre as diferentes situações familiares experienciadas pelas crianças que compunham o grupo envolvido na pesquisa, participa de uma das realidades de maior carência econômica, manifesta seguidamente o desejo de crescer logo para poder trabalhar e relata não gostar de retornar para casa, pois não há espaços para brincadeiras (DIÁRIO DE CAMPO, 30/04/2014, p. 37).

Para melhor compreender o tempo e espaço de cada indivíduo, procurouse colocar, tabela em anexos, os caracteres mais marcantes de cada uma das crianças envolvidas, com breves descrições dos elementos visíveis obtidos por meio das observações.

É importante revelar que nessa turma as relações construídas em sala foram compartilhadas por um cotidiano coletivo cheio de harmonia, brincadeiras e criatividade. O tempo que estas crianças passavam juntas estabelecia a construção do modo de ser delas próprias. $\mathrm{O}$ ambiente de convívio demonstrouse propício para imaginações em virtude da presença de painéis coloridos produzidos pela professroa e alguns cartazes confeccionados pelas próprias crianças, além de muitas revistinhas em quadrinhos e livros, bem como sempre a mão massinhas de modelar e lápis para colorir.

São muitos, ricos e distintos os lugares sociais dos quais os sujeitos participam, narram, se apropriam de suas histórias e partilham da construção da história social e cultural. Nas experiências cotidianas, vê-se tecida uma vida coletiva, uma trajetória que consolida discursos e significados sociais. São falas, ações, relações, conceitos e preconceitos que, dia-a-dia, se alimentam, se desconstroem e podem ser reelaborados. Por conta disso, diversas são as experiências que vivenciam, variados são os tratamentos que recebem a partir de sua condição de criança e desiguais são as formas de organização de suas rotinas diárias. 
Observando os aspectos mencionados destaca-se de forma condensada a rotina vivenciada pelas crianças participantes da pesquisa. Em seguida, a partir da interlocução das técnicas de pesquisa, do referencial teórico de base e sobretudo, por meio da realidade vivenciada esmiuçamos o diálogo encontrado nesses tempos e espaços.

A rotina escolar dessa turma era estabelecida da seguinte maneira:

Quadro 1: Rotinas institucionalizadas nos tempos e espaços do $1^{\circ}$ ano "G".

\begin{tabular}{|c|l|l|}
\hline Tempos & \multicolumn{1}{|c|}{ Espaços } & \multicolumn{1}{c|}{ O Que Acontece } \\
\hline 12:50-13:00 & Frente da escola & $\begin{array}{l}\text { As crianças ficam esperando a abertura do portão. } \\
\text { Umas com seus pais conversando; outras sozinhas } \\
\text { encostadas no muro ou conversando com um } \\
\text { colega. Não há muita movimentação corporal. }\end{array}$ \\
\hline 13:00-13:15 & $\begin{array}{l}\text { Entrada em sala de } \\
\text { aula. }\end{array}$ & $\begin{array}{l}\text { Aos poucos as crianças chegam, escolhem um } \\
\text { lugar; pegam um brinquedo; conversam entre si; } \\
\text { conversam com a professora; caminham entre as } \\
\text { mesas e cadeiras; enfim, movimentam-se no } \\
\text { espaço da sala de aula de maneira livre e } \\
\text { consentida. Exceto, quando brincam no espaço em } \\
\text { frente ao quadro branco. }\end{array}$ \\
\hline $13: 15$ & Sala de aula & $\begin{array}{l}\text { Professora chama todos aos seus lugares e com } \\
\text { eles pronuncia as atividades do dia. A rotina é } \\
\text { materializada no quadro desta maneira: } \\
\text { Oração } \\
\text { Rotina } \\
\text { Atividade } \\
\text { Lanche } \\
\text { Atividade } \\
\text { Recreação } \\
\text { Atividade } \\
\text { Saída }\end{array}$ \\
\hline $13: 30$ & Sala de aula & $\begin{array}{l}\text { Oração. Nesse momento a professora e as crianças } \\
\text { agradecem por estarem na escola, agradecem pela } \\
\text { família e também pela vida. }\end{array}$ \\
\hline & & \begin{tabular}{l}
$\mid c$ \\
\hline
\end{tabular} \\
\hline & & \\
\hline
\end{tabular}




\begin{tabular}{|c|l|l|}
\hline $13: 40$ & Sala de aula & $\begin{array}{l}\text { Rotina. É realizado o abecedário completo. } \\
\text { Separação silábica. Sistema numeral, calendário. } \\
\text { Contagem das crianças presentes. } \\
\text { Nesse momento observa-se atividades com } \\
\text { objetivo de alfabetização. }\end{array}$ \\
\hline $14: 00$ & $\begin{array}{l}\text { Sala de informática e } \\
\text { sala de vídeo/leitura. }\end{array}$ & $\begin{array}{l}\text { Em cada dia da semana é proposta uma atividade a } \\
\text { partir do projetos desenvolvidos pela escola. }\end{array}$ \\
\hline $15: 00$ & Sala de aula & Momento do lanche. \\
\hline $15: 30$ & Sala de aula & $\begin{array}{l}\text { Atividade de ensino aos conteúdos de português, } \\
\text { matemática, história, ciências, geografia e artes. }\end{array}$ \\
\hline $16: 30$ & $\begin{array}{l}\text { Parque, quadra de } \\
\text { esportes ou pátio }\end{array}$ & $\begin{array}{l}\text { Momento de recreação das crianças, que ocorre de } \\
\text { maneira livre, sem planejamento pedagógico. }\end{array}$ \\
\hline $17: 00$ & Sala de aula & $\begin{array}{l}\text { Atividade de ensino de conteúdos referentes a } \\
\text { português, matemática, história, ciências, geografia } \\
\text { e artes. }\end{array}$ \\
\hline
\end{tabular}

Fonte: Da autora. 


\section{PRÁTICAS CORPORAIS NA ESCOLA}

Neste capítulo, concebe-se como ponto de partida as relações de pesquisa estabelecidas no cotidiano da escola: registrou-se e sistematizou-se os diferentes tempos e espaços que emergem com sentido pedagógico e mediações culturais. Apresenta-se uma análise que enfoca a educação que atravessa os corpos dos sujeitos, a qual instaura significados que absorvem sentido em um contexto tanto escolar específico quanto cultural mais amplo.

\subsection{Tempos e espaços}

Para registrar as práticas corporais das crianças em tempos e espaços escolares, destacamos a descrição pautada na maneira como as crianças e seus corpos se relacionaram nesses ambientes. Assinalo que o corpo aparece como um objeto extremamente valorizado, focalizado e solicitado na sociedade e na cultura contemporâneas. Os corpos dos sujeitos evidenciam signos de pertencimento e exclusão, produção e consumo, controle e autonomia. Nessa perspectiva, Soares (2001) destaca que é preciso sinalizar uma percepção de que desde a infância incide uma educação que, como processo histórico, investiu na retidão e buscou conter os excessos do corpo. Os sujeitos e seus corpos individualizados e higienizados, civilizados e desenraizados - foram conduzidos para um território oficial regulado por uma ideia de utilidade e controle cuja intervenção pedagógica se incumbiu de redesenhar seu desenvolvimento e conduta, seus gestos e suas instituições, promovendo o que pode ser denominado uma educação dos corpos.

As práticas corporais são, considerando esse contexto mais amplo de educação dos corpos, todos os gestos, as expressões, as brincadeiras, os jogos, as danças e os esportes, capazes de serem representados pela cultura infantil. 
Identificou-se, assim, os tempos e espaços da rotina, do portão de entrada, da sala de aula, do pátio ao corredor, da quadra, do parque e da saída.

\subsubsection{Rotina}

Denomina-se rotina a distribuição cronológica do tempo por meio de atividades coletivas que são realizadas pelas crianças e professoras ao longo de um dia escolar. Após a entrada, as crianças se reunem com as professoras em suas salas, escolhem um lugar para sentar-se, pegam um brinquedo, conversam entre si, interagem com a professora, caminham entre as mesas e cadeiras. Enfim, movimentam-se no espaço da sala de aula de maneira livre e consentida.

São então iniciadas as atividades planejadas para o dia. Diariamente é realizada uma oração de agradecimento pelo dia. Durante a oração, as crianças pediam, encorajadas pela professora, para serem boas e comportadas, inteligentes e obedientes. Como parte da rotina também é realizada a leitura do abecedário e silabário, do sistema numeral, do calendário e contagem das crianças presentes. Observou-se que todos os signos que constituem esse momento, bem como a organização do espaço em mesas e cadeiras enfileiradas, contribuem na formação da prontidão necessária à alfabetização.

Com efeito, como parte da rotina, a cada dia é proposta uma atividade. $\mathrm{Na}$ segunda-feira as crianças participavam de aulas na sala de informática; na terçafeira e na quarta-feira elas ouviam uma história ou assistiam a um vídeo, e na quinta-feira participavam da hora cívica e apresentações artísticas e culturais realizadas no pátio. A sexta-feira era o dia mais esperado pelas crianças, pois acontecia o dia do brinquedo. Todas eram estimuladas e orientadas a levarem para sala de aula um brinquedo. Para esse momento, era disponibilizado cerca de quarenta minutos entre a entrada na escola e o horário do lanche. 
Entende-se que o dia do brinquedo era o mais aguardado, pois permitia à criança um momento de brincadeiras surgindo com isso a possibilidade de uma interação fantasiosa entre ela e o objeto que muitas vezes não precisava ser um brinquedo. Ao manipular um objeto, em um momento de brincadeira, a criança lhe atribui novos significados. É como pegar o estojo de lápis e transformá-lo em espadas de combate ou sentar na cadeira e começar a balançar e ainda emitir sons com a boca como se estivesse no parque em um balanço (DIÁRIO DE CAMPO, 09/05/2014, p. 40). Sobre este aspecto, Pinheiro (2000, p.135) destaca que "[...]o brinquedo expressa toda uma simbologia constituída na interação criança-criança processo que envolve a construção e reconstrução de representações e valores".

No meio da tarde, em torno das 15 h00min, é servido o lanche. Nesse momento, são realizadas uma oração e uma cantiga. O ajudante do dia, a saber, um aluno de cada vez, levanta-se e junto da professora serve o lanche para quem está com a mão levantada. Normalmente, a maioria das crianças traz seus lanches de casa, mas houve casos em que aceitava o lanche da escola, pois algum coleguinha mais próximo estava comendo. É perceptível que neste momento a sala de aula se torna um ambiente propício a brincadeiras, conversas, compartilhamento de comida e experiências. Porém, a professora recomendava que elas ficassem sentadas e quietas. Mas as crianças subvertiam esse encaminhamento, visto ser a subversão uma tendência natural. A professora chamava à atenção várias vezes, porém não agia de maneira enfática e decisiva.

Posteriormente ao lanche, iniciam-se as atividades, denominadas por nós, de atividade com conteúdo pedagógico referentes ao português, matemática, história, ciências, geografia e artes. Essas atividades são realizadas, na maioria das vezes, de maneira individual e exigem das crianças bastante atenção, que não conversem ou brinquem entre si. Porém, observou-se, mais uma vez, uma reação 
diferenciada às regras instituídas. "Muitas crianças passeiam pela sala, se movimentam de várias formas em sua cadeira, conversam e compartilham materiais e saberes. Em alguns momentos, a professora chama à atenção e anota o nome do quadro e diz que vai tirar cinco minutos do parque para quem não se comportar" (DIARIO DE CAMPO, 20/03/2014). Percebe-se, portanto, que assim como certas crianças respeitavam as normas, outras resistiam a elas de alguma forma, o que demonstra que a escola não obtinha o controle desejado.

Por volta das $16 \mathrm{~h} 30 \mathrm{~min}$, acontecia o momento de recreação das crianças. Em fila, as crianças são levadas ao parque para poderem brincar. Faziam isso intensamente de maneira livre e autorizada. Esse tempo na recreação não é marcado por um planejamento. As intervenções ou sugestões das professoras são pontuais, e deixam a impressão de improviso, pois muitas vezes solicitadas pelas próprias crianças.

Há disposição para fila em vários eventos. A distribuição dos corpos em fila não se restringia à posição das carteiras na sala de aula. Qualquer deslocamento é realizado por meio de fila. Fila na saída e na entrada em sala, na recreação, para lavar as mãos ou beber água, para se posicionar no pátio em dia de apresentação artística ou hora cívica. Para a organização da fila, os lugares eram previamente determinados. Assim, a ocupação do espaço individual na fila também era definido. As crianças seguiam enfileiradas, sempre com a ala das meninas na frente da ala dos meninos. Para Foucault (2007), tais ordenamentos temporal e espacial das crianças instauram um tipo de relação que, na perspectiva da disciplina, produz um controle das ações, passando a estabelecer um conjunto de obrigações e um ritmo coletivo de respostas que as crianças devem aprender e reconhecer.

Essa forma de distribuição das crianças no espaço possibilitava uma melhor vigilância da professora sobre o grupo. Esse tipo de formação em fila, 
segundo a pesquisa de Pinheiro (2000), é considerado pela escola a melhor forma de deslocamento, pois diminui os movimentos dos pequenos. Nessa disposição estava presente a fixação de disciplinas que, cotidianamente, forjavam um corpo normatizado e bem ajustado às regras. Contudo, apesar da permanência de sua forma, a fila ganha outros ingredientes, como uma brincadeira ou caminhar de mãos dadas, por vezes uma postura corporal diferenciada do proposto, como se "arrastar pelo chão" (DIÁRIO DE CAMPO, 14/05/2014, p. 43). Neste caso, a vigilância se estendia entre as crianças, umas sobre as outras e a delação à professora era inevitável. Essa conduta revela a força e abrangência do mecanismo de coerção sobre as crianças.

Ora, percebe-se a fragilidade nesse encaminhamento ordenativo. É como se a fila, por não ter um "uso" único, "[...] acabasse abrindo brechas para que os sujeitos criem formas de comunicação, circulando outros desejos e necessidades" (DERBOTOLI, 2008, p. 56). Observa-se que as crianças vão saindo da fila e as próprias professoras não colocam nenhuma resistência. É como se não fizesse sentido permanecer naquela forma automática de se organizar.

No retorno à sala de aula, após a recreação, é realizado um exercício de volta à calma e um alongamento. Logo em seguida, inicia-se outra atividade de conteúdo pedagógico. Nesse segundo momento de atividade, percebe-se que as crianças estão bem mais agitadas. Muitas preferem brincar com seus materiais, passam de mesa em mesa, fazem a atividade em pé, em frente à sua mesa, falam mais alto que de costume.

A saída das crianças da escola inicia-se com a chegada dos pais ou responsáveis, o que ocorre por volta das $17 \mathrm{~h} 45 \mathrm{~min}$. Enquanto aguardam, as crianças brincam com massinha, realizam leituras de gibis ou brincam com brinquedos do baú. Outras ainda permanecem fazendo a atividade de conteúdo pedagógico. Diariamente, observamos que uma ou duas crianças permaneciam 
após o término do turno escolar que ocorria às $18 \mathrm{~h} 00 \mathrm{~min}$. Nesse momento, a professora deixava as crianças na portaria da escola sob os cuidados do vigilante ou de algum membro do corpo diretivo. Durante esse tempo de espera, verificouse que as brincadeiras realizadas possuíam pouca movimentação corporal e eram individualizadas, às vezes nem mesmo havia brincadeiras.

Segundo Derbotoli (2008), os tempos institucionais caracterizam-se por rotinas de organização de espaços e relações. Influenciam ritmos e disposições às ações das crianças. Momentos de aprender, de alimentar, de vivenciar aspectos culturais, de interagir e socializar, além de brincar e movimentar-se aparecem como tempos fixos e estruturantes de um ritmo constante e invariante da cultura escolar. O que parece variar um pouco são as estratégias utilizadas para preencher os intervalos de tempo nos espaços.

Essa organização dos tempos e dos espaços acontece no decorrer das ações cotidianas e, pela sua repetição, tornam-se rotinas. É relevante ressaltar que, dependendo das ações das crianças e da professora, ou até mesmo de outros agentes (outras professoras, direção, orientadora educacional), a rotina muitas vezes se tornou mais flexível, os tempos eram ampliados ou reduzidos, como também era modificada a ordem de ocupação dos espaços. Com isso, percebe-se claramente, que o tempo e o espaço não se resumem à sua cronologia e metragem. Apresentam-se como limites que permitem emergir as múltiplas dimensões humanas, as diversas formas de expressão, o imprevisto e os saberes espontâneos infantis.

\subsubsection{Portão de entrada}

Em uma pequena extensão da entrada, sob uma árvore que oferece sombra, as crianças aguardam a abertura do portão acompanhadas de seus responsáveis. Observou-se que, geralmente as meninas, neste espaço, realizavam 
as brincadeiras cantadas com as mãos, enquanto outras tiravam fotos de si mesmas $\left(\right.$ selfies $^{5}$ ) e com outros coleguinhas. As fotos eram tiradas com celulares, em geral, dos responsáveis. Os meninos brincavam de jogo do bafo e conversavam bastante. Porém, observa-se que a maioria das crianças permaneciam próximas aos seus responsáveis sem realizar nenhum tipo de movimentação.

É importante ressaltar a influência da cultura midiática sobre a cultura infantil. Belloni (2004) destaca que as crianças são sujeitos do processo de socialização da ação de várias instituições, entre as quais a mídia e, em especial, a televisão. De acordo com Passos (2013), a mídia tem estabelecido formas diferenciadas de observar e de interpretar as situações rotineiras da vida, transformando alguns conceitos, inclusive a concepção de infância e o modo de brincar. Brincadeiras com aparelhos eletrônicos, bonecos de histórias de filmes e desenhos permeiam o universo infantil abundantemente. Esse aspecto ocorre porque a mídia passou a ser veiculada como produtora de valores presente de forma concreta na sociedade atual.

Ao tocar o sino, era realizada a abertura do portão. A movimentação é intensa e controlada por alguns funcionários da escola: "Crianças, devagar, não corram... direto para a sala...” (DIÁRIO DE CAMPO, 29/05/2014). Ainda no corredor de acesso às salas de aulas as crianças exploram esse percurso subvertendo o apelo dos funcionários. Elas se juntam e conversam, riem e ainda apostam corridas até a sala de aula. A pintura colorida na parede, bem como o mural montado com temas comemorativos, que são modificados de tempos em tempos, as frases incentivadoras parecem despercebidas pelos olhos das crianças. Esse momento da entrada se destaca pela cumplicidade do encontro diário com a

\footnotetext{
${ }^{5}$ Fotografia que alguém tira de si mesmo, em geral com smartphone ou webcam, e carrega em uma rede social. Disponível em http://www.oed.com. Acesso em 22 de abril de 2015.
} 
melhor amiga, com o primo de brincadeira e travessuras, mas também percebese, entre as crianças menores, um momento de dolorosa separação do colo seguro dos pais. Notou-se, em alguns dias, crianças chorando para não ficarem na escola, querendo permanecer com seus pais.

O choro não significa que a criança não está gostando da escola, apenas que a despedida dos país lhe é algo dificil. Como afirma Balaban (1988, p. 25) "[...] a separação é uma experiência que ocorre em todas as fases da vida humana”. Destaca que a separação afeta às crianças e os pais. Faz brotar sentimentos nos professores. O início da vida escolar pode ser uma ocasião excitante ou também uma ocasião agradável. Junto com aqueles que realmente estão encantados por estarem iniciando sua vida escolar, existem frequentementoutras crianças chorando ou pais tensos e nervosos.

Sobre esse aspecto, Amorim, Vitoria e Rossetti-Ferreira (2000) relatam pesquisas que se debruçam sobre o momento de entrada da criança pequena na creche e o exame destas nas inter-relações entre a criança, a família e professoras. Sugerem que a iniciação escolar deve priorizar o bem-estar da criança pequena como elemento essencial ao seu desenvolvimento integral e valorizam a construção de um ambiente acolhedor como um elo de confiança que se estabelece entre o bebê, a família e os adultos da instituição.

Em relação a essa particularidade, Sacristán (2005, p.102) destaca que, estar um tempo nas escolas é um rito de passagem naturalizado na vida dos indivíduos, cujos fins são aparentemente óbvios ocupando um lugar central na experiência das pessoas, tendo se transformado em um marco de referência que introjetamos e que projetamos quando o percebemos e valorizamos.

\subsubsection{Sala de aula}

As salas de aulas do prédio central estão dispostas uma ao lado da outra. As paredes da sala são coloridas com murais, armários, livros, cadeiras e mesas 
para a professora e crianças. Em toda decoração, encontravam-se letras coloridas, calendário, números e datas de aniversários, silabários e artefatos para mediar o aprendizado. A disposição do mobiliário segue uma organização tradicional das mesas e cadeiras, enfileiradas em duplas voltadas para a frente, deixando um espaço reservado para circulação da professora. Percebe-se que as "coisas" estão dispostas na sala de forma a criar uma dinâmica de obediência dos alunos para a professora. Segundo Buss-Simão (2012), essa espacialização sistematiza minuciosamente os movimentos e os gestos. Indica, especialmente, uma opção pela manutenção da mesma estrutura, assim como aponta França (1994 apud BUSS-SIMÃO, 2012, p.26).

A opção pela manutenção da mesma estrutura é, também, a opção pelas relações existentes, as quais oferecem o conforto de uma situação prementemente sob controle, ainda que isso seja, em grande parte, uma forma de ilusão, pois a imprevisibilidade e o descontrole coabitam com o esperado.

Há na sala dois cestos com vários brinquedos (carrinhos, bonecos, corda, relógio, telefone, animais, monstros, fantoches, legos, entre outros). Às crianças é permitido brincar na entrada, enquanto a professora não começa a aula e na saída, depois de realizadas todas as atividades. Porém, não são permitidas as brincadeiras no espaço em frente às mesas e cadeiras, próximo ao quadro branco. É solicitado a elas que peguem um brinquedo e fiquem sentadas para brincar, isto é, no seu espaço individual. As crianças, entretanto, escolhem seus brinquedos e iniciam suas brincadeiras nesse lugar proibido, percorrem todo o espaço da sala, e alguns, ainda, tentam sair da sala. Nesse evento é possível identificar uma variedade de pequenas ações e movimentos que sugere a não submissão dos corpos à imobilidade.

Em sala são realizadas as atividades aqui denominadas de atividades de ensino de conteúdo. Também em sala é promovida a institucionalização da alimentação, da higiene, da oração, dos conhecimentos e das aprendizagens, 
daquilo que é "servido" e deve ser ensinado e aprendido. Durante o lanche e ensino de conteúdo, notou-se a exigência de manutenção do silêncio e da ordem. Sempre foi exigido às crianças comportamento "imóvel": não levantar, sempre pedir a autorização da professora para beber água ou ir ao banheiro, não conversar e responder às perguntas a elas direcionadas. Contudo, o que podemos observar é que, em sua grande maioria, as crianças realizavam todas as atividades solicitadas, mas não em total silêncio e nem imóveis diante dos acontecimentos.

E é justamente na sala de aula que as crianças permanecem a maior parte do tempo, aproximadamente cinco horas por dia. Por esta razão, entende-se que, apesar da disposição dos mobiliários, das paredes, da porta sempre aberta, da ampla janela transparente, das regras impostas, enfim, mesmo com a constante vigilância, as crianças fazem uso da sala de aula o espaço do movimentar-se. O corpo não fica sentado na carteira, pois vai ao banheiro, levanta-se, espreguiçase, faz "contorcionismo", aponta lápis, pega um brinquedo, entre outras ações consideradas impróprias. Esse espaço de resistência e transgressão está além do visível. As crianças transgridem a autoridade da professora em rápidos lances de folga.

[...] enquanto as crianças cumpriam a tarefa de desenhar sobre a história do filme a professora saiu da sala. Neste momento, a maioria das crianças, quando perceberam sua ausência, levantaram-se do lugar e foram para a porta esperá-la. Quando um disse "lá vem a tia!", todos correram de volta e sentaram-se no lugar, com a cabeça na tarefa. De repente, Camilla grita: "A tia, a tia! Vamos sentar, se não a gente fica sem parque (DIÁRIO DE CAMPO, 26/03/2014, p. 15).

Do trecho retirado do diário de observação do campo logo acima, impõese refletir acerca da escola como construção social e compreendê-la no seu fazer cotidiano, em que os sujeitos não são apenas agentes passivos diante da estrutura, trata-se de uma relação em contínua construção de conflitos e negociações em função de circunstâncias determinadas (Dayrell, 1996, p.136). O 
que implica escrever que o espaço escolar é um espaço sociocultural, cheio de transgressões e de acordos, alianças e estratégias individuais e de grupo. Segundo Dayrell (1996), sujeitos socioculturais são também seres concretos e plurais.

\begin{abstract}
São pessoas vivas e reais, existindo a partir de sua corporeidade e lugar social, a partir de sua condição de mulheres, homens, negros, brancos. Pertencem a diferentes raças e etnias. São crianças, jovens ou de mais idade; adeptos de variadas crenças e costumes. Têm desejos, projetos e atribuem variadas significações às suas experiências e ao mundo. Para entendênde-los, é necessário considerar esses seus atributos, sejam eles adscritos ou adquiridos, pois tudo isso matiza sua existência e condição (DAYRELL, 1996, p.185).
\end{abstract}

Sob o ponto de vista de um olhar atento, a sala de aula representa um recorte significativo, pois congrega as experiências de vida de muitos sujeitos, cada qual com sua cultura, sua crença, seu valor, sua sensibilidade. A riqueza dessa multiplicidade de conhecimentos deve ser objeto de atenção do educador, pois o processo de interação professor-aluno resulta em um aprendizado mútuo, pois o mediador que ensina, também aprende.

Relevante também assinalar que, mesmo com a constante rigidez e autoridade, muitas vezes, a professora se mostra convalente a algumas atitudes das crianças.

Próximo ao horário da recreação começou a chover e por isto não tiveram o momento da recreação. Nesse horário a professora continuou a passar atividade de conteúdo, mas percebi que as crianças não estavam mais tão atentas ou concentradas para a atividade. Elas estavam bem agitadas. A professora falava e muitas crianças conversam e brincavam no momento em que ela explicava a atividade. O Romeu brincava com sua mochila de lanche (que tem formato de carrinho). Quase todas as crianças conversavam muito umas com as outras. O Bart girava sua tesoura na mesa fazendo um grande barulho. A todo momento a professora chamava a atenção de todos, mas ela não tinha mais como barganhar o silêncio e a atenção em troca do parque. A brincadeira com a tesoura se espalhou. Agora havia 3 ou 4 crianças girando a tesoura na mesa e fazendo barulho. Novamente, a professora interrompe para chamar à atenção. Porém, um pouco depois dessa fala, 
ela senta-se e começa a preencher o diário de classe. Pede para as crianças que não terminaram a tarefa dirigir-se individualmente a sua mesa e de maneira velada permite que as crianças continuem suas brincadeiras (DIÁRIO DE CAMPO, 14/04/2014, p. 28).

Claramente, tem-se a quebra da rotina imposta pela escola, na sala de aula, pela mão da professora. As regras, que estão expressas na autoridade da professora e configuram a criança no espaço da sala, são redefinidas quando uma ou algumas crianças transgridem a ordem imposta. No entanto, isso é transformado e ressignificado no espaço da sala de aula. Podemos perceber que as crianças também apropriam-se dos espaços de modo a res-significá-los, a transformá-los, conferindo-lhes outros sentidos e formas próprias de sociabilidade.

A atitude de algumas crianças diante da situação adversa imposta pelo tempo metereológico e o posicionamento da professora nos informa que houve uma transgressão do espaço. As crianças desapropriaram e criaram novos sentidos para a produção da professora. Elas desconstruíram o espaço construído pela professora. A própria professora transgrediu a rotina do tempo e espaço escolar quando redimensionou sua interveção diante das crianças. Em se tratando de espaço, a escola não é apenas uma célula física, ela é também uma célula orgânica, com movimentos e dinâmicas contra as quais o próprio corpo tende a se rebelar e se reveler. Sobre esse aspecto, Buss-Simão (2012) acentua que as crianças criam ajustamentos, a fim de satisfazer necessidades e interesses. Elas tornam evidente a centralidade da dimensão corporal. "O corpo não precisa somente sentar, ele precisa deitar, dobrar, esticar, encolher, conter, relaxar, subir, descer. Enfim, o corpo está na base de toda experiência social das crianças e na construção de suas relações" (BUSS-SIMÃO, 2012, p. 270). 


\subsubsection{Pátio e corredores}

$\mathrm{Na}$ escola há dois estreitos corredores de circulação interna que conduzem as crianças por meio de uma movimentação corporal restrita. Os corredores são lugares onde as crianças não devem permanecer, mas são passagens obrigatórias. Conduzem para o parque e quadra de esportes, para os banheiros do prédio anexo, para as salas administrativas da escola, bem como para entrada e saída de alunos, professores e funcionários. De uma forma ou de outra, a turma de crianças deve percorrê-lo em fila e sem correr. O trajeto deveria ser realizado em silêncio e de maneira muito rápida. Sobre esse aspecto, Gonçalves (1996) denuncia a precária situação da estrutura física da escola pública do Brasil, como resultado de um modelo de desenvolvimento econômico, social e político que se expandiu e se enraizou.

Em nome da economia, as soluções arquitetônicas são comprometidas: passagens e corredores estreitaram-se favorecendo as filas e a disciplina, aberturas pequenas, pouca luz e cor, materiais de baixa qualidade e ambientes cada vez menores (GONÇALVES, 1996, p. 216).

Para Faria Filho e Vidal (2000), a construção de espaços adequados para o ensino, bem como a definição de tempos de aprendizagem, estavam relacionadas não apenas à possibilidade de a escola vir a cumprir as funções sociais que the foram crescentemente delegadas mas, também, à produção da singularidade da instituição escolar e da cultura que lhe é própria. Neste sentido, apontam os tempos e espaços como parte da ordem social e escolar, orientando de maneira sutil o empobrecimento da dinâmica corporal.

Esses corredores desembocam em um pátio. O pátio é um espaço coberto com um palco construído em cimento e piso cerâmico. Possui duas caixas de som fixas nas pilastras, que estão levantadas no meio do espaço, reduzindo o tamanho de seu aproveitamento. A utilização desse espaço é destinada a apresentações artísticas e culturais, hora cívica, reuniões coletivas com os pais e 
festas comemorativas, além de outras atividades pedagógicas envolvendo toda a escola.

Na prática cotidiana, o pátio era utilizado para as apresentações artísticas e culturais que ocorriam, geralmente, as quintas-feiras. Para esse momento, também observamos um padrão de acontecimentos a serem contemplados. Iniciavam com cada professora encaminhando sua turma, com as crianças em fila e as posicionavam sentadas no chão, uma turma do lado da outra. Após o ordenamento de todas as turmas, a coordenadora de turno ou a diretora detinha a palavra. A todos solicitava silêncio e convocava para fazer oração. Na maioria das vezes se pronunciava pedidos e as crianças os repetiam, terminando com a uma música infantil gospel ${ }^{6}$. Logo após a oração, a programação iniciava com a hora cívica. De acordo com os discursos observados, a hora cívica é um momento de reflexão e vivência de atitudes que resgatam valores como o civismo, patriotismos, convivência saudável, respeito, tolerância, cooperação, participação e responsabilidade (DIÁRIO DE CAMPO, 29/05/2014, p. 56).

Nesses dois momentos iniciais, percebemos forte disposição ao controle corporal das crianças objetivando manter a ordem para que a atividade seja realizada. Para a oração, os corpos das crianças devem se posicionar de pezinhos juntos, mãos entrelaçadas e cabecinha baixa e todas devem agradecer repetindo as palavras da professora. $\mathrm{Na}$ hora cívica é solicitada às crianças se posicionarem de pé, um atrás do outro, mãozinha no peito, em silêncio e especialmente, ficar “igual a um soldadinho, imóvel no lugar” (DIÁRIO DE CAMPO, 10/04/2014, p. 25), para, de acordo com a professora que coordena a hora cívica, demonstrar respeito à pátria.

\footnotetext{
${ }^{6}$ Gospel pode ser entendido como um estilo de música dos cultos religiosos, que possui sua origem na comunidade negra norte-americana. Disponível em http://www.significados.com.br/gospel. Acesso em 22 de abril de 2015.
} 
Percebemos, a princípio, que as crianças aderem a essa organização. Ao chegar no pátio observamos que elas já entendem a organização e se posicionam na fila como de costume. No entanto, no decorrer do tempo identificamos que as crianças apresentam outros arranjos corporais. Saem da fila formada, cutucam uns aos outros, brincam de "guerrinha" com os pés e rodopiam no chão. Conversam bastante, sempre aproveitando o momento em que as professoras não estão vendo. Ou seja, as crianças "dão um jeitinho" de não se fazerem presentes aos olhares de disciplina e mecanização de seus corpos. Mais uma vez é possível verificar que os tempos e espaços escolares são organizados pelos adultos, de modo a priorizar o condicionamento e a disciplina das crianças.

Para outras atividades, como jogos e brincadeiras, observou-se que o espaço do pátio pouco é utilizado. Aconteceu apenas duas vezes em todo período da pesquisa. Em um desses dias ocorreu devido a impossibilidade, por causa da chuva, das crianças terem o momento da recreação no parque. Nesse dia, eles utilizaram o pátio para uma brincadeira coordenada pela professora durante os quinze minutos finais do turno. Mesmo sendo pouco utilizado, com o objetivo de recreação ou jogos e brincadeiras pedagógicos, o pátio foi lembrado e identificado, nos desenhos e conversa com as crianças, como um espaço que elas poderiam brincar. Destacaram que quando "não tem parquinho e a tia deixa, elas brincam no pátio de "estátua", "corre cutia" e "brincar de carrinho" (LUCAS, LUIS e JUNIOR, DIÁRIO DE CAMPO, 30/04/2104, p.36).

\footnotetext{
${ }^{7}$ É uma brincadeira tradicional onde um dos participantes, escolhido para ser o líder, coloca uma música. Enquanto a música toca, os jogadores dançam livremente, mas quando o líder disser: "Estátua!", a música pára e todos os participantes devem congelar-se e manter-se em mesma posição sem se mexer. A última estátua a permanecer de pé será a vencedora. Disponível em: www.brasilescola.com. Acesso em 05 de janeiro de 2015.

${ }^{8}$ É uma brincadeira tradicional e regional do Centro-oeste brasileiro. Todos devem sentar no chão, formando um círculo. Uma das crianças corre do lado de fora da roda com um lenço ou bola na mão, ao ritmo da ciranda. Ao fim da cantoria, a meninada que está sentada abaixa a cabeça e tapa os olhos com as mãos. Quem está correndo deixa cair o lenço ou bola atrás de um dos sentados. Este deve pegar o lenço e correr atrás de quem o deixou. $\mathrm{O}$ lugar vazio da roda é o pique. Quem perde, fica fora da roda e a brincadeira recomeça. Quem é pego tem de pagar
} 
O brincar de carrinho, neste espaço, é representado no desenho de Júnior (7 anos) - (figura 3). Seu traçado apresenta o espaço do pátio tal como ele é: um local delimitado por paredes e um palco, além de uma cerca gradeada que separa esse lugar do espaço externo. Em detalhe, Júnior ainda rabisca uma arquitetura de cimento que pode ser utilizada para sentar e assistir às apresentações artísticas.

Em vista desse apontamento, acentua-se a que as práticas corporais, como as brincadeiras populares, fazem parte do repertório infantil e o pátio é entendido pelas crianças como um espaço favorável ao despertar das brincadeiras lúdicas. Fernandes (2004) retrata a existência de uma cultura infantil, que é formada por elementos culturais que são caracterizados por sua natureza lúdica, cujos elementos são folclóricos. A cultura popular é uma cultura do povo e alcança todos os grupos sociais, inclusive as crianças. Através das brincadeiras populares a criança se insere na memória coletiva, "[...] dando sentido ao seu mundo e sua existência" (CARVALHO, 1998, p. 45).

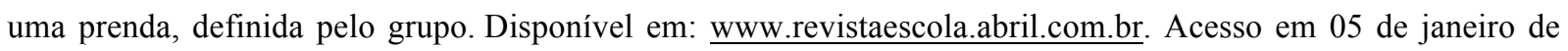
2015. 


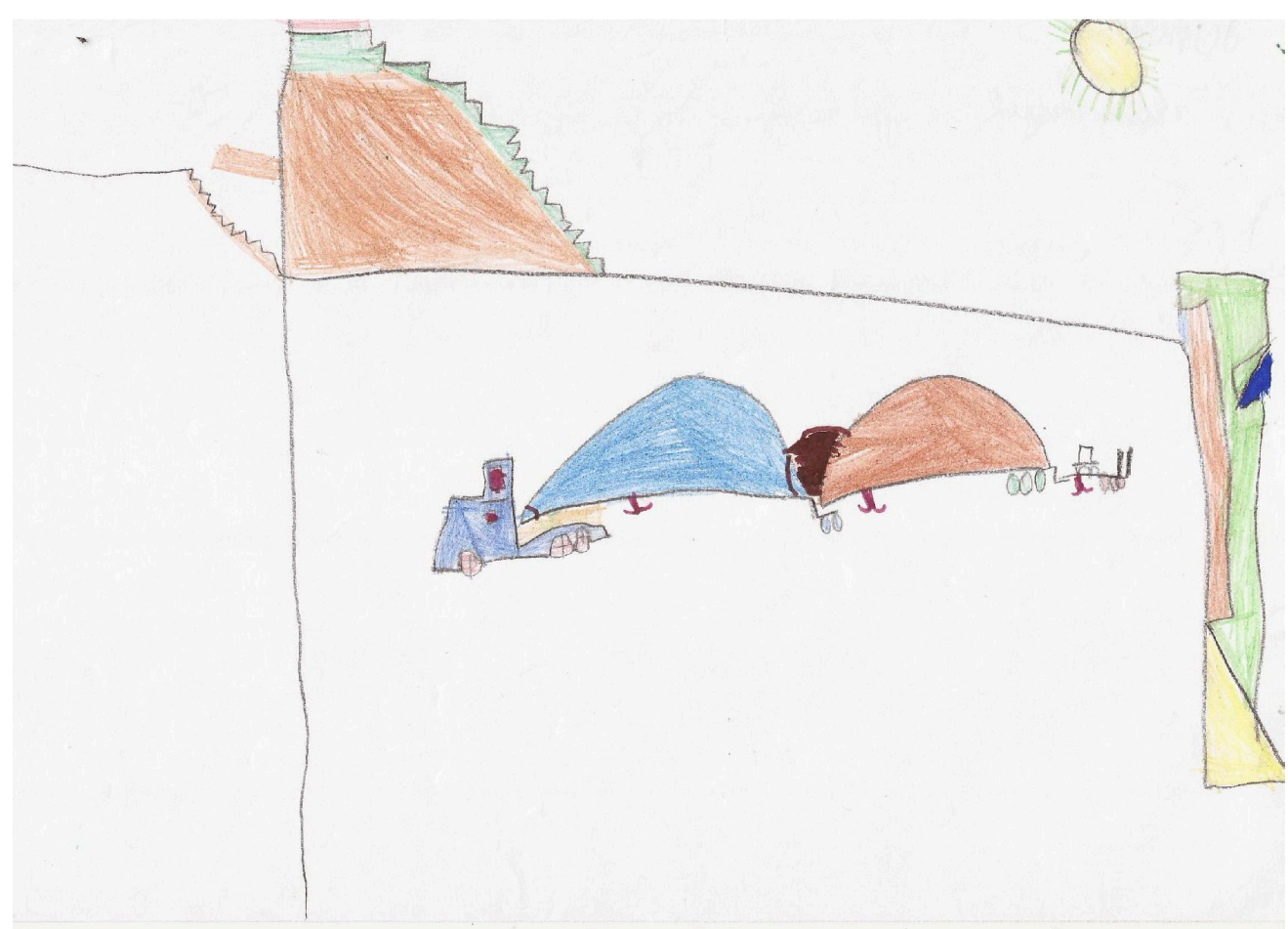

Figura 3: Minha brincadeira preferida: caminhão no pátio - Júnior (7 anos). Fonte: Da autora.

\subsubsection{Parque e quadra de esportes}

O parque e a quadra de esportes são os espaços destinados à recreação das crianças. Localizam-se nos fundos da escola, próximo ao estacionamento dos carros dos funcionários e ao prédio anexo ao central. Observa-se uma vasta área verde com banquinhos em cimento e um espaço molhado que abrigava duas duchas de água, que naquele período estavam inutilizadas. O parque possui uma área entrecortada pelos brinquedos dispostos um ao lado do outro. Todos são de ferro e ficam sobre caixas de areia.

Os brinquedos são dois escorregadores, um com a escada em forma de foguete e uma ponte de madeira entre a escada e o escorregador, dois balanços, dois trepa-trepas, um aparelho com duas argolas e uma gangorra. Todos estão em boas condições de uso. Além disso, há uma casinha de bonecas, que as crianças, em geral, usam para brincar de esconder. 
A quadra de esportes é pequena, com duas traves de gol e cercada por um aramado. É cimentada e possui demarcações de uma quadra de futsal pintadas em amarelo. Também está em boas condições de uso, pois foi construída havia três anos. De forma geral, são os meninos quem mais utilizam a quadra por jogarem futebol. Mas observamos a participação das meninas em alguns momentos.

De acordo com a rotina escolar, as crianças frequentavam o parque e a quadra diariamente, permanecendo nele durante trinta minutos. Entretanto, salientamos que nem sempre essa rotina é cumprida. Alguns aspectos são levados em consideração, pela professora, para que a rotina da recreação seja autorizada, entre eles, a situação do tempo (ensolarado ou chuvoso), o comportamento das crianças (se fazem ou não bagunça), o término das atividades de conteúdo (quem não terminar fica em sala) e, por último, o próprio andamento da rotina (se há tempo ou não de recreação).

Os tempos e espaços da recreação foram utilizados de diversas maneiras, mas sempre mediados por brincadeiras livres. A professora relatou que durante a recreação no parque deixa as crianças brincarem livremente, preocupando-se apenas em monitorá-las para que não se machuquem ou briguem umas com as outras. Nesse momento, a professora assume outros papéis, ficando mais como observadora, intervindo somente quando solicitada ou para intermediar algum conflito, disputa e/ou agressões. As interações nas quais o adulto está mais presente apresentam-se com menor frequência na espacialidade do parque, o que nos remete a um tempo de estar fora da sala, “[...] e, por conseguinte, com maior constância na espacialidade da sala de referência - que nos remete a um tempo inverso, o tempo de ficar dentro da sala" (FRANCISCO, 2005, p. 128).

Pode-se entender essa postura adotada pela professora de duas maneiras: os momentos em que as crianças brincam no espaço do parque, criado pelos 
adultos, é tido como o momento para as brincadeiras livres e, por serem livres, entende-se que não necessitam de planejamento ou organização diária. Ou, ainda, que as brincadeiras são consideradas livres porque são as crianças que escolhem do que querem brincar, onde querem brincar, com o que vão brincar e por quanto tempo vão permanecer em uma brincadeira e noutra ou em várias simultaneamente. Isto é, exercem autonomia de seus tempos e espaços e de seus corpos, o que na sala de aula, percebe-se ser enfraquecida.

Diante desses dois aspectos, é possível inferir que o momento da recreação é considerado pela professora e pela escola como tempo e espaço das crianças. Porém, nota-se que é um tempo controlado e vigiado. Essa postura não passa despercebida aos olhos infantis. As crianças da turma entendiam naquele momento que, apesar da professora não "ditar" o que deveriam fazer, também não significava que poderiam fazer o que quisessem. Destaca-se o desenho (figura 4) e relato de Vytória (6 anos):

Pesquisadora: - qual a sua brincadeira preferida?

Vytória: - parquinho.

Pesquisadora: - foi o que desenhou aqui? (Refiro-me ao desenho que ela acabara de me entregar).

Vytória: - aí são dois escorregadores, meu balão subindo e as professoras sentadas, olhando brincar.

Pesquisadora: - e por que desenhou as tias em sua brincadeira?

Vytória: - elas ficam olhando a gente para não dá briga e não podemos sair para o estacionamento, nem escorregar junto. A gente pode correr e brincar na casinha, mas sem brigar. A tia fica olhando a gente com as outras tias e chama pra perto dela se for 'pro' estacionamento (DIÁRIO DE CAMPO, 30/04/2014, p.35).

Vytória (6 anos) desenhou seu espaço do brincar de maneira bem alegre e amorosa. Observa-se uma representação bem colorida, com muitos corações e elementos da natureza sorridentes. Esse desenho passaria despercebido se não fosse a fala dessa criança, pois bem em um cantinho do escorregador encontra-se projetado em seu grafismo um banco com duas cabeças: são as "tias" 
monitorando o brincar de todos. "O adulto não abre mão de ver tudo e todos, ocupando os espaços mesmo onde seu corpo não vai, ocupando-o com seu olhar, com a projeção de sua presença" (FRANCISCO, 2005, p. 126).

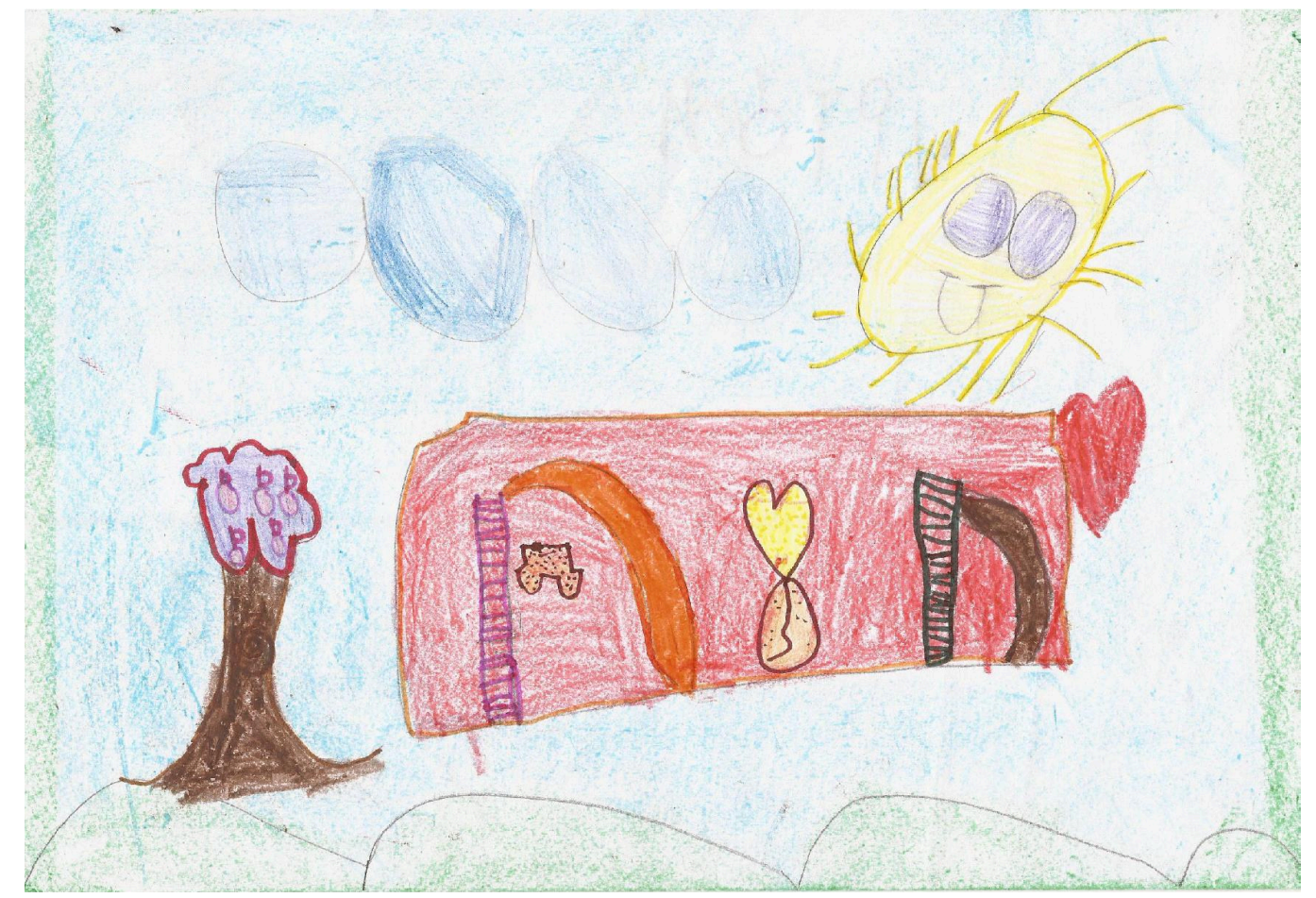

Figura 4: Minha brincadeira preferida: parquinho - Vytória (6 anos).

Fonte: Da autora.

A própria organização do espaço, pela disposição de seus brinquedos, dentro de um cercado com areia, fincados no chão, está sutilmente carregada de regras, na medida em que explicitam pelo brinquedo o que se pode ou não fazer. A perspectiva das brincadeiras realizadas durante o tempo da recreação era mais coletiva. As crianças se uniam em grupos para brincar de diferentes formas, tanto nos aparelhos quanto na areia, na quadra, nos bancos e casinha de bonecas, ou simplesmente correndo pela área. Somente no espaço destinado às duchas frias é que não eram autorizadas brincadeiras, bem como a saída ou permanência para o estacionamento, longe dos olhares adultos. Havia um movimento incessante de interação indivíduo-grupo, entre duplas de crianças ou grupos maiores, inclusive 
com crianças de outras turmas, já que esse tempo é compartilhado entre duas ou mais turmas.

Dessa forma, conforme Ferreira (2002), na ordem institucional se entrelaçam dois contratos sociais: o dos adultos com as crianças (brincar sem inventar moda) e o das crianças entre si (brincar com outras crianças). Esse contrato social, seja ele consciente, verbalizado ou não, carrega consigo um conjunto de direitos e deveres que visam harmonizar as relações que ocorrem nesse espaço. Porém, novamente, assim como no espaço da sala de aula, identifica-se que as crianças inventam moda e acabam transgredindo o estabelecido "[...] - em que o tempo de fuga, de contra-ordem, transforma-se em tempo de busca, busca do novo, da emoção, da descoberta, do prazer ... busca de si e do outro (FRANCISCO, 2005, p. 129).

Uma das regras mais explicitadas pela professora é a partilha dos materiais, tais como bola, corda, elástico, brinquedos do parque, a casinha de bonecas e até mesmo o gramado. As crianças devem "sempre partilhar tudo; a amizade, as crianças não devem entrar em conflito; e o cuidado, as crianças devem cuidar dos materiais/objetos/brinquedos e cuidar de seu próprio corpo e do corpo de seus pares" (FRANCISCO, 2005, p. 130). Devem evitar brincadeiras e situações que as exponham ao perigo e ao conflito.

De acordo com Francisco (2005), com base nos preceitos de Corsaro (2002), as brincadeiras das crianças são conflituosas por desencadearem muitas disputas, e que o adulto tende a interpretar essa relação como algo negativo, por causa do conflito gerado pela disputa. Para o autor, é importante o adulto estar atento, pois essa disputa pode estar ligada ao fato de os recursos serem escassos. $\mathrm{O}$ parque não tem um brinquedo para cada criança, fato que explicita a regra institucional do princípio da partilha, pois tudo o que existe é de todos, todos têm que aprender a partilhar. São princípios pedagógicos, princípios políticos e de 
cidadania que trazem consigo uma grande contradição, porque geram a disputa.

Registramos que o momento da recreação no parque e na quadra de esportes foram os tempos e os espaços mais citados pelos sujeitos da pesquisa como preferidos para brincadeiras, tendo, dessa forma, forte representação para os mesmos. Evidencia-se tais preferências no percentual de desenhos produzidos, bem como nos registros de conversas. Em um total de 26 desenhos realizados a partir da pergunta-tema "minha brincadeira preferida", 84,6\% esboçaram um desses dois espaços, isto é, 22 produções.

O espaço físico do parque, com seus brinquedos, apareceu em 9 produções. A análise dos desenhos e das falas das crianças confirmam suas preferências.

Eu me desenhei brincando no trepa-trepa e depois no escorregador do parque. A hora do parque é o momento que mais gosto na escola (Graziela - 6 anos. DIÁRIO DE CAMPO, 30/04/2014, p.35). 


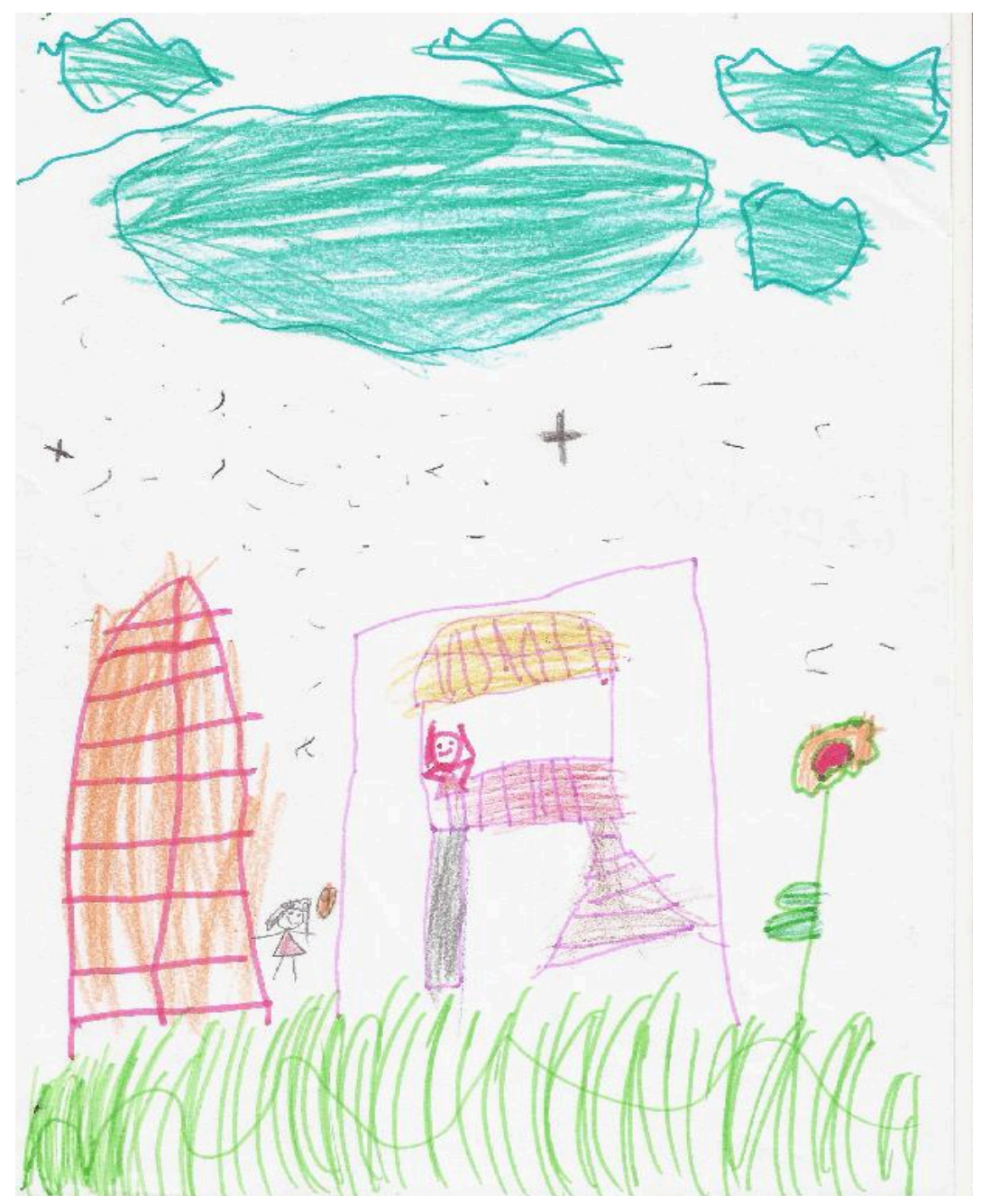

Figura 5: Minha brincadeira preferida: trepa-trepa e escorregador - Graziela (6 anos). Fonte: Da autora.

O desenho de Graziela (figura 5) esboça claramente dois brinquedos que formam o conjunto do parque. Ela se desenha em brinquedos distintos (trepatrepa e escorregador), mas em um único momento, a saber, o da recreção, que as crianças denominavam também de hora do parque, e que ocorria, observando o horário relógio, geralmente as $16 \mathrm{~h} 30 \mathrm{~min}$. O desenho é bem colorido e apresenta, além de elementos da natureza (nuvens e flor) uma expressão facial sorridente, o que pode significar um sentimento de felicidade em participar desse tempo e espaço de brincadeiras. 
As crianças demonstravam muita satisfação em realizar atividades no parque. Agiam com desenvoltura e certeza do que queriam: brincar intensamente, movimentar seus corpos sem broncas ou castigos. De acordo com Pinheiro (2000), um dos possíveis motivos dessa preferência é a possibilidade de liberdade e criatividade oferecida pelos brinquedos e espaço físico do parque, além da ausência de regras muito rigorosas.

Em um dos desenhos confeccionados, Felipe destaca sua preferência, a qual fora confirmada e em nossa conversa: "desenhei pulando corda. Também gosto de jogar bola. Gosto mais de pular corda" (Felipe - 6 anos. DIÁRIO DE CAMPO, 30/04/2014, p.36).

Felipe refere-se a sua brincadeira preferida (Figura 6), que é pular corda. Retrata-se em seu desenho segurando uma ponta da corda e mais duas amigas participando da brincadeira. Evidencia-se no desenho sorrisos em seus rostos e elementos da natureza, tais como, um sol sorridente e nuvens azuis, indicando alegria e satisfação por aquele momento. $\mathrm{O}$ desenho demonstra a presença da cultura lúdica popular no cotidiano infantil. As brincadeiras tradicionais estão presentes na escola e se apresentam de forma significativa durante os momentos livres das crianças. Identificou-se sua presença nos desenhos das crianças.

Fernandes (2004), em seu estudo sobre as 'trocinhas' do Bom Retiro, destaca que a cultura infantil é enriquecida com vários aspectos da cultura popular folclórica. Porém, [...] "abrange alguns elementos complexos de natureza não folclórica, como o futebol ou a natação" [...] (FERNANDES, 2004, p. 245). [...] "Continuamente, vê-se o pesquisador diante de fatos folclóricos ainda não registrados". Portanto, enfatizamos que na cultura infantil há aspectos internalizados pelas crianças que se apoiam em elementos da cultura adulta. Muitas vezes, congregando os valores sociais e tradicionais, observados nas brincadeiras experienciadas pela turma pesquisada, como "papai e mamãe" e 
"polícia e ladrão". Contudo, verifica-se a predominância das invenções e reinvenções por parte das crianças, concedendo às suas brincadeiras e brinquedos modificações e estruturas exclusivas do universo infantil.

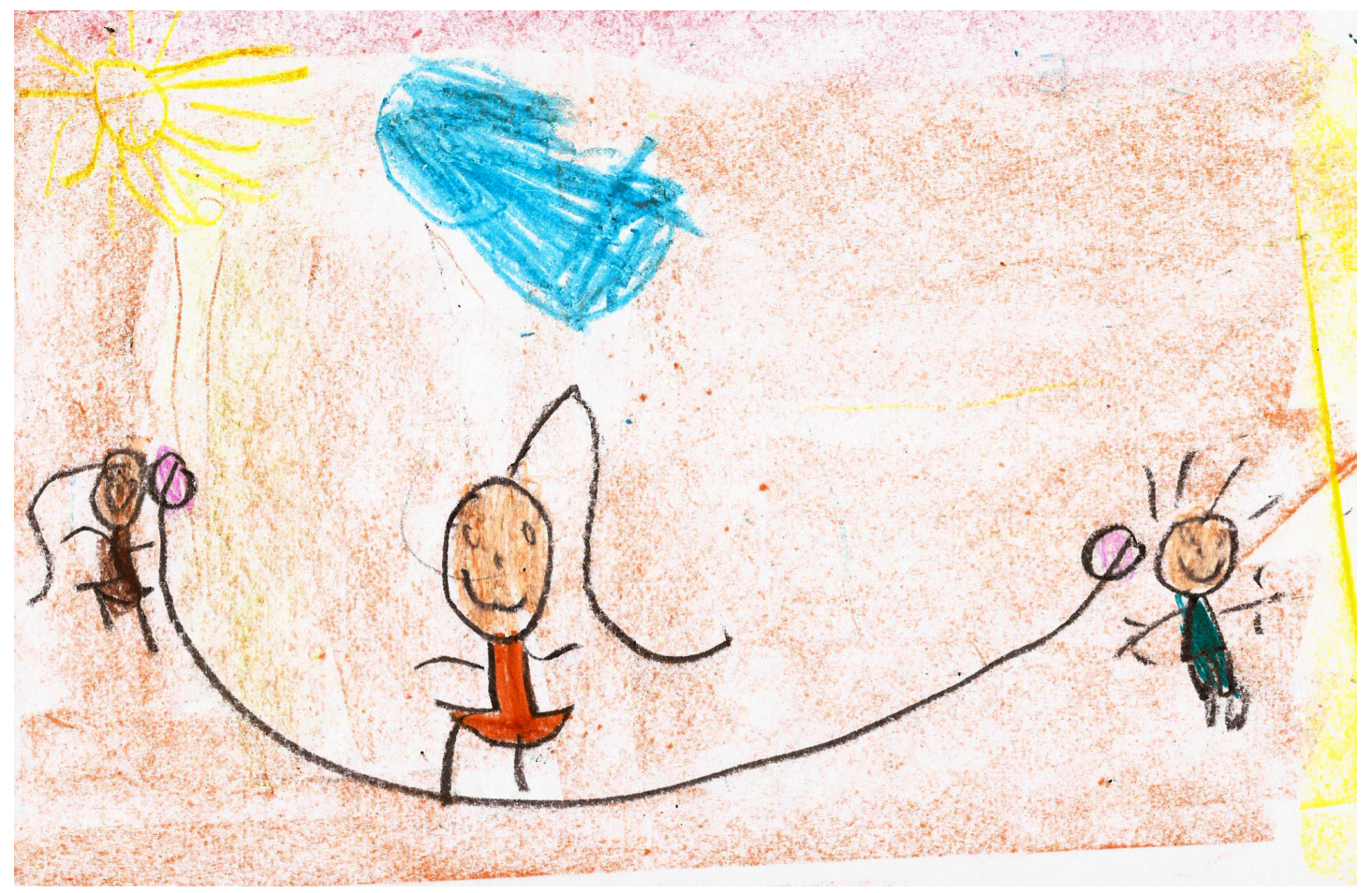

Figura 6: Minha brincadeira preferida: pular corda - Felipe (6 anos). Fonte: Da autora.

Em outras produções, identificamos outras brincadeiras típicas do acervo infantil, como o "pique alto" e "pega-pega", representado por Nelson (7 anos) (figura 7). No seu desenho, Nelson divide a folha em duas partes e demonstra suas brincadeiras preferidas. Na primeira metade da folha estampa o pega-pega. São três crianças brincando em um espaço delimitado, mas que parecem correr umas entre as outras no intuito de "driblar" o pegador. Na outra metade, ilustra várias crianças no alto dos brinquedos ao ar livre. 


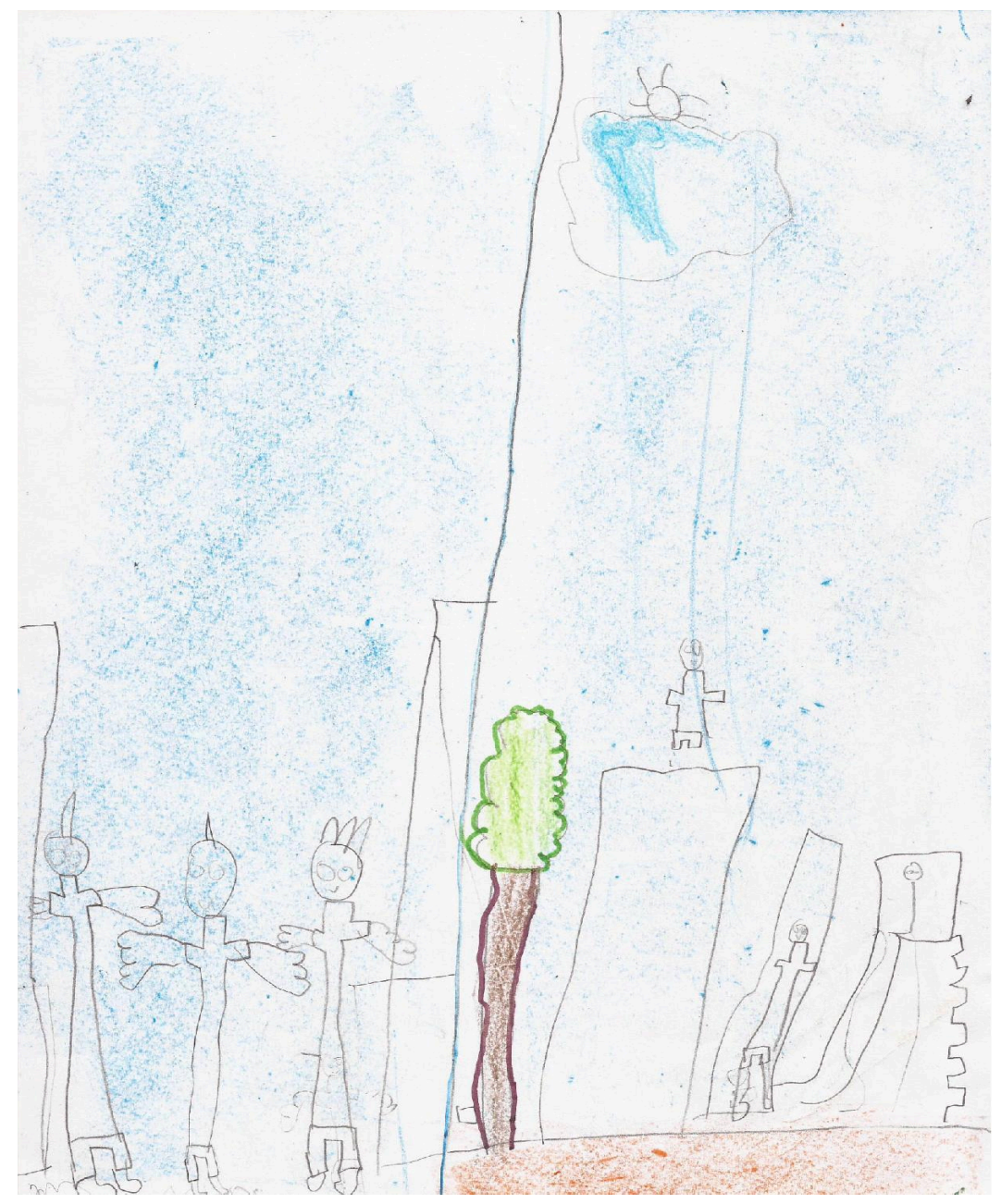

Figura 7: Minha brincadeira preferida: pique alto e pega-pega - Nelson (7 anos). Fonte: Da autora.

As brincadeiras tradicionais comumente estão presentes na cultura escolar, conforme pesquisas de Machado (2013), Passos (2013) e Machado e Wiggers (2012). Estas se manifestam de maneira significativa durante a recreação, assim como em outros momentos de brincadeiras livres, como no pátio. Sobre essa evidência, Sarmento (2004) declara que a prática das brincadeiras tradicionais está arraigada na cultura da infância e as crianças que brincavam, quando adultas, compartilham essas experiências ao longo de gerações.

A quadra de esportes também é fortemente apontada como espaço de brincar preferido dentro da escola. Importante salientar que o momento de 
permanência na quadra faz parte do tempo de recreação, portanto, é um espaço bem concorrido, pois há muitas crianças. Dentre as produções, 13 desenhos consideraram a quadra como espaço predileto, e 100\% dessas representações consideram o futebol como brincadeira favorita.

Kaislan (6 anos) mostra o futebol jogado no espaço da quadra (figura 8) com muita riqueza: as traves e os limites demarcados arquitetam o espaço da quadra e do jogo. Os jogadores estão posicionados de maneira que ocupam toda área e um, em especial, está configurado com a bola apresentando uma impressão de movimento. Em seu relato, esse deslocamento é evidenciado: "um menino com a bola...esse aqui vai dar de bicicleta...esse aqui vai tocar pra esse fazer o gol" (Kaislan - 6 anos. DIÁRIO DE CAMPO, 30/04/2014, p.37).

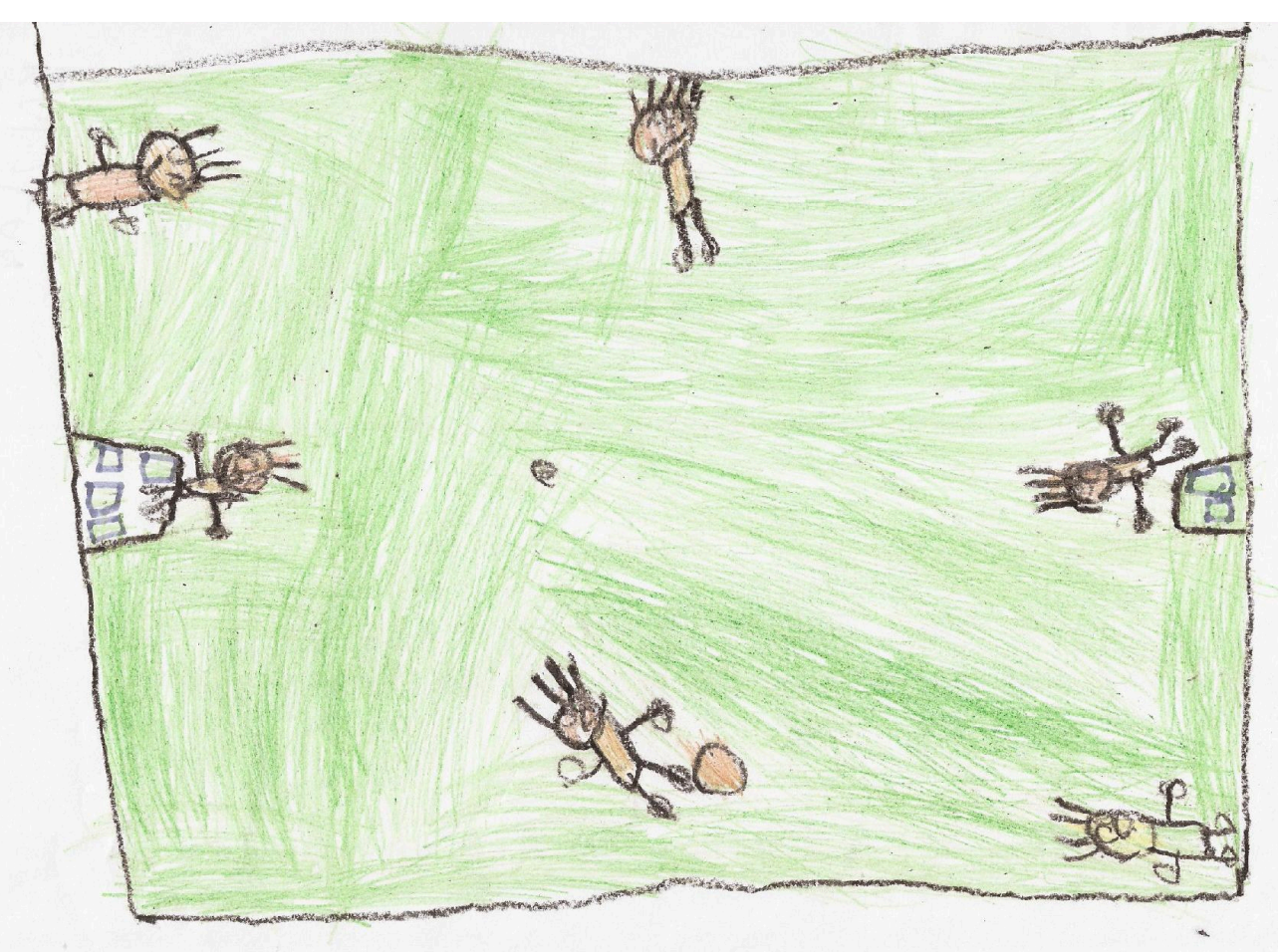

Figura 8: Minha brincadeira preferida: futebol - Kaislan (6 anos).

Fonte: Da autora. 
Em suma, as práticas corporais evidenciadas se caracterizavam como típicas do acervo da cultura infantil, como pular corda, pega-pega, pique alto, correr, saltar, fazer castelos de areia, inventar histórias e encená-las, cantarolar músicas, praticar esportes, dançar e outras mais (DIÁRIO DE CAMPO, 17/03/2014, 27/03/2014, 02/04/2014, 05/05/2014 e 23/05/2014).

\subsubsection{Saída}

$\mathrm{O}$ entardecer abre-se à despedida de um turno repleto de atividades. A saída se constituía em mais um ritual, no qual as crianças apenas poderiam deixar a sala de aula na presença dos responsáveis e, se estes não chegassem após o sinal das dezoito horas, as crianças os aguardavam junto da porteira da escola, na parte interna.

Um pouco antes da saída, as crianças que terminaram a última atividade de conteúdo pedagógico do dia, estão autorizadas a brincar ou ler revistinhas e livros, desde que permanecessem em seus lugares, a fim de não atrapalharem aqueles que ainda estivessem fazendo atividade. A princípio essa orientação é obedecida, mas logo percebemos movimentação nas mesas e corredores da sala, bem como movimentação na janela e porta da sala. As crianças pegam livros e revistas em quadrinhos para ler. Essas crianças que ficam sentadas lendo são as mesmas que realizam suas atividades sem circular pela sala. São consideradas pela professora os melhores alunos.

Outras, enquanto esperavam os responsáveis, divertiam-se com brinquedos particulares, especialmente no dia do brinquedo. De acordo com Pinheiro (2000), o brinquedo trazido de casa expressa um gosto singular, uma preferência que, geralmente tem relação estreita com a identificação da criança à sua realidade cotidiana. Ademais, ele é uma possibilidade social, permitindo a troca entre os colegas, na medida em que guarda algum segredo a ser ensinado ao parceiro da 
interação. Uma criança brinca com um carro e outro com uma moto. Brincam com massinha e pecinhas de brinquedo lego. Com esses brinquedos, confeccionavam vários objetos, criavam e representavam histórias. As crianças brincavam caminhando e correndo pela sala. Alguns meninos ainda brincaram de "jogo do bafo $9 "$ com cartinhas. Outras meninas praticavam brincadeiras "cantadas com as mãos" "10.

Esse momento de brincadeiras no horário da saída é bem significativo para algumas crianças, razão pela qual este aparece no desenho como sua brincadeira preferida. Davi (7 anos) (Figura 9) se desenha e relata gostar de brincar de pecinha montando pessoas. Em seu desenho, ele se retrata segurando pecinhas de montar enquanto observa a porta da sala, esperando seus familiares para ir embora da escola.

Minha brincadeira preferida é montar pessoas com pecinhas coloridas, brincar de pique esconde...de bola... e correr. Mas eu gosto mesmo é de no final da aula a tia deixar que a gente pegue um brinquedo enquando os pais chegam. Então todos os dias brinco de pecinha e no dia do brinquedo também (Davi - 7 anos. DIÁRIO DE CAMPO, 30/04/2014, p.39).

O brincar, segundo Oliveira (2002) é muito mais do que uma simples recreação, é uma das formas mais complexas que a criança tem de comunicar-se com o mundo, ou seja, o desenvolvimento acontece através de trocas recíprocas que se estabelecem durante toda sua vida. Assim, por meio da brincadeira a criança pode desenvolver capacidades importantes como a atenção, a memória, a

\footnotetext{
${ }^{9} \mathrm{O}$ jogo do bafo é uma brincadeira muito comum entre os colecionadores de figurinhas. Dois ou mais jogadores formam uma roda onde todos ficam sentados ao redor das figurinhas que estão sendo disputadas. A brincadeira se chama jogo do bafo, pois o bafo (vento) provocado pelas mãos durante a batida no monte de figurinhas vira as figurinhas. Deve-se bater nas figurinhas, seja com a mão completamente aberta ou com a mão levemente em "forma de concha". Disponível em: wikipedia.org/wiki/Jogo do bafo. Acesso 05 de janeiro de 2015.

${ }^{10}$ Souza (2009) define essa brincadeira como um jogo que envolve mímicas e outros gestos que se executam geralmente a partir de uma rima ou de uma canção. São brincadeiras onde os participantes recitam ou cantam versos e seguem o que está proposto na letra: mãos para cima, mãos ao lado, tocam o amigo, imitam bichos, viram de costas e tudo mais que o verso mandar. Para brincar é preciso ao menos dois participantes, mas é possível bater palmas em grupo ou em rodas.
} 
imitação, a imaginação, sem falar no desenvolvimento de áreas da personalidade, como afetividade, motricidade, inteligência, sociabilidade e criatividade.

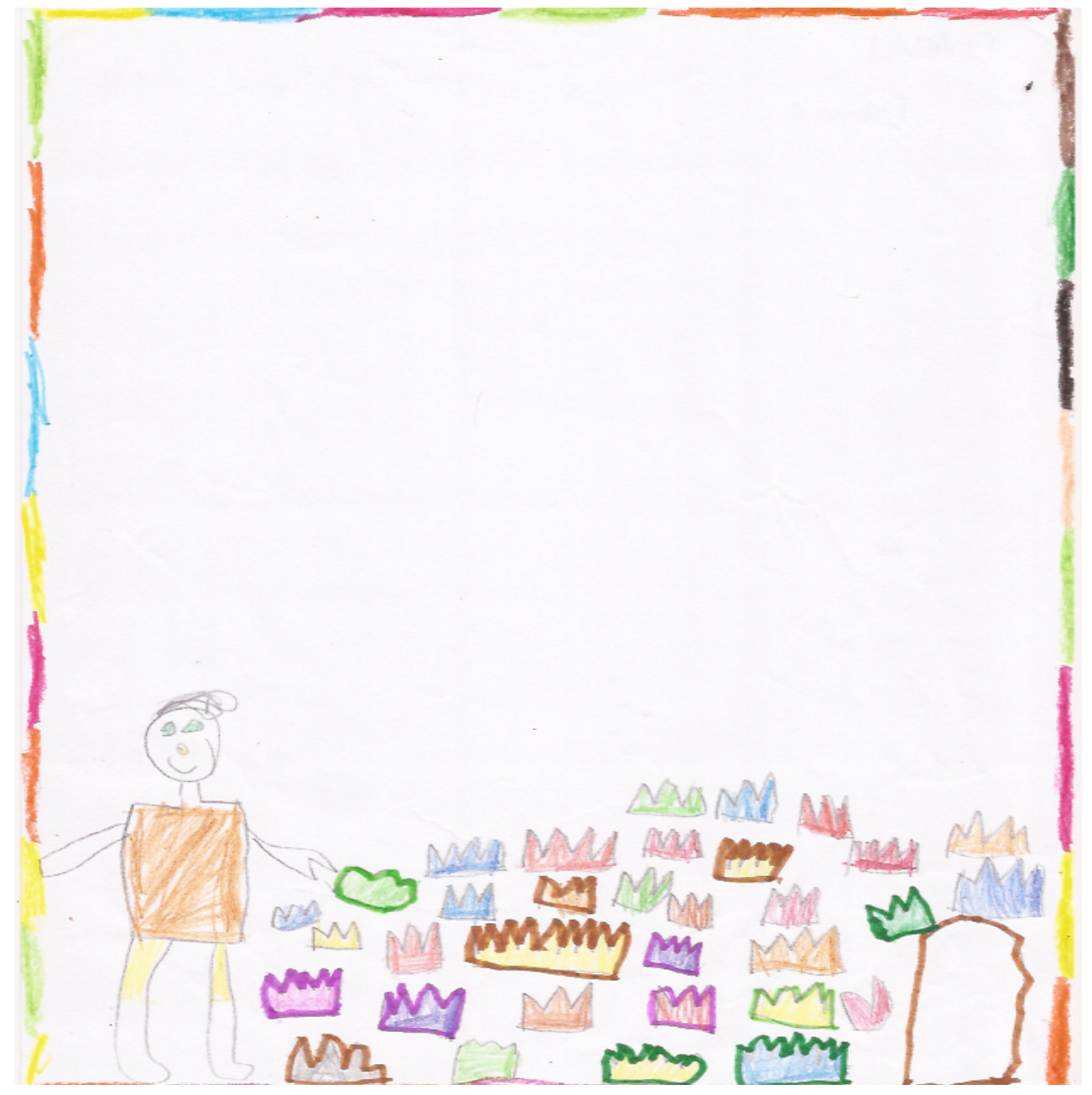

Figura 9: Minha brincadeira preferida: brincar com pecinhas - Davi (7 anos). Fonte: Da autora.

Depois de um tempo de brincadeiras, a professora chama à atenção de todos. Especialmente em um dia de observação, ela foi ao interruptor de luz e a desligou. Com a luz apagada, ela disse que daquele jeito não poderiam brincar, pois estavam atrapalhando os que ainda se encontravam desenvolvendo a atividade. Mandou então que todos se sentassem e brincassem em seus lugares. Por um instante, houve um silêncio na sala. Contudo, rapidamente as 
brincadeiras prosseguiram da maneira que havia se iniciado. A professora apenas foi para perto das duas crianças que ainda faziam atividade e as ajudou (DIARIO DE CAMPO, 12/05/2014, p. 42). Alguns conversavam bastante e em tom alto, outros conversavam mais sutilmente e outros aquietavam-se quando a professora chamava à atenção. Ou seja, assim como certas crianças respeitavam as normas, outras resistiam a elas de alguma forma, o que demonstra que a escola não obtinha o controle desejado. Isso era perceptível em vários momentos da rotina escolar.

Com a chegada dos responsáveis, a professora encaminhava as crianças para organizar seus pertences. Neste momento, observamos que a professora mantinha um diálogo com os pais acerca do rendimento e do comportamento dos pequenos. As devidas reclamações em relação ao mau comportamento de um ou outro eram feitas nesse momento, já que as reuniões pedagógicas com os pais são em número reduzido durante o ano.

\subsection{Mediações culturais}

As crianças estão envolvidas por um cotidiano repleto de expectativas, teorias, referenciais, parâmetros dos quais participaram ou não da sua elaboração. Dimensões culturais também fizeram parte do cotidiano da turma e se apresentaram como pontos de referência na construção de identidades. Denominou-se, neste trabalho, mediações culturais aspectos emergidos comuns às dinâmicas surgidas para além dos muros escolares, mas profundamente convergidas nesse ambiente.

\subsubsection{Dia do brinquedo}

Não é permitido trazer brinquedos todos os dias à escola, pois tal comportamento interfere diretamente na interação do dono do brinquedo e dos 
demais amiguinhos de grupo e nas atividades planejadas pela professora. Surgem conflitos, choro e frustrações. Brinquedo de casa diariamente na escola atrapalha, mas existe um dia específico em que ele é permitido (DIÁRIO DE CAMPO, 16/05/2014, p. 45). Semanalmente, às sextas-feiras, às crianças eram permitidas e estimuladas a levarem para escola um brinquedo. Não havia restrições do que poderiam levar. Durante um tempo de trinta a quarenta minutos, no início do turno, e mais quinze a vinte minutos no final da aula, as crianças eram autorizadas a brincar com seus objetos.

Considera-se brinquedo "[...] um objeto que a criança manipula livremente, sem estar condicionando às regras ou a princípios de utilização de outra natureza" (BROUGÈRE, 2000, p. 13). O brinquedo, então, pode ser definido como qualquer objeto que a criança utilizapara brincar, são "[...] objetos que dão suporte ao brincar [...]" (Brasil, 1998 p.71).

De acordo com a professora regente, o dia do brinquedo é um momento que os alunos aprendem a compartilhar, dividir e brincar coletivamente.

\begin{abstract}
Através do brincar elas exploram os seus limites e possibilidades. Brincando estão em constante processo de construção de significados buscando compreender o mundo através de suas representações. Trazer o "seu" brinquedo para a escola tem um significado especial: "eu trago" um pedacinho de mim, o que é "meu" e apresento, compartilho com meus colegas (DIÁRIO DE CAMPO, 16/05/2014, p.45).
\end{abstract}

Nessas ocasiões, as crianças costumavam apresentar um desfile de bonecas, roupinhas para vesti-las, bonecos de super heróis e montros, carrinhos, motos, aviões, arminhas, espadas, máscaras, animais de brinquedos, jogos de cartas, jogos de montar, jogo de pega varetas, joguinhos de cozinha (panelas, fogão, geladeira), massinhas tipo geleia (amoeba), computadores, tablets e celulares infantis de brinquedo. Destarte, parecia favorecer certas brincadeiras e interações. Um exemplo disto acontecia quando os meninos levavam superheróis para a sala de aula. Esta se transformava em um espaço de jogo de 
batalhas com sons e movimentos típicos dos desenhos e filmes dos heróis presentes. Ou quando as meninas levavam suas bonecas e brincavam de alimentá-las e arrumar a casa, e brincavam de 'familhinha' (DIÁRIO DE CAMPO, 23/05/2014, p. 53).

No registro gráfico de Hadassa (7 anos) - (figura 10). Hadassa se desenhou em um desses momentos que podia levar sua boneca para o parque. Esboçou-se, no parque, no brinquedo casinha de bonecas, representando o papel de mamãe e sua boneca, sua filhinha caminhando em direção à uma árvore para "apanhar frutinha" e juntas "cozinharem uma torta" (DIÁRIO DE CAMPO, 30/04/2014, p. 36).

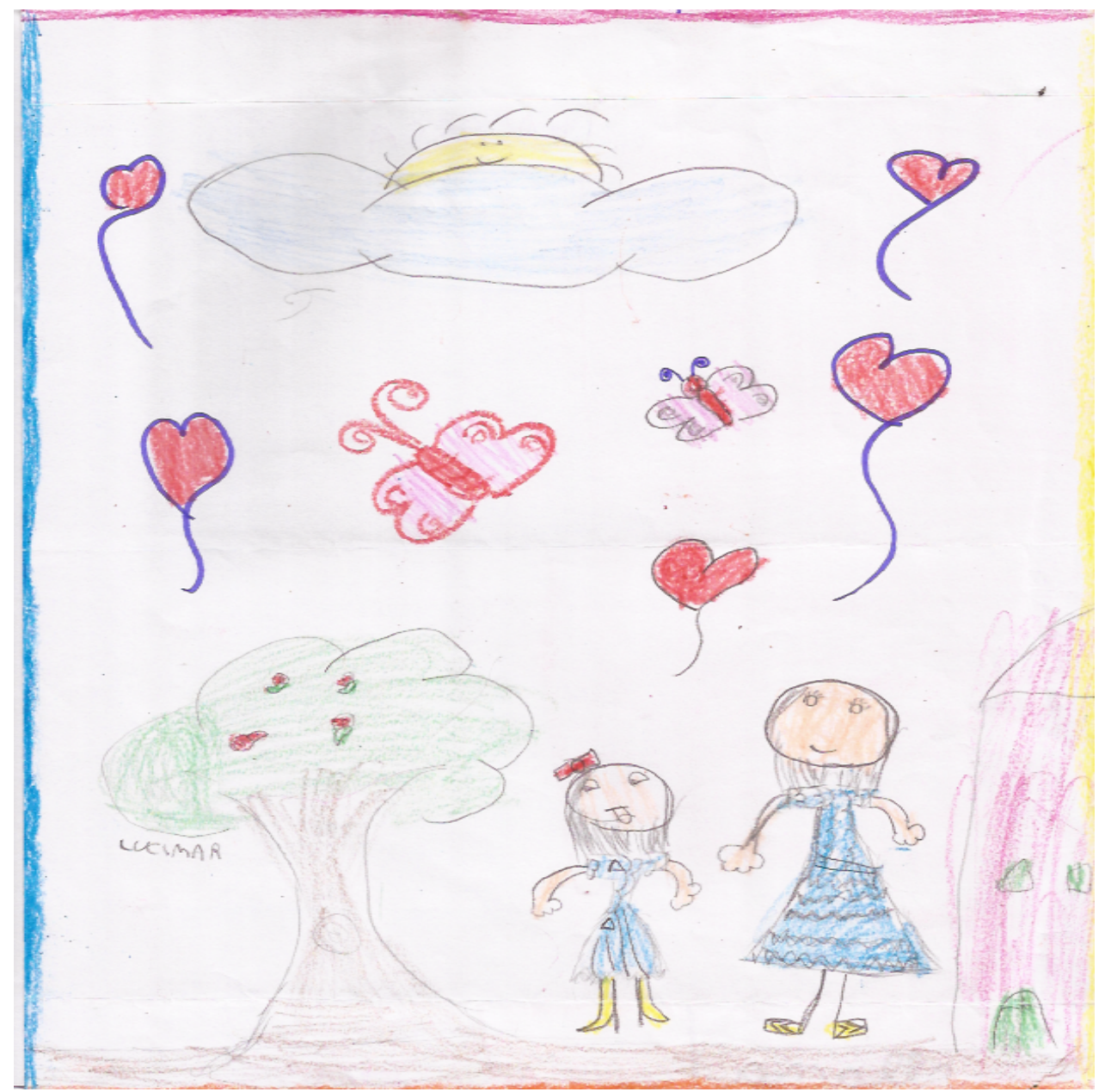

Figura 10: Minha brincadeira preferida: dia do brinquedo (mamãe e filhinha) - Hadassa (7 anos).

Fonte: Da autora. 
As brincadeiras denominadas por Corsaro (2002) de "faz de conta" fazem parte do processo de reprodução interpretativa das crianças. Esse autor refere-se ao brincar sociodramático no qual as crianças reproduzem e produzem colaborativamente atividades que estão relacionadas às suas experiências reais de vida por exemplo, rotinas familiares e ocupacionais (CORSARO 2002). Analisa também o brincar sociodramático como a "[...] atividade ou rotina mais valorizada na produção, organização e manutenção da cultura de pares" (CORSARO 2002, p. 32). A brincadeira, portanto, é caracterizada pela apropriação e ressignificação por parte da infância de valores e características da realidade em que se encontram.

Joãozinho (6 anos) - (figura 11) também retrata em seu desenho sua brincadeira preferida o dia do brinquedo, onde delineou em seus traços alguns carrinhos, bonecos super heróis encenando uma possível batalha, pois os bonecos aparecem pintados com armaduras de combate e, por fim, rascunhou um caminhão que segundo seu autor "é o carro do super máquina verde equipado com serras cortantes e cinco rodas pra ganhar mais velocidade na hora da luta" (Joãozinho - 6 anos. DIÁRIO DE CAMPO, 30/04/2014, p.38). 


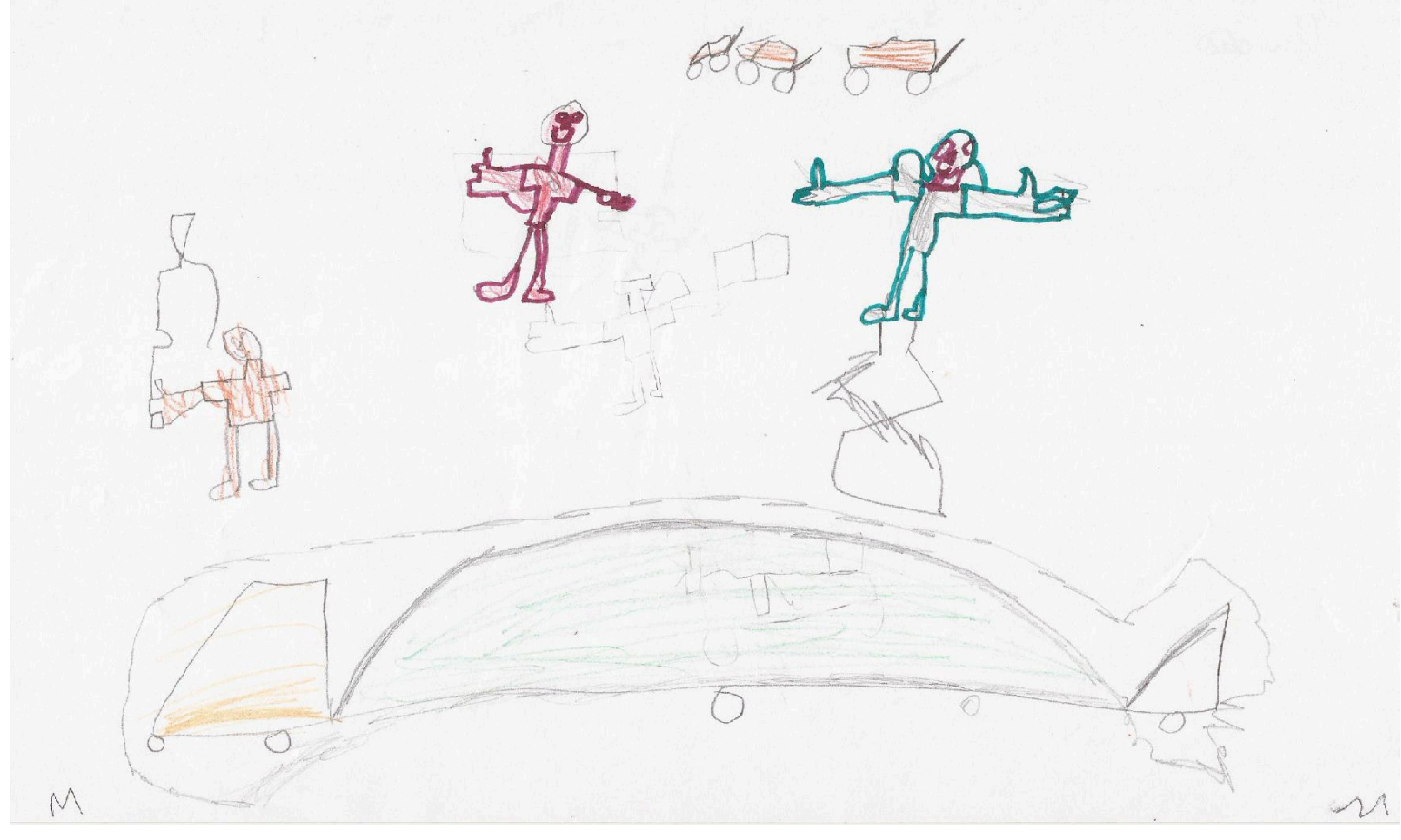

Figura 11: Minha brincadeira preferida: dia do brinquedo - Joãozinho (6 anos).

Fonte: Da autora.

De acordo com Brougère (2000), as expressões do brincar estão impregnadas de culturas diversas. Dessa forma, os brinquedos e brincadeiras não se limitam em si, elas integram aspectos externos que porventura possam lhes trazer influências. Neste caso, percebe-se a inspiração dos filmes e desenhos de super heróis. Verifica-se que atualmente as brincadeiras encontram-se guiadas e vão ao encontro de novos brinquedos, novas manipulações e representações. É fato que a cultura moderna tem no seu ínterim a mídia e, de modo especial, a televisão. Associado a essas idéias, Brougère (2000, p. 53) completa “[...] a televisão transformou a vida e a cultura da criança, as referências de que ela dispõe. Ela influenciou, particularmente, sua cultura lúdica".

\subsubsection{Presença da mídia}

A ação da mídia e do mercado de consumo são notórios e instigantes entre os sujeitos contemporâneos interpelando e subjetivando-os, instituindo modos de 
ser, agir e estar no mundo. Entre as crianças esta ação não é diferente. Afinal, as culturas de infância configuram-se em uma construção social e histórica, refletindo a sociedade em que se inserem e sendo atravessadas pelas marcas do seu tempo. Na contemporaneidade, estas marcas são apresentadas pela mídia e pelo mercado de consumo. Assistimos à constituição de um mercado global de produtos culturais para a infância, que são acompanhados por um grande incremento comercial, o qual busca incentivar o consumo entre o grupo social infantil. Mesmo participando de famílias de classe econômica mediana, algumas com condições econômicas bastante desfavorecidas, as crianças não deixam de consumir produtos midiáticos. Estes artefatos culturais são trazidos para dentro do espaço escolar pelas crianças e congregam desde material escolar e brinquedos, a músicas e formas de vestir e falar. Com a turma, constatou-se tal assertiva já no primeiro dia em campo. Os cadernos, mochilas, estojos de lápis e lancheiras, em sua maioria, estampavam gravuras de personagens de desenhos animados, novelas e filmes, bem como times de futebol.

Os objetos de consumo possuem uma textualidade. Esta textualidade veicula representações, na maioria das vezes sutis, sobre formas de ser e estar no mundo, que concorrem para a formação de identidades e subjetividades. Cantar e dançar de determinada forma, preferir determinado brinquedo, usufruir determinado bem, imitar o personagem do programa favorito significa possuir uma certa identidade, "estar dentro", "tornar-se um igual", participar de uma linguagem, ocupar um espaço social. Tais interpretações aparecem claramente nos discursos e nas representações gráficas das crianças.

Nelson: - tia advinha de que a gente tá brincando?

Pesquisadora: - de lutinha.

Nelson: - não. De mortal kombat.

Pesquisadora: - que brincadeira é essa?

Nelson: - 'peraí'.

Ele saiu correndo gritando pelo João. E depois de percorrerem toda a extensão da quadra o João responde: 
João: - é mortal kombat do jogo de video game que meu pai me ensinou. Também tem um filme, mas não assisti, pois é velho e só vou ver quando meu pai ver também (DIÁRIO DE CAMPO, 07/05/2014, p.40).

Esse trecho demonstra que tanto a mídia eletrônica, por meio do vídeo game, como a televisiva influenciou uma brincadeira em que as crianças imitavam golpes de luta. Para elas não eram simples golpes de luta e sim a reprodução e vivência do jogo de vídeo game que gostam, isto é, a oportunidade de se aproximarem com os personagens. Para uma das crianças, era mais que isso, era usufruir, por meio da história contada e dirigida pelo seu colega, de um brinquedo ao qual não tem acesso.

Já em outro momento, no dia do brinquedo, observou-se outra experiência de brincadeira que envolvia aspectos da cultura midiática. Ao chegar em sala, algumas crianças reunidas em volta da mesa da Ana, explorando vários adereços da boneca Barbie e de um boneco feito de massa de modelar dramatizando um casamento entre eles. Depois trocavam as roupas dos bonecos e encenavam um diálogo referente a uma situação cotidiana. "A gente brinca de 'familinha'. Ela está se arrumando pra procurar um emprego e as irmãs ficam com o bebê" (Camilla - 7 anos e Ana - 6 anos. DIÁRIO DE CAMPO, 23/05/2014, p.53).

Um brinquedo, neste caso específico a boneca Barbie ${ }^{11}$, apresentado mundialmente a partir de uma determinada visão pela publicidade: a boneca, ícone entre os brinquedos infantis dirigidos especialmente às meninas, em sua versão original, “[...] nunca foi uma cozinheira, mas já foi chef; nunca foi

\footnotetext{
${ }^{11}$ Boneca criada pela empresa americana Mattel na década de 1960, que encarna um modelo adolescente de mulher loura, alta, magra, com diferentes trajes e artefatos, que se tornou um ícone entre os brinquedos produzidos em escala mundial. Diante do sucesso que alcançou, a boneca já recebeu diversas representações temáticas, bem como se transformou em personagem de histórias em quadrinhos, livros e filmes infantis. Cabe destacar que muitas versões da boneca surgiram, embaladas pelo sucesso comercial da primeira, sendo produzidas por outras empresas e vendidas a preços menores do que o da boneca original, no comércio popular. A Barbie a que se referem as meninas cujas falas estão aqui apresentadas, faz parte destas versões.
} 
operária, mas já foi desenhista de moda; ela foi solista, uma estrela de rock e a mitológica fada dos dentes" (STEINBERG, 2001, p. 328). Contudo, apesar do esforço publicitário em apresentar o referido produto cultural a partir de uma idéia de glamour, na expectativa da manutenção e ampliação do consumo do mesmo, o imaginário infantil o transporta para diversas e diferentes situações, muitas delas, presentes no dia-a-dia das crianças que com ela brincam.

Se os produtos da indústria cultural direcionados ao público infantil ganham a simpatia das crianças pelo valor simbólico que estabelecem com elas, sua utilização por estes sujeitos é diferenciada. Sarmento ressalta que:

Uma das conclusões mais insistentemente afirmadas na análise da recepção dos produtos da indústria cultural pelas crianças, nomeadamente no que respeita aos programas televisivos, é de que, contrariamente ao que é correntemente veiculado pelo senso-comum, as crianças não são receptoras passivas, acríticas e reprodutivas desses produtos, mas, pelo contrário, ainda que se estabeleça uma relação empática, essa recepção é criativa, interpretativa e frequentemente crítica das respectivas mensagens [...] (SARMENTO, 2004).

A boneca/personagem Barbie aparece na mídia com possibilidades econômicas invejáveis, em meio à brincadeira infantil assume características locais, através das experiências vivenciadas e transportadas para as situações lúdicas pelas crianças que a manipulam. Evidencia-se, portanto, que somente a indústria cultural não é suficiente para objetivar as culturas infantis.

Em outros dois exemplos da influência televisiva permeando o imaginário infantil, destaca-se o apresso pelo esporte coletivo futebol, mais especificamente os times de futebol que são bem divulgados e expostos na mídia esportiva. Os desenhos de Neymar (6 anos) e Romeu (7 anos), respectivamente, mostram de maneira bem detalhada seu favoritismo pela prática do jogo de futebol.

No primeiro desenho (figura 12), Neymar (6 anos) aparece jogando futebol na escola com seus amigos, bem como assistindo ao jogo pela televisão e em um estádio. Observa-se, em seu desenho, a presença de cadeiras revelando 
um estádio de futebol e bandeiras de times retratando uma possível competição. Na parte superior, à direita do desenho, Neymar diz estar sentado no sofá de sua casa assistindo a uma partida de futebol transmitida pela TV. O nome fictício Neymar escolhido por essa criança também revela sua predileção por este esporte.

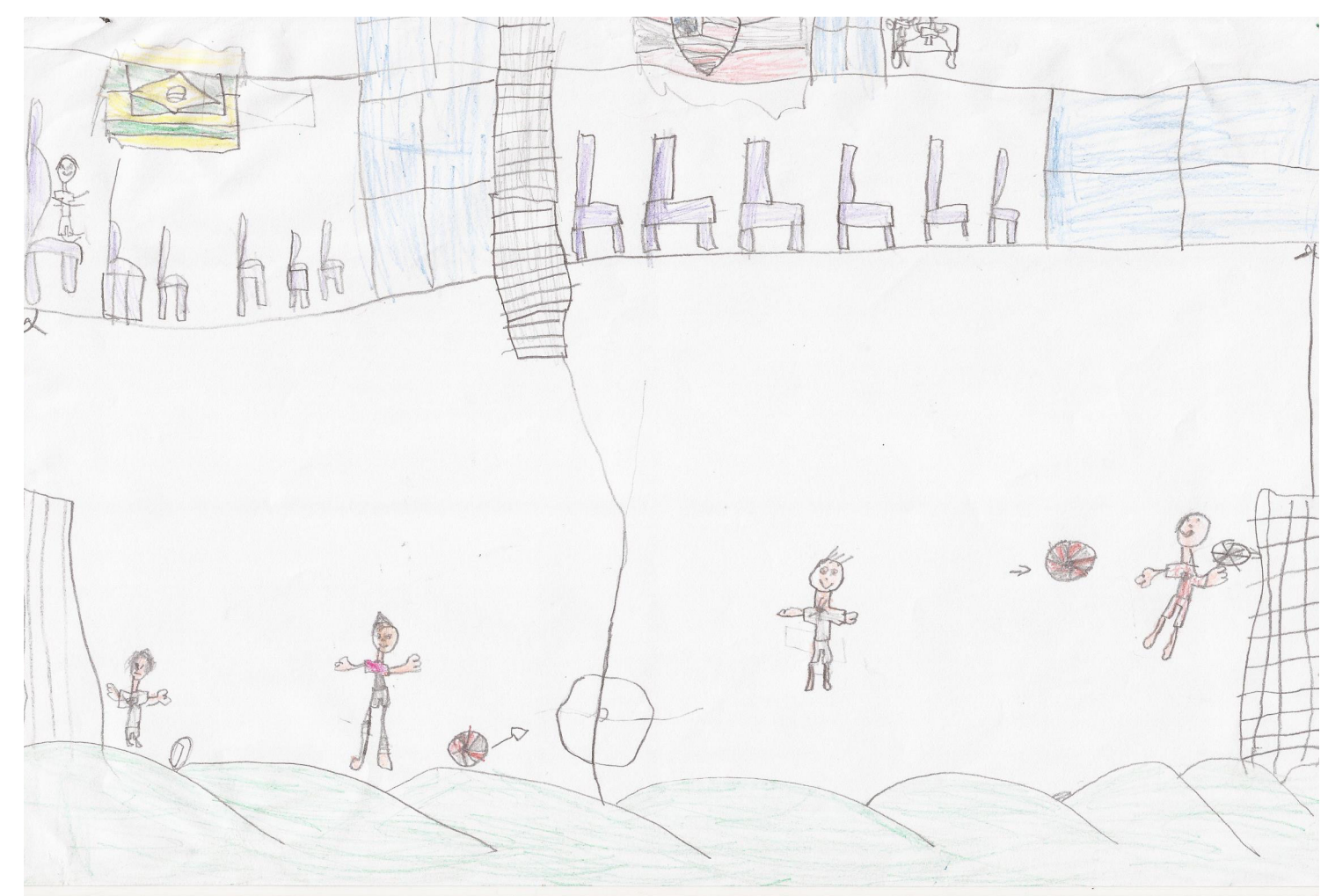

Figura 12: Minha brincadeira preferida: jogo de futebol - Neymar (6 anos).

Fonte: Da autora.

O desenho (Figura 13) e a nota de campo que apresenta a fala de Romeu (7 anos) também revela sua apreciação pelo jogo televisivo e pelo estádio de futebol. Em seu desenho aparecem vários jogadores, inclusive um dos jogadores é o Romeu, em um campo dentro de um estádio de futebol. Observam-se cadeiras e bandeiras de times retratando uma competição, tal como é transmitida pela televisão, já que em conversas foi revelado que o Romeu nunca havia ido a um jogo em estádio de futebol. 


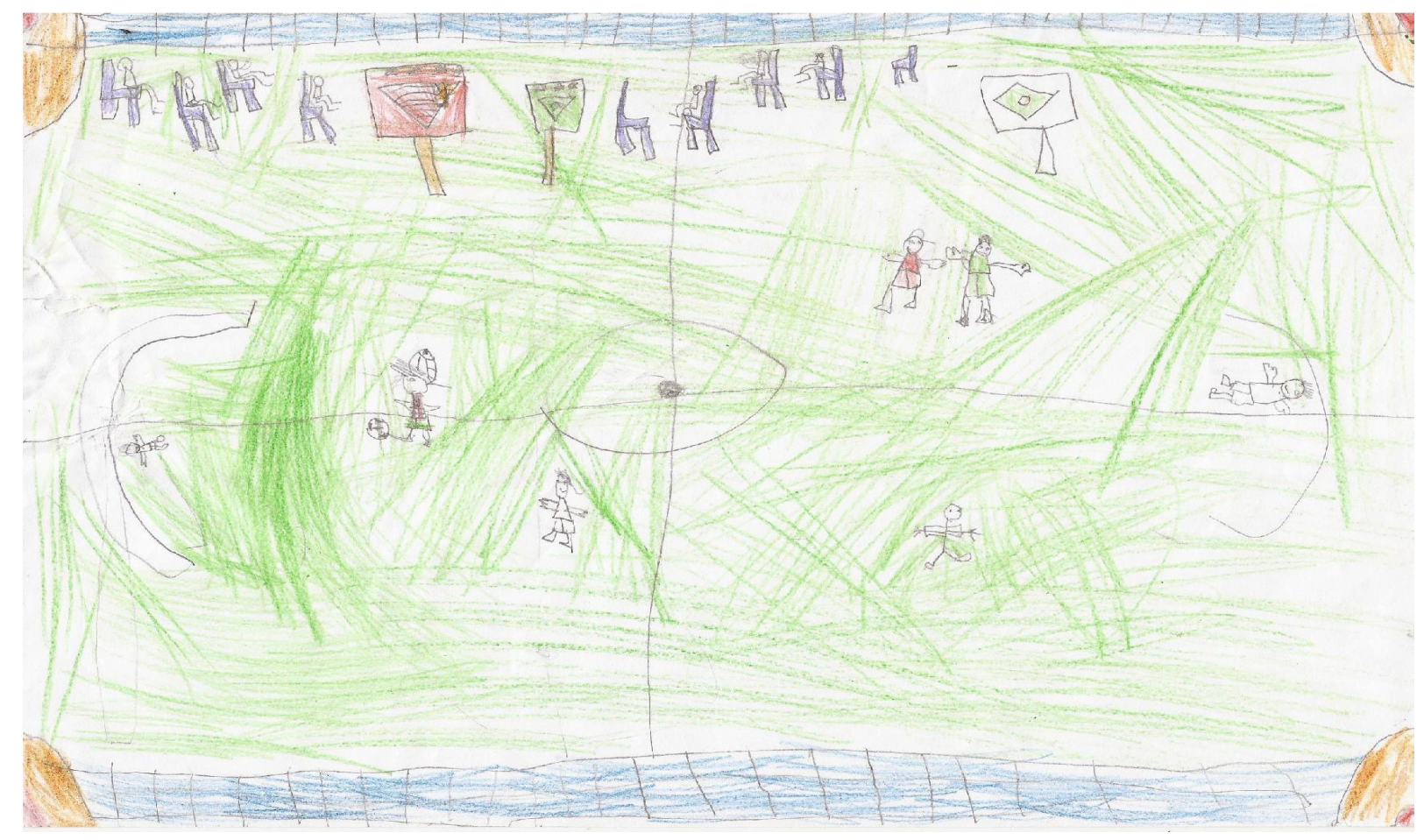

Figura 13: Minha brincadeira preferida: eu no estádio, torcendo para o flamengo - Romeu (7 anos).

Fonte: Da autora.

Minha brincadeira preferida é jogar futebol e torcer para o flamengo. Desenhei o campo de futebol e a cadeira do estádio com bandeiras de times. Meu time é o flamengo. Ele é maior time do Brasil. Queria que aqui na escola tivesse mais fuleco, porque ele joga um montão de bola. Gosto quando a professora chama a gente para o parquinho. Lá gosto do escorregador (Romeu - 7 anos. DIÁRIO DE CAMPO, 30/04/2014, p.37).

Especificamente nesses desenhos, evidenciou-se a televisão e o esporte como fatores motivacionais de suas brincadeiras preferidas. Quanto a essa evidência, Betti (1998) destaca o surgimento do que se denomina "esporte telespetáculo", fenômeno construído pela televisão. O esporte telespetáculo é uma realidade textual relativamente autônoma, construída pela mediação do olhar interessado das câmaras televisivas. Porém, há um sujeito especial, o telespectador, que experimenta as sensações do jogo de maneira quase passiva, mas nada o impede de transportar suas experiências para o campo real. Para essas crianças o fato de serem telespectadores parece lhes permitirem agregar 
movimentos corporais às suas brincadeiras de maneira que os tornam mais habilidosos durante o jogo de futebol na escola.

Diante das particularidades apresentadas nas falas e desenhos infantis, destacamos que a cultura lúdica infantil envolve diversos elementos, especialmente a mídia. Segundo Brougère (2000, p. 51), a cultura lúdica infantil é permeada por inúmeros aspectos "inclusive a mídia" que influencia os brinquedos e as brincadeiras e, “[...] para se tornar um verdadeiro objeto de brincadeira, deve encontrar seu lugar [...] na cultura lúdica infantil”. Em cada lugar a criança incorpora elementos da cultura para alimentar suas brincadeiras, e, portanto: "Seria inverossímil se a brincadeira da criança não se alimentasse da televisão e seus efeitos" (BROUGÈRE, 2000, p. 51).

Para Brougère (2000, p. 54), o "grande valor da TV para a infância é oferecer às crianças [...] uma linguagem única e comum", mesmo para aquelas que estão em ambientes distantes ou diferentes. A lembrança de um herói ou de um personagem de um desenho animado é suficiente para que as crianças comecem a brincar, regulando seus comportamentos e ações a partir de um conhecimento comum que têm do referido personagem ou desenho.

Observando as crianças entre seus pares, viu-se que muitos de seus brinquedos referem-se a um determinado personagem de desenho animado ou a um programa de televisão. A mídia, mais especificamente a televisão, faz parte da cultura e a criança é produto e produtora desta. Como nos alerta Benjamin (2002), a criança não é um ser isolado, separada do mundo e dos povos. Por isso assiste à televisão e diante dela e de seus produtos, produz cultura, conhecimento, interpretações de mundo. Sabemos que a mídia permite uma abertura ao outro, em que podemos escutar outras palavras e ver outras faces e lugares até então não acessíveis. 
Dessa forma, observou-se a influência da mídia na preferência das crianças em relação ao time de futebol, aos brinquedos e brincadeiras, assim como em relação a objetos de usos escolar. Porém, de acordo com Siqueira, Wiggers e Souza (2012); Machado e Wiggers (2012) e Passos (2013), a mídia influencia mas não determina as escolhas e as práticas corporais infantis. É possível perceber que mesmo trazendo a mídia para seu universo, a criança, para além da cultura midiática, lembra-se de outras brincadeiras que fazem parte do acesso popular. Nesse sentido, constata-se que as crianças são sujeitos sociais inseridos em uma cultura e também são produtoras de cultura.

Buckingham (2007), acredita que os meios de comunicação incentivam a criatividade e a criação de uma cultura coletiva, bem como debilitam as formas de regulamentação e controle. Isto é, a mídia permite às crianças serem autoras de seus próprios repertórios culturais escrevam em uma multiplicidade de formas distintas. Neste contexto, as limitações geográficas e as hierarquias sociais estabelecidas são enfraquecidas e deixam de atuar.

\subsubsection{A brincadeira como prática corporal essencial}

Conforme Sarmento (2004), a cultura infantil é fortemente marcada pela ludicidade que se materializa no brincar, compondo uma das atividades interativas de imensa significação para as crianças. Segundo Fonseca e Faria (2012), as brincadeiras são compreendidas como artefatos culturais e apresentam um conjunto de regras e significações que proporcionam o desenvolvimento e enriquecimento da criança. De acordo com Brougère (2000), há um movimento tanto interno quanto externo, através do qual a criança constrói sua cultura lúdica brincando. Na visão do autor, a brincadeira é forma de ação social que é produzida por uma cultura mais ampla e produz uma cultura lúdica específica. A 
brincadeira, portanto, é evidenciada pela apreensão e ressignificação por parte da infância de valores e aspectos da realidade em que se encontram.

Acerca dessa perspectiva, Borba (2007) destaca que o fato da criança estar situada num contexto social e histórico, ou seja, num ambiente estruturado a partir de valores e significados, incorpora a experiência social e cultural do brincar por meio das relações que estabelece com os outros, crianças e adultos. Ao brincar, a criança representa, imita, inventa, recria e reinterpreta o mundo, revelando-nos o que ela é, demonstrando seus sentimentos, como vê a si e aos outros.

Identificou-se, na pesquisa, que as brincadeiras se evidenciaram na totalidade dos desenhos e conversas, considerando um contexto de práticas corporais mais ou menos preferidas. Evidencia-se nos desenhos e falas das crianças, que o tempo e o espaço para as brincadeiras acontecem no momento da recreação no parque, como menciona Romeu ( 7 anos) ao ser perguntado em que momento da escola ele pode brincar: "Só no parquinho" (DIÁRIO DE CAMPO, 26/05/2014, p. 55).

Contudo, observa-se que as crianças da turma pesquisada brincam a todo o momento, em todos os espaços e de variadas brincadeiras. "Brincam com suas mochilas, com seus lápis de cores. Brincam em duplas ou sozinhas. Ficam um tempão apontando lápis na lixeira só para conversar com outra criança que também está em pé diante da lixeira. Fazem da mochila carrinhos, da tesoura, avião e da cadeira, balanço. Estojos de lápis simulam espadas para uma luta velada embaixo da mesa. Brincam de empurrar um ao outro na fila durante o trajeto de um espaço para o outro ou abaixam-se para brincar de cartinhas. As meninas apreciam bastante as brincadeiras cantadas com as mãos e todos, no dia do brinquedo, brincam com seus brinquedos trazidos de casa (DIARIO DE CAMPO, 10/04/2014, p.26). Consentidas ou não, as crianças brincam. 
Dentre os desenhos, percebe-se que os meninos gostam de brincadeiras esportivas e brincadeiras de combate, como futebol, brincar de arminha, guerrinha, polícia e ladrão e quase não brincam nos brinquedos do parque. Já as meninas preferem brincadeiras na casinha de bonecas, nos brinquedos do parque, pular corda, brincadeiras realizadas com as mãos e cantigas, porém não gostam muito das brincadeiras que envolvam correr pelo espaço, pois temem se machucarem ou se sujarem. A brincadeira livre ganha importância como um fim em si mesma. Ao analisar os desenhos das crianças, observa-se que na escola pesquisada as brincadeiras assumem lugar de destaque em suas ações.

Conforme observamos no desenho (Figura 14), Alice (6 anos) se diverte nos brinquedos do parque, pois é o momento que mais gosta dentro da rotina escolar e no outro lado da folha retrata o que menos gosta de fazer: outra brincadeira, já mencionada anteriormente, "polícia e ladrão". Alice (6 anos) se desenha fugindo de outra criança, dentro da casinha de bonecas, que insiste em apontar para ela uma arminha que simulou com as próprias mãos. 


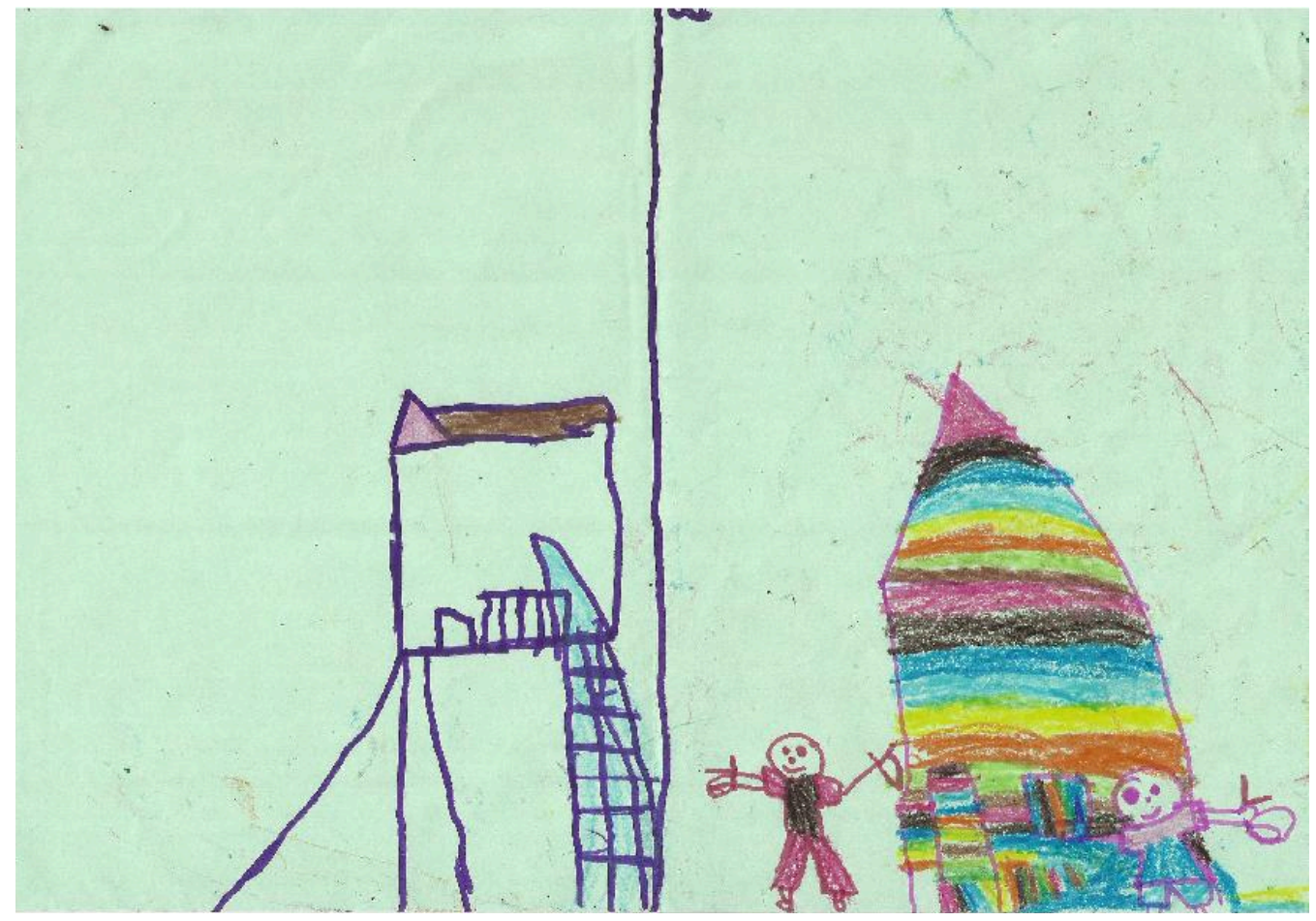

Figura 14: O que mais gosto de fazer na escola e em que lugar e o que menos gosto de fazer na escola e em que lugar: -"Mais gosto de brincar no parque e não gosto dos meninos brincando de arminha, eles pisam na lama e jogam em cima de mim" - Alice (6 anos).

Fonte: Da autora.

Entende-se, portanto, que brincar não é uma atividade simples, que ocorre naturalmente bastando duas ou mais crianças se juntarem Ao contrário, envolve um complexo processo de construção e de negociação entre os pares, porém, constitui um momento privilegiado para a construção de suas identidades e culturas. De acordo com Borba (2006, p. 75), o brincar é entendido como a síntese das culturas infantis, "[...]cooperando, divergindo e negociando, reproduzindo, criando e partilhando significados, conhecimentos e regras e, sobretudo, se reconhecendo como membros de um grupo de pares."

Brincar, para Carvalho (1998), é viver criativamente e se faz em quase todos os momentos da vida. Pelo brincar a criança experimenta a sua relação com o outro e com o mundo, aprende a se relacionar com ele. Não é um simples 
gesto mecânico, mas movimento dotado de intencionalidade, de significados, de emoção, de expressão e movimento contextualizado culturalmente.

No desenho (Figura 15), realizado por Lucas (06 anos), percebemos uma especificidade vivenciada muitas vezes pelas crianças-alunos. Lucas o desenha e relata em sua fala o que mais gosta de fazer na escola: brincar de futebol na quadra com seus amigos. Observa-se tal relato na primeira parte do desenho. Todavia, na segunda metade da folha observamos que a criança se desenhou com aspecto facial de tristeza ao observar os demais amigos brincarem no parque e ele olhando sem poder brincar, pois estava de castigo.

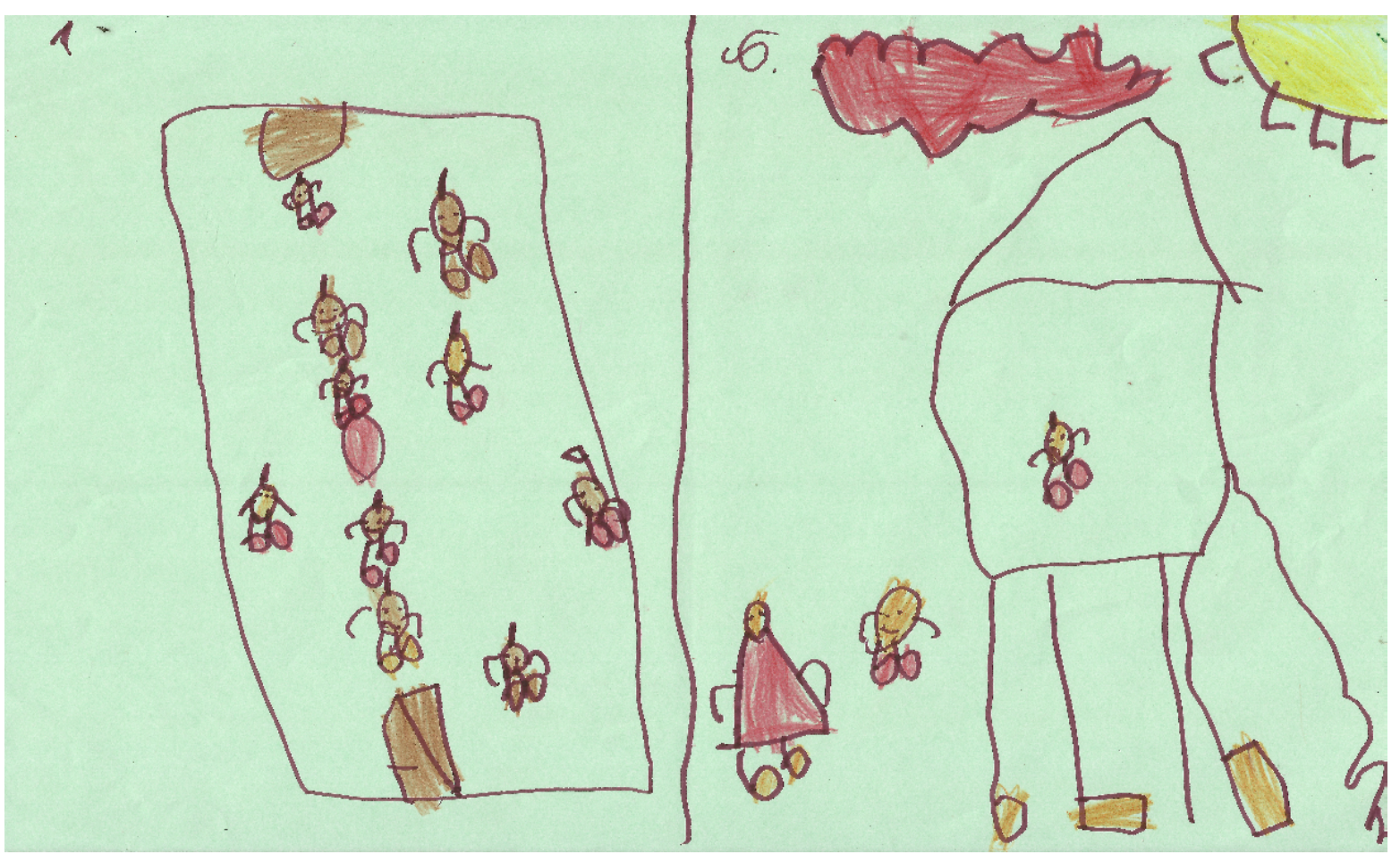

Figura 15: O que mais gosto de fazer na escola e em que lugar e o que menos gosto de fazer na escola e em que lugar: -"Eu mais gosto de futebol e menos gosto de pique pega e de ficar olhando os colegas brincar e não brincar" - Lucas (6 anos).

Fonte: Da autora.

É comum encontrarmos crianças cumprindo castigo imposto pela professora por não observarem as regras impostas tanto por ela, quanto pela escola. Constatamos em nossas observações de campo, que o corpo é submetido 
a controle e disciplinarização à medida em que transgride às normas estabelecidas. A criança, no ambiente escolar tradicional, é confinada a aceitar o que o adulto determina. Elas devem seguir aos comandos e rotinas préestabelecidas. Richter e Vaz (2005) enfatizam que no momento de fuga às regras, o corpo passa a ser objeto de disciplinamento e é nesse momento que a criança passa a ser aluno e está condicionada às punições estabelecidas.

Elias (1994) aponta que controlar as manifestações do corpo foi um fator essencial no processo de civilização do homem. Ademais, salienta que as diversas culturas foram responsáveis por agregar regras de boas maneiras ao corpo na tentativa de frear desejos e sensações próprias do ser humano. Sobre tais proposições, Sacristán (2005, p. 70) complementa.

Uma das acepções de estar educado é o ser educado, o se comportar (ao menos publicamente) com boas maneiras; estas são ritos que querem mostrar aos demais disposições internas para com eles, o controle de emoções, da agressividade, para mostrar certas disposições, etc.

Quando uma criança se desenha em situação de castigo ela nos revela que o processo de escolarização faz parte do processo civilizatório e contribui sobremaneira para a formação de concepções e identidade sobre ser aluno. Diante disso, observa-se que as crianças vão aos poucos modificando suas ações a partir de sua entrada e permanência na escola. Interiorizam as obrigações que são impostas e por sua vez os movimentos espontâneos vão sendo moldados e quando fogem às regras destacam a punição como algo desgostoso.

Para Foucault (2007), essa penalidade hierarquizante na escola tem como objetivo classificar os alunos segundo as suas aptidões e o seu comportamento e exercer, ainda, sobre eles, uma pressão constante para que sigam todos o mesmo modelo, se sujeitem à subordinação, sejam dóceis e disciplinados. Não pretendese aqui enfatizar que regras não são necessárias, mas promover reflexões sobre a criança e os espaços escolares, no intuito de percebermos outros caminhos para 
as crianças enfrentarem essa passagem dos primeiros anos escolares com mais satisfação e sem traumas.

Considerando o brincar como a atividade essencial da infância. Vejo na brincadeira uma atividade, que também pode ser pedagógica, de grandes potencialidades para este encontro, entre estas diferentes racionalidades, a adulta e a infantil. Reitero aqui a importância de planejar e organizar o tempo e o espaço da escola de forma que os meninos e meninas que ali passam parte do seu dia, tenham o seu direito à brincadeira garantido, com muitos e diversos brinquedos e que estes estejam acessíveis, inteiros, limpos, disponibilizados de forma criativa e convidativa. 


\section{CONSIDERAÇÕES PARA ESTE TEMPO E ESPAÇO}

Essa pesquisa teve como objetivo identificar e analisar as práticas corporais de crianças, considerandos os tempos e epaços escolares em uma escola pública do Distrito Federal. Após o caminho percorrido, algumas iquietações foram amenizadas e outras aparereceram, pois percebeu-se a contante transformação e reconfiguração das infâncias.

Em um contexto amplo as práticas corporais são entendidas "como fenômenos que se mostram, prioritariamente, em âmbito corporal e que se constituem como manifestações culturais" (SILVA et al, 2009, p. 20). Faria e Vidal (2000) revelam que tempos e espaços escolares operam como uma espécie de discurso que instituem, em sua materialidade, um sistema de valores, um conjunto de aprendizagens sensoriais e motoras e uma semiologia que recobre símbolos estéticos, culturais e ideológicos. Por isso, os padrões dos tempos e dos espaços podem afirmar ou negar saberes e culturas, além de estimular ou restringir diferentes formas de linguagens, expressividades e interações das quais o corpo humano é dotado.

No cotidiano da pesquisa, percebeu-se a organização dos tempos e espaços mediante às necessidades de controle das atividades e do comportamento das crianças. Em determinados espaços, as crianças estão à vontade, em outros, na maioria das vezes, se encontram disciplinarizadas, em fila ou imóveis em seus lugares. Os tempos seguiram a mesma perspectiva, tempos de brincadeiras, de recreação e principalmente tempos reservados para alfabetização por meio da leitura, da escrita, bem como do controle disciplinar. Em alguns momentos ouvem-se conversas e barulhos, em outros, exige-se o absoluto silêncio. As crianças, por sua vez, ocupam os tempos e os espaços e por meio deles e neles se relacionam, com seus corpos sempre em movimento, criam, reinventam e transgridem as funções pré-estabelecidas, [...] "afirmando um corpo sempre 
vivo, presente, ativo." (MACHADO, 2013, p.178). Esse misto de ordenamento estrutural e corporal são espontâneos das crianças e se fizeram presentes nos tempos e espaços da escola.

As práticas corporais não estão isentas de signos ideológicos e os tempos e espaços escolares, segundo Vinão Frago (2001) não são dimensões neutras da educação. Ao contrário, constituem corporeidades dos sujeitos escolares, impondo por sua materialidade uma determinada aprendizagem sensorial e motora, bem como disseminavam símbolos estéticos, culturais e ideológicos. "[...] os espaços para a educação não pertencem ao mundo da mecânica, com 'precisão e regularidade, normalização e racionalização', mas ao mundo dos seres vivos" (VINÃO FRAGO, 2001, p.137). Desta maneira, entendemos que a escola é o local privilegiado para o reconhecimento da pluralidade cultural e para o exercício da cidadania ativa, desde que a produção simbólica realizada pelas crianças a partir dos modos específicos de interpretação do mundo seja valorizada, considerando seu real potencial de intervenção social.

E muitos contextos às crianças são atribuídos papéis diferentes: na casa, o papel de filho, irmão ou irmã; na escola, o papel de aluno, devendo cumprir padrões de imobilidade, disciplina e também padrões de movimentos e práticas corporais. Galardini (1996) destaca que o espaço e o modo como é organizado resulta sempre em ideias e saberes das pessoas que nele habitam. Portanto, o espaço de serviço voltado para as crianças traduz a cultura da infância, a imagem da criança, dos adultos que o organizam. Trata-se de uma poderosa mensagem do projeto educativo concebido para esse grupo de crianças.

A rigidez e organização do tempo e espaço escolar formatado não atendem às particularidades dos sujeitos do cotidiano, ampliando muitas vezes somente a quantidade de tempo, enquanto a qualidade é posta em segundo plano. A uniformidade presente na organização escolar é apontada negativamente por 
Gòmez (2004), pois não se leva em conta o contexto social no qual a instituição está inserida. Esse tempo e esses espaços pedagógicos são fragmentados por meio das atividades balizadas pelo calendário como: os períodos festivos e comemorativos, avaliações, planejamentos, reuniões, entre outros.

Organizar o cotidiano das crianças pressupõe pensar que o estabelecimento de uma sequência básica de atividades diárias pode ser, antes de mais nada, o resultado da leitura que fazemos do nosso grupo de crianças, a partir, principalmente, de suas necessidades. No que se refere à organização das atividades, são necessários momentos diferenciados, planejados de acordo com as necessidades biológicas, psicológicas, sociais e históricas das crianças.

Fonseca e Faria (2012) destacam que a escola é o lugar em que a cidadania, com evidência na participação infantil, pode ser desenvolvida desde que professores e gestores reconheçam as competências das crianças devendo ocorrer segundo os modos de vida delas próprias, suas culturas e alteridade. É preciso, portanto, que os adultos entendam que as crianças são sujeitos sociais inseridos em uma cultura e dessa maneira também são produtoras de cultura. À escola presta-se refletir criticamente seus currículos, medidas disciplinares, tempos e espaços em diálogo com os elementos da cultura lúdica, como a brincadeira, ouvindo a criança e permitindo-lhe que participe da tecitura de seus saberes. Com efeito, Barbosa e Horn (2001) propõem que a organização dos tempos e espaços seja feita a partir da observação daquilo que é objeto de brincadeira das crianças, como elas se desenvolvem, as preferências delas, bem como o contexto sociocultural no qual a proposta pedagógica está inserida.

A brincadeira como prática corporal essencial, na concepção das crianças, foi evidenciada pela observação em campo e pelos desenhos por elas realizadas, conjugados com as conversas acerca dos mesmos. A produção de desenhos e as conversas fizeram parte da triangulação de técnicas utilizadas, juntamente com a 
observação participante. A produção de desenhos e conversas visaram potencializar as crianças como produtoras dos dados. Pretendeu-se assim evidenciá-las como atores principais da pesquisa, permitindo expressarem suas percepções em papel, por meio de seus grafísmos.

Ao nos aproximarmos da escola pesquisada registramos diferentes práticas corporais realizadas pelas crianças nos tempos e espaços estruturados pelos adultos. Evidenciou-se por meio das observações e desenhos que as crianças brincam a todo momento e consideram momento da recreação, o parque e a quadra de esportes espaços de referência para esse brincar autorizado e livre. A rotina revelou uma série de ações que ocorrem em paralelo e são invisíveis e inaudíveis para quem pretende ver somente a dimensão opressora da realidade. Os próprios corpos se revelaram menos dóceis do que imaginávamos e as crianças circulavam, autorizadas ou não, pelos tempos e pelos espaços da escola.

Para Bracht (2009), ao estudar a organização de um currículo que considere as práticas corporais da criança na escola, o sentido da prática pedagógica deve "[...] sair da formação de um indivíduo funcionalizado e adaptado aos valores dominantes, para a formação de um indivíduo capaz de situar histórica, social, cultural e politicamente as práticas [...]", ou seja, promover a formação de cidadãos e sujeitos construtores de cultura. Dessa forma, entendemos que a escola é o local privilegiado para o reconhecimento da pluralidade cultural e para o exercício da cidadania ativa desde que a produção simbólica realizada pelas crianças a partir dos modos específicos de interpretação do mundo seja valorizada, considerando seu real potencial de intervenção social. 


\section{REFERÊNCIAS}

AMORIM, Kátia de Souza; VITORIA, Telma, ROSSETTI-FERREIRA, Clotilde. Rede de Significações: perspectiva para análise de inserção de bebês em creche. Cadernos de Pesquisa, $n^{\circ}$ 109, p. 115-144, 2000.

ARIÈS, Philippe. História social da criança e da família. 2. ed. Rio de Janeiro: Guanabara, 1981.

BALABAN, Nancy. O início da vida escolar: da separação à independência. Porto Alegre: Artes Médicas, 1988.

BARBOSA, Maria Carmem; HORN, Maria da Graça Souza. Organização do espaço e do tempo na educação infantil. In: CRAIDY, Carmem; KAERCHER, Gladis (Orgs.)s Educação Infantil: pra que te quero? Porto Alegre: Artmed, 2001.

BENJAMIN, Walter. Reflexões: a criança, o brinquedo, a educação. São Paulo: Summus, 2002.

BELLONI, Maria Luiza. Infância, Máquinas e violência. Educ. Soc. Campinas, v.25, n.87, p. 575-598, 2004.

BETTI, Mauro. A janela de vidro: esporte, televisão e Educação Física. Campinas: Papirus, 1998.

BOGDAN, Robert; BIKLEN, Sari. Investigação qualitativa em educação: uma introdução à teoria e aos métodos. Porto: Porto, 1994.

BORBA, Ângela Meyer. As culturas da infância nos espaços-tempos do brincar: estratégias de participação e construção da ordem social em um grupo de crianças de 4-6 anos. In: ANPED, 2006, Caxambu - Minas Gerais.

O brincar como um modo de ser e estar no mundo. In: BRASIL Ensino Fundamental de nove anos: orientações para a inclusão da criança de seis anos de idade. Brasília: Ministério da Educação, Secretaria da Educação Básica, 2007. p. 33-45.

BRACHT. Valter. Formação profissional: currículo e prática pedagógica. XVI Conbrace e III Conice. Anais... Salvador, 2009.

BRASIL. Ministério da Educação e do Desporto. Referencial curricular 
nacional para a educação infantil.Vol.1. Brasília: MEC/SEF, 1998.

BRASIL. Ministério da Educação. Secretaria de Educação Básica. Parâmetros Básicos de Infraestrutura para Instituições de Educação Infantil. Brasília: MEC/SEB, 2006.

BROUGÈRE, Gilles. Brinquedo e Cultura. São Paulo: Cortez, 2000.

BUCKINGHAM, David. Crescer na Era das Mídias. São Paulo: Loyola, 2007.

BUSS-SIMÃO, Márcia. Crianças, infâncias, educação e corpo. Papeles de Trabajo sobre Cultura, Educación y Desarrollo Humano, v. 3, p. 01-20, 2007.

. Antropologia da criança: uma revisão da literatura de um campo em construção. Revista Teias, Rio de Janeiro, v. 10, n. 20, p. 1-16, 2009.

. A dimensão corporal entre a ordem e o caos- Espaços e tempos organizados pelos adultos e pelas crianças. In: ARROYO, Miguel G.; SILVA, Maurício Roberto da (Orgs.). Corpo infância: exercícios tensos de ser criança por outras pedagogias do corpo. v. 1. Petrópolis, RJ: Vozes, 2012.

BUSS-SIMÃO, Márcia; ROCHA, Eloísa Acires Candal. Crianças, infâncias, educação e corpo. Nuances: estudos sobre educação, v. 14, n. 15, p. 185-204, 2007.

CAPARELLI, Sérgio. A emergência da criança no espaço do consumo. In: GARCIA, C. et all (Orgs). Infância, cinema e sociedade. Rio de Janeiro: Ravil, 1997.

CARVALHO, Nazaré Cristina. O brincar, a cultura da criança e a escola: possibilidades na educação física escolar. Dissertação (Mestrado em Educação) Universidade Metodista. Piracicaba. São Paulo, 1998.

CARVALHO, Alexandre Filordi de; MÜLLER, Fernanda. Ética nas pesquisas com crianças: uma problematização necessária. In: MÜLLER, Fernanda (Org.). Infância em perspectiva: políticas, pesquisas e instituições. São Paulo: Cortez, 2010 .

CASTELlANI, Lino Filho. Pelos meandros da Educação Física. Revista Brasileira de Ciências do Esporte, Maringá, v. 14, n. 3, p. 119-125, 1993. 
CORSARO, Willian. A reprodução interpretativa no brincar ao "faz de conta" das crianças. Educação, Sociedade e Culturas, n. 17, p. 113-134, 2002.

. Estudos das crianças e da infância. In: CORSARO, Willian. Sociologia da infância. Porto Alegre: Artmed, 2011.

DAOLIO, Jocimar. Da cultura do corpo. Campinas, SP: Papirus, 1995.

DAYRELL, Juarez. Múltiplos Olhares sobre Educação e Cultura. Belo Horizonte: UFMG, 1996.

DELGADO, Ana Cristina Coll , MÜLLER, Fernanda. Infâncias e crianças: ainda incógnitas para nós adultos/as? Cadernos de Educação, n.23, p. 177-195, 2006.

DEBORTOLI, José Alfredo Oliveira. Reflexões sobre as crianças e a educação de seus corpos no espaço-tempo de Educação Infantil. Paidéia, Belo Horizonte, v. 5, n4, p. 79-112, 2008.

ELIAS, Norbert. O processo civilizador: Uma história dos costumes. Rio de Janeiro: Jorge Zahar Ed., 1994.

. Sobre o tempo. Rio de Janeiro: Jorge Zahar Editor, 1998.

ESCOLANO, Augustín; VIÑAO, AntonioFrago. Currículo, Espaço e Subjetividade: a arquitetura como um programa.Rio de Janeiro: DP\&A, 2001.

FARIA FILHO, Luciano Mendes de.; VIDAL, Diana Gonçalves. Os tempos e os espaços escolares no processo de institucionalização da escola primária no Brasil. Revista Brasileira de Educação, Rio de Janeiro, v. 14, n. 14, p. 19-34, 2000.

FERNANDES, Florestan. As "Trocinhas" do Bom Retiro. Pro-posições, Campinas, v. 15, n.1(43), p. 229-250, 2004.

FERREIRA, Maria Manuela Martinho. "- A gente aqui o que gosta mais é de brincar com os outros meninos!" - as crianças como atores sociais e a (re) organização social do grupo de pares no cotidiano de um Jardim de Infância. Tese (Doutorado em Ciências da Educação) - Universidade do Porto. Porto. Portugal, 2002. 
FONSECA, Adriana de Castro; FARIA, Eliete do Carmo Garcia Verbena. Práticas corporais infantis e currículo - Ludicidade e ação no cotidiano e escolar. In: ARROYO, Miguel G.; SILVA, Maurício Roberto da (Orgs.). Corpo infância: exercícios tensos de ser criança por outras pedagogias do corpo. v. 1. Petrópolis, RJ: Vozes, 2012.

FONTANA, Roseli Cação. De que tempos a escola é feita? In: VIELLA, Maria dos Anjos Lopes, (Org). Tempos e espaços de formação. Santa Catarina: Argos; 2003.

FOUCAULT, Michel. Vigiar e punir: história da violência nas prisões. Petrópolis, RJ: Vozes, 2007.

FRANCISCO, Zenilda Ferreira. “Zê, tá pertinho de ir pro parque?" o tempo e o espaço do parque em uma instituição de educação infantil. Dissertação (Mestrado em Educação). Universidade Federal de Santa Catarina. Florianópolis, 2005.

FRIEDMANN, Adriana. O universo simbólico da criança: olhares sensíveis para a infância. Petrópolis, RJ: Vozes, 2005.

GALARDINI, Anna Lia. Lugares para crescer: projetos e experiências nos serviços pré-escolares na Itália. In: Anais do IV Simpósio Latino-Americano sobre Educação de Crianças de 0 a 6 anos e II Simpósio Nacional de Educação Infantil. Brasília, 1996.

GARCIA, Sylvia Gemignani. Folclore e sociologia em Florestan Fernandes. Tempo Social: Rev. Sociol., v. 13, n. 2, p. 143-167, 2001.

GÉLIS, Jacques. A individualização da criança. In: CHARTIER, Roger; ARÍES, Philippe (Orgs.). A história da vida privada III: da Renascença ao Século das Luzes. São Paulo: Companhia das Letras, 1991.

GHIRALDELLI, Paulo Junior. Pedagogia e Infância em tempos neoliberais. In: GHIRALDELLI, Paulo Junior. (Org.). Infância, Educação e neoliberalismo. São Paulo: Cortez, 1996.

GOMES, Zélia Fernanda Fonseca. Desenho Infantil - Modos de interpretação do mundo e simbolização do real. Um estudo em Sociologia da Infância. Dissertação (Mestrado) - Universidade do Minho. Braga, 2009. 
GÓMEZ, Encarna Sato. Outros tempos para outra escola. Revista Pedagógica Pátio, Porto Alegre, n.30, p.47-50, 2004.

GOBBI, Marcia Aparecida. Desenho infantil e oralidade: instrumentos para pesquisas com crianças pequenas. In: FARIA, A. L. G.; DEMARTINI, Z. B. F.; PRADO, P. D. (Orgs.). Por uma cultura da infância: metodologia de pesquisas com crianças. Campinas, SP: Autores Associados, 2002.

GONÇALVES, Rita de Cássia Pacheco. Arquitetura escolar:a essência aparece. Fábrica e escola confundem-se no desenho da Polivalente. Dissertação (Mestrado em Educação). Universidade Federal de Santa Catarina. Florianópolis, 1996.

GONÇALVES, Maria Augusta Salin. Sentir, pensar e agir: corporeidade e educação. v. 1. 15. ed. Campinas, SP: Papirus, 2011.

HALL, Edward. A Dança da Vida: a outra dimensão do Tempo. Lisboa: Relógio d'água, 1996.

JAVEAU, Claude. Criança, infância (s), crianças: que objetivo dar a uma ciência social da infância? Educação e Sociedade, Campinas, v. 26, n. 91, p. 379-389, 2005.

LE GOFF, Jacques. Para um novo conceito de idade média: tempo, trabalho e cultura no ocidente. Estampa, 1979.

LIMA, MayumiWatanabe de Souza. A cidade e a criança. São Paulo: Nobel, 1989.

LÜDKE, Menga; ANDRÉ, Marli Eliza Dalmazo Afonso de. Pesquisa em educação: abordagens qualitativas. São Paulo: EPU, 1986.

LOURO, Guacira Lopes. Prefácio. In:COUTO, Edvaldo Souza; GOELLNER, Silvana Vilodre (Orgs). O triunfo do corpo: polêmicas contemporâneas. Petrópolis: Vozes, 2012.

MACHADO, Sheila da Silva; WIGGERS, Ingrid Dittrich. Imagens da infância: mídias e suas representações em práticas corporais infantis. In: Pensar a Prática. Goiânia.v. 15, p. 966-984, 2012. 
MACHADO, Sheila da Silva. Vivo ou Morto? O corpo sob olhares de crianças. Dissertação (Mestrado em Educação Física) - Faculdade de Educação Física. Universidade de Brasília. Brasília, 2013.

MARTINS FILHO, Altino José. Jeitos de ser criança: balanço de uma década de pesquisas com crianças apresentadas na Anped. In: MARTINS FILHO, Altino José; PADRO, Patrícia Dias (Org.). Das pesquisas com crianças à complexidade da infância. 1. ed. São Paulo: Autores Associados, 2011.

MASCIOLI, Suselaine Aparecida Zaniolo. A corporeidade infantil edificada por tempos e espaços escolares. Revista Ibero-Americana de Estudos em Educação, v. 7, p. 155-164, 2012.

MAUSS, Marcel. Sociologia e Antropologia.Trad. de Lamberto Puccinelli. São Paulo: EPU, 1974.

MINAYO, Maria Cecília de Souza. O desafio da pesquisa social. In: DESLANDES, Suely Ferreira; GOMES, Romeu; MINAYO, Maria Cecília de Souza. (Orgs.). Pesquisa Social: teoria método e criatividade. Petrópoli: Vozes, 2010.

MONTANDON, Cléopâtre. Sociologia da Infância: balanço dos trabalhos em língua inglesa. Caderno de Pesquisa, FCC, n. 11, São Paulo, p. 33-60, 2001.

. As práticas educativas parentais e a experiência das crianças. Educ. Soc., Campinas, v. 26, n. 91, p. 485-507, 2005.

MUNAKATA, Kazumi. Educação e modernidade: sob as figuras do relógio e da tipografia ${ }^{\circ}$ Educar, Curitiba, n.18, p.43-52. 2001.

OLIVEIRA, Veras Barros. O brincar e a criança do nascimento aos seis anos. Petrópolis:Vozes, 2002.

OLIVEIRA, Nara Rejane Cruz de. Concepção de infância na Educação Física brasileira: primeiras aproximações. Revista Brasileira de Ciências do Esporte, Campinas, v. 26, n. 3, p. 95-109, 2005.

PASSOS, EliaRaquel Alves Portella. A mídia nas entrelinhas da cultura corporal infantil. Dissertação (Mestrado em Educação Física) - Universidade de Brasília. Brasília, 2013. 
PEDRERO-SANCHEZ, Maria Guadalupe. História da Idade Média - Textos e testemunhas. São Paulo: UNESP, 2000.

PEREIRA, Bárbara Elisa; NASCIMENTO, Maria Letícia Barros Pedroso. De objetos a sujeitos de pesquisa: contribuições da Sociologia da Infância ao desenvolvimento de uma etnografia da educação de crianças caiçaras. Educação, v. 21, p. 1-19, 2011.

PINHEIRO, Maria do Carmo Morales. "Quietinho, sentado obedecendo a professora". A representação do corpo da criança na pré-escola.Dissertação (Mestrado) - Faculdade de Educação. Universidade Federal de Goiás. Goiânia, 2000 .

PINTO, Maria Raquel Barreto. Tempo e espaços escolares: o (des) confinamento da infância. In: CARVALHO, Diana de; QUINTEIRO, Jucirema(Orgs.). Participar, brincar e aprender: exercitando os direitos das crianças na escola. v. 1. Araraquara, SP: Junqueira \&Marin Editores, 2007.

PINTO, Manoel; SARMENTO, Manoel Jacinto (Coords.). As crianças: contextos e identidades. Braga: Universidade do Minho, 1997.

QUINTANA, Mario. Caminho. Disponível em http://marioquintana.blogspot.com.br/2002_08_01_archive.html. Acesso em 23 de abril de 2015.

QVORTRUP Jens. A infância enquanto categoria estrutural. Educação e Pesquisa, v. 36, n.2, p. 631-643, 2010.

RICHTER, Ana Cristina; VAZ, Alexandre Fernandez. Corpos, saberes e infância: um inventário para estudos sobre a educação do corpo em ambientes educacionais de 0 a 6 anos. Revista Brasileira de Ciências do Esporte, Campinas, v. 26, n. 3, p. 79-93, 2005.

SACRISTÁN, José Gimeno. O aluno como invenção. Porto Alegre: Artmed, 2005.

SAINT-EXUPÉRY. Antoine. O pequeno príncipe. AGIR, 2002.

SARMENTO, Manoel Jacinto. As Culturas da Infância nas Encruzilhadas da 
Segunda Modernidade. In: SARMENTO, M. J.; CERISARA, A. B. Crianças e Miúdos: perspectivas sociopedagógicas da infância e educação. Porto, Portugal: Asa Editores, 2004.

SILVA, Ana Márcia. Das práticas corporais ou porque "Narciso" se exercita. RBCE, v.17, n. 3, p. 244-251, 1996.

SILVA, Ana Márcia; DAMIANI, Iara Regina. As práticas corporais e os elementos do processo metodológico da pesquisa integrada. In: (Orgs.). Práticas corporais: trilhando e compar (trilhando) ações em educação física. v. 1. Florianópolis: Nauemblu Ciência \& Arte, 2005.

SILVA, Maurício Roberto da. O corpo das crianças em movimento: apontamentos provisórios sobre a cultura corporal na Educação Infantil. Múltiplas Leituras, v. 3, p. 136-163, 2010.

SILVA, Ana Márcia et al. Corpo e experiência: para pensar as práticas corporais. In: José Luiz Cirqueira Falcão, Maria do Carmo Saraiva (Orgs.). Práticas Corporais no contexto contemporâneo: (in) tensas experiências. Florianópolis, Copiart, 2009.

SIROTA, Régine. Emergência de uma sociologia da infância: evolução do objeto e do olhar. Cadernos de Pesquisa, s/v, n. 112, p. 7-31, 2001.

. As delícias de aniversário: uma representação da infância. Trad. de Rosária Cristina Costa Ribeiro. Revista Eletrônica de Educação. São Carlos, SP: UFSCar, v.2, no. 2, p. 32-59, 2008. Disponível em http://www.reveduc.ufscar.br. Acesso em 22 de abril de 2015.

SIQUEIRA, Antonio Jorge. As representações do corpo na idade média. Vivência, n.37, p. 49-58, 2011.

SIQUEIRA, Isabelle Borges; WIGGERS, Ingrid Dittrich; SOUZA, Valeria Pereira de. O brincar na escola: a relação entre o lúdico e a mídia no universo infantil. In: Revista Brasileira de Ciências do Esporte. Campinas, v. 34, n. 2, p. 64-79, 2012.

SOARES, Carmen Lúcia. Corpo, conhecimento e educação: notas esparsas. In: SOARES (Org.). Corpo e história. Campinas: Autores Associados, 2001. 
. Práticas Corporais: Invenção de pedagogias? In: SILVA, Ana Márcia; DAMIANI, Iara Regina (Orgs.). Práticas corporais: gênese de um movimento investigativo em educação física. v. 1. Florianópolis: Nauemblu Ciência \& Arte, 2005.

. Educação do corpo. In: GONZÁLEZ, Fernando Jaime; FENSTERSEIFER, Paulo Evaldo(Orgs.). Dicionário Crítico de Educação Física. Ijui: Editora UNIJUI, p. 219-225, 2014.

SOUZA, Fernando. Os jogos de mãos: um estudo sobre o processo de participação orientada na aprendizagem musical infantil. Dissertação (Mestrado em Música) - Universidade Federal do Paraná, Curitiba, 2009.

STEINBERG, Shirley. A mimada que tem tudo. In: STEINBERG, Shirley.; KINCHELOE, Joe. Cultura infantil: a construção corporativa da infância. Tradução de George Eduardo Japiassú Brício. Rio de Janeiro: Civilização Brasileira, 2001.

THOMPSON, Edward. Tempo, disciplina de trabalho e capitalismo industrial. In: . Costumes em comum. São Paulo: Cia das Letras, 1998.

VEIGA-NETO, Alfredo. Espaços, tempos e disciplina: as crianças ainda devem ir à escola? In: CANDAU, Vera Maria. Linguagem, espaços e tempos no ensinar e aprender. Rio de Janeiro: Dpea, 2000.

VIELLA, Maria dos AnjosLopes. Entre relógios e ritmos: a experiência do tempo no cotidiano dos professores. In: VIELLA, Maria dos Anjos Lopes, (Org). Tempos e espaços de formação. Santa Catarina: Argos; 2003.

VIÑAO FRAGO, Antônio. Do espaço escolar e da escola como lugar: propostas e questões. In: ESCOLANO, Augustín; VIÑAO FRAGO, Antônio. Currículo, espaço e subjetividade: a arquitetura como programa. Rio de Janeiro: DP\&A Editora, 2001.

WIGGERS, Ingrid Dittrich. Corpos desenhados: olhares de crianças de Brasília através da escola e da mídia. Tese (Doutorado em Educação) -Universidade Federal de Santa Catarina. Florianópolis, 2003. 


\section{ANEXO I - Descrição das crianças - $1^{\circ}$ ano "G"}

\begin{tabular}{|c|c|}
\hline Nome $^{12}$ e idade & Descrição \\
\hline $\begin{array}{c}\text { Junior } \\
\text { (sete anos) }\end{array}$ & $\begin{array}{l}\text { Pele morena, cabelo preto e liso. Em sala de aula conversa bastante, } \\
\text { sorri muito, brinca durante a atividade. A professora sempre chama a } \\
\text { sua atenção por brincar muito em sala de aula. A brincadeira preferida } \\
\text { é jogar bola. É muito carinhoso. Em todos os dias da minha presença } \\
\text { em sala ele me abraçava, beijava e me conduzia a todos os espaços. } \\
\text { Mora com a avó e não tem irmãos. }\end{array}$ \\
\hline $\begin{array}{c}\text { Gabriela } \\
\text { (seis anos) }\end{array}$ & $\begin{array}{l}\text { Pele e olhos claros, cabelo enrolado. Um pouco tímida, mas sempre } \\
\text { brinca e conversa com o João. Demora em realizar as atividades. } \\
\text { Brinca no parque com colegas de outra sala e é bem amiga do Davi. } \\
\text { Sempre o defende durane os conflitos em sala de aula. Mora com a } \\
\text { mãe e avó e tem um irmão de noves meses, ao qual ela se refer-se a } \\
\text { todo momento. }\end{array}$ \\
\hline $\begin{array}{c}\text { João } \\
\text { (sete anos) }\end{array}$ & $\begin{array}{l}\text { Pele morena, cabelo com corte arrepiado, imitando alguns jogadores de } \\
\text { futebol. Conversa bastante. Demonstra um raciocínio bem rápido e por } \\
\text { isso, as vezes não tem paciência com as perguntas dos seus colegas. } \\
\text { Em muitos casos, trata os colegas com grosseria e fala alguns palavrões } \\
\text { e os agride com tapas. Admira a profissão do pai que é policial e possui } \\
\text { dois irmãos. }\end{array}$ \\
\hline $\begin{array}{c}\text { Rychard } \\
\text { (seis anos) }\end{array}$ & $\begin{array}{l}\text { Pele clara, pequenino, tímido, mas sempre em contato com seus } \\
\text { colegas. Demonstra prazer em realizar as atividades escolares e sempre } \\
\text { esboça um sorriso para a professora quando lhe chama. Na recreação } \\
\text { prefere as brincadeiras de corrida e pega-pega. Durante esse momento } \\
\text { sempre brinca com seu irmão gêmeo que estuda na outra sala. Mora } \\
\text { com seus pais e irão gêmeo. }\end{array}$ \\
\hline $\begin{array}{c}\text { Lucas } \\
\text { (seis anos) }\end{array}$ & $\begin{array}{l}\text { Pele clara, cabelos lisos. Muitas vezes demonstra tristeza em seu olhar } \\
\text { e não participa muito das atividades que exige reprodução em voz alta, } \\
\text { porém não para sentado na cadeira e muitas vezes dorme em sala. Não } \\
\text { carrega em sua mochila todos os materiais disdáticos necessários e a } \\
\text { todo momento está na mesa de algum colega pedindo algo emprestado. } \\
\text { Relata que a mãe esquece de colocar os materais na mochila. É um } \\
\text { pouco lento na execução das tarefas referentes a conteúdos didáticos, } \\
\text { porém durante a recreação brinca mais de correr e futebol. Mora com a }\end{array}$ \\
\hline
\end{tabular}

\footnotetext{
${ }^{12}$ Para preservar a idoneidade, por questões éticas, durante as conversas com as crianças solicitou-se que cada uma escolhesse um nome fictício para que fossem identificadas nos desenhos e em sua falas. Em alguns casos, devida a repetição de nomes, em especial àqueles que optaram por nome de ídolos do futebol, sugeriu-se que colocasse um diminutivo ou algum prenome ou sobrenome.
} 


\begin{tabular}{|c|c|}
\hline & $\begin{array}{l}\text { mãe, avó e dois irmãos. Durante o turno contrário da escola participa } \\
\text { de projetos sociais no INAV }{ }^{13} \text {. }\end{array}$ \\
\hline $\begin{array}{l}\text { Neymar } \\
\text { (seis anos) }\end{array}$ & $\begin{array}{l}\text { Pele morena, cabelo liso, porém o penteia de maneira que fique } \\
\text { arrepiado para parecer com seu ídolo do futebol. Usa óculos, mas relata } \\
\text { sentir-se desconfortável com isso, pois ninguém mais em sua turma } \\
\text { usa. Bem extrovertido, está sempre conversando e a professora sempre } \\
\text { chama a sua atenção, pois demora a realizar as atividades. Brinca mais } \\
\text { de jogar bola com outros meninos e não aceita que meninas entrem na } \\
\text { quadra para jogar junto. Mora com seus pais e mais um irmão. }\end{array}$ \\
\hline $\begin{array}{c}\text { Graziela } \\
\text { (seis anos) }\end{array}$ & $\begin{array}{l}\text { Pele morena clara, sorridente e carinhosa. Não conversa muito durante } \\
\text { as atividades e na hora da recreação só quer brincar com uma amiga da } \\
\text { outra turma. Gosta de pular corda. Em todo momento da minha } \\
\text { presença na escola quis me acompanhar e demonstrava ciúmes quando } \\
\text { outras crianças se aproximavam. Sempre me pedia para escrever em } \\
\text { meu caderno de anotações. Mora com pais e irmãos. }\end{array}$ \\
\hline $\begin{array}{c}\text { Bart } \\
\text { (seis anos) }\end{array}$ & $\begin{array}{l}\text { Pele morena e cabelos lisos bem escuros. Durante as aulas formava } \\
\text { junto com João, Junior, Jogador Neymar e Nelson um grupinho para } \\
\text { realizar as atividades em sala, conversar e brincar de futebol. } \\
\text { Demonstra muito empenho em realizar as atividades propostas pela } \\
\text { professora e em ajudar os demais colegas. Mora com pais e dois irmãos } \\
\text { e uma irmã. }\end{array}$ \\
\hline $\begin{array}{c}\text { Mateus } \\
\text { (sete anos) }\end{array}$ & $\begin{array}{l}\text { Pele morena clara, cabelos pretos e penteado arrepiado. Conversa } \\
\text { muito, mas faz as atividades. Tem uma voz bem potente. Tem seis } \\
\text { irmãos e sempre comenta com alegria sobre esse aspecto de sua } \\
\text { estrutura familiar, bem como da padaria que sua famiíla possui. É bem } \\
\text { carinhoso e gosta de brincar no escorregador. É seu primeiro ano na } \\
\text { escola e diz que a família não está adptada a cidade. }\end{array}$ \\
\hline $\begin{array}{c}\text { Davi } \\
\text { (sete anos) }\end{array}$ & $\begin{array}{l}\text { Pele clara, cabelos claros. Parece um pouco tímido, quase não conversa } \\
\text { com seus colegas. Se interessa bastante pelas conversas e brincadeiras } \\
\text { em sala com a Gabriela. Porém, sempre esteve disposto em conversar } \\
\text { quando eu perguntava alguma coisa. Tem cinco irmãos e mora somente } \\
\text { com a mãe. Gosta de brincar no parque. }\end{array}$ \\
\hline
\end{tabular}

13 O Instituto Nair Valadares - INAV é uma instituição sem fins lucrativos criada com a missão de promover educação, cultura, esporte, saúde e lazer, as crianças e adolescentes oriundos da comunidade local que se encontram em situação de risco e vulnerabilidade social. Buscam contribuir para o aprimoramento social, prestando serviços na área da educação, saúde e assistência social, valorizando desta forma, a pessoa humana na integração das crianças e adolescentes na sociedade sem discriminação econômica, política, religiosa ou racial. Atende 459 crianças e adolescentes na faixa etária de 3 a 14 anos de idade. Sua sede está localizada na cidade de Riacho Fundo II/DF. Fonte: http://www.inav.org.br 


\begin{tabular}{|c|c|}
\hline $\begin{array}{c}\text { Renato } \\
\text { (sete anos) }\end{array}$ & $\begin{array}{l}\text { Pele morena, corte de cabelo baixo. É bem conversador. Gosta de jogar } \\
\text { bola na hora da recreação. Faz atividades com certa dificuldade. Gosta } \\
\text { de participar do grupinho formado pelas crianças João, Junior, Jogador } \\
\text { Neymar, Nelson e Bart, porém nem sempre é aceito pelo grupo e } \\
\text { recorre a professora para intervir. Muitas vezes recorreu a mim. Mora } \\
\text { com a família de oitos pessoas, entre pai, mãe, irmãos e tios. }\end{array}$ \\
\hline $\begin{array}{c}\text { Hadassa } \\
\text { (sete anos) }\end{array}$ & $\begin{array}{l}\text { Pele morena clara e cabelo preto e longo. Não conversa durante muito } \\
\text { durante a aula. Tem a Camilla como uma de suas melhores amigas. } \\
\text { Senta sempre na primeira cadeira e é bem aplicada em suas tarefas. Em } \\
\text { todas as atividades que faz desenha no verso da folha dizendo que ama } \\
\text { o pai, a mãe e a professora. Gosta de brincar de corda e correr no } \\
\text { gramado. Demonstra muito interesse em aspectos da religião de sua } \\
\text { família, inclusive em explicar algumas tragédias asssisitidas na } \\
\text { televisão e em reprovar algumas atitudes de outras crianças. }\end{array}$ \\
\hline $\begin{array}{c}\text { Ana } \\
\text { (seis anos) }\end{array}$ & $\begin{array}{l}\text { Pele morena e cabelos encaracolados. Sempre vem a escola de vestido, } \\
\text { devido a opção religiosa de sua família. Senta na primeira cadeira da } \\
\text { fileira. Não é muito conversadeira e apresenta dificuldades em realizar } \\
\text { as tarefas. Brinca mais nos brinquedos do parque. Muitas vezes, fica } \\
\text { após o horário do término das atividades esperando alguém para buscá- } \\
\text { la. Mora com a mãe, tia e irmã. }\end{array}$ \\
\hline $\begin{array}{c}\text { Camilla } \\
\text { (sete anos) }\end{array}$ & $\begin{array}{l}\text { Pele morena clara, cabelos castanhos escuros encaracolados. Senta em } \\
\text { uma cadeira atrás da Hadassa, a quem considera ser sua melhor amiga. } \\
\text { É bastante carinhosa com a professora e conversa bastante com todos } \\
\text { da sala. É muito aplicada na realização das atividades. Apresenta } \\
\text { características de liderança e por isso impõe tarefas a todos da sala na } \\
\text { ausência da professora. Brinca mais de pular corda, correr e estrelinha. }\end{array}$ \\
\hline $\begin{array}{c}\text { Alice } \\
\text { (seis anos) }\end{array}$ & $\begin{array}{l}\text { Pele morena e cabelo castanho escuro crespos e que muitas vezes está } \\
\text { liso por processo químico ou de tranças. Senta na primeira cadeira. } \\
\text { Parece bem tímida. Não brinca e nem conversa com muito na sala de } \\
\text { aula. Apresenta bastante dificuldade em realizar as atividades. Costuma } \\
\text { brincar nos aparelhos do parque. Mora com a mãe e tia que sempre } \\
\text { vem busca-la, porém nunca no horário indicado. }\end{array}$ \\
\hline $\begin{array}{c}\text { Vitorya } \\
\text { (seis anos) }\end{array}$ & $\begin{array}{l}\text { Pele morena clara e cabelo castanho, liso e curto. É bem entrosada com } \\
\text { as outras crianças. Às vezes levanta de sua cadeira para passear na sala. } \\
\text { Realiza as atividades, mas gosta de conversar com os colegas. Brinca } \\
\text { mais de correr, estrelinha com sua amiga da outra sala e gosta do } \\
\text { parque. Mora com pais e duas irmãs e um irmão. }\end{array}$ \\
\hline $\begin{array}{c}\text { Felipe } \\
\text { (seis anos) }\end{array}$ & $\begin{array}{l}\text { Pele morena clara e cabelo raspado bem baixinho. É muito conversador } \\
\text { e sempre a professora chama sua atenção. Apresenta dificuldades em } \\
\text { realizar as atividades. Demonstra bastante carinho em relação a sua } \\
\text { amizade com os demais colegas de sala. Gosta de pular corda com a } \\
\text { meninas. No turno contrário à escola participa do projeto desenvolvido } \\
\text { pelo INAV. Mora com seis irmãos, porém não comenta sobre seus }\end{array}$ \\
\hline
\end{tabular}




\begin{tabular}{|c|c|}
\hline & pais. Destaca não brincar em casa. \\
\hline $\begin{array}{l}\text { Ronaldinho Gaúcho } \\
\text { (seis anos) }\end{array}$ & $\begin{array}{l}\text { Pele negra e cabelo curtinho. Parece um pouco tímido, mas esta sempre } \\
\text { espiando na mesa dos colegas e a professora chama sua atenção. } \\
\text { Apresenta dificuldades em realizar as atividades. Relata preferência em } \\
\text { jogar futebol, mas dentre as brincadeiras durante a recreação obsevei } \\
\text { que brinca mais de correr pelo espaço, polícia e ladrão e pega-pega. } \\
\text { Mora com pais e dois irmãos bem mais velhos que ele. }\end{array}$ \\
\hline $\begin{array}{l}\text { Neymarzinho } \\
\text { (sete anos) }\end{array}$ & $\begin{array}{l}\text { Pele clara e cabelo preto bem curto. É bem quieto, quase não o vejo } \\
\text { conversando ou andando pela sala. É bem aplicado na realização das } \\
\text { atividades. Na recreação observo que ele brinca mais no parque. }\end{array}$ \\
\hline $\begin{array}{c}\text { Kaislan } \\
\text { (sete anos) }\end{array}$ & $\begin{array}{l}\text { Pele clara e cabelo castanho claro. Parece-me bem tímido. Quase não } \\
\text { levanta da sua cadeira (senta na primeira). É seu primeiro ano na } \\
\text { escola. Na hora da recreação brinca mais de jogar bola na quadra } \\
\text { (futsal). No turno contrário à escola participa do projeto desenvolvido } \\
\text { pelo INAV. }\end{array}$ \\
\hline $\begin{array}{c}\text { Nelson } \\
\text { (sete anos) }\end{array}$ & $\begin{array}{l}\text { Pele clara e cabelo curto. Senta sempre na última cadeira da fileira. } \\
\text { Participa ativamente, como líder de um grupinho de crianças que se } \\
\text { organizam para jogar futebol na hora da recreação. Realiza as } \\
\text { atividades com facilidade, porém demonstra desorganização. Na hora } \\
\text { da recreação brinca sempre de jogar bola na quadra de futsal. Relata } \\
\text { que gostaria de ser jogador de futebol ou policial (profissão de seu pai). } \\
\text { Destaca sempre brincar muito em casa com irmãos e primos. É adepo a } \\
\text { jogos de viodeogame. }\end{array}$ \\
\hline $\begin{array}{l}\text { Joãozinho } \\
\text { (seis anos) }\end{array}$ & $\begin{array}{l}\text { Pele morena clara e cabelo curto. Parece um pouco tímido, pois não } \\
\text { conversa muito com seus colegas. Apresenta dificuldades em realizar } \\
\text { as tarefas, não levanta muito da cadeira e na recreação brinca mais de } \\
\text { jogar bola. É uma criança que falta bastante às aulas. }\end{array}$ \\
\hline $\begin{array}{c}\text { Yan } \\
\text { (seis anos) }\end{array}$ & $\begin{array}{l}\text { Pele morena e cabelo curto. É uma criança que parece ser bem } \\
\text { extrovertida, porém demonstra muita dificuldade em se expressar, } \\
\text { especialmente oralmente, pois não tem clareza ao falar, diferentemente } \\
\text { das demais crianças da turma. Apresenta dificuldade na execução das } \\
\text { tarefas. Na recreação gosta de brincar de jogar bola na quadra de futsal. } \\
\text { Reclama muito da agressividade dos colegas durante o jogo e que não } \\
\text { o deixam "pegar" na bola. Muitas vezes, o assistia simplesmente correr } \\
\text { na quadra como se fizesse parte de um time, mas não era o que } \\
\text { realmente acontecia. }\end{array}$ \\
\hline $\begin{array}{l}\text { Neymar Junior } \\
\text { (seis anos) }\end{array}$ & $\begin{array}{l}\text { Pele morena e cabelo curto, estatura baixa e corpo bem magrinho. Ele é } \\
\text { tão pequenino! Parece bastante tímido, pois quase não o vejo em } \\
\text { contato com as outras crianças em sala de aula. Apresenta bastante } \\
\text { dificuldade de aprendizagem ao realizar as tarefas. No momento da } \\
\text { recreação gosta mais de jogar bola e correr pelo gramado. Mora com }\end{array}$ \\
\hline
\end{tabular}




\begin{tabular}{c|l}
\hline $\begin{array}{c}\text { Jogador Neymar } \\
\text { (sete anos) }\end{array}$ & $\begin{array}{l}\text { Pele morena e cabelo curto. É um menino conversador com seus } \\
\text { colegas próximos, porém, não caminha muito pela sala durante as } \\
\text { atividades orientadas. No momento da recreação brinca mais de jogar } \\
\text { bola. Está sempre brincando de simular "lutinhas" com bonecos de } \\
\text { personagens de filmes. }\end{array}$ \\
\hline $\begin{array}{c}\text { Romeu } \\
\text { (sete anos) }\end{array}$ & $\begin{array}{l}\text { Pele morena clara e cabelo curto. Senta na primeira cadeira da sua } \\
\text { fileira. Brinca muito durante as atividades em sala. Sempre em pé, } \\
\text { caminhando pela sala ou conversando com seus colegas. Na recreação } \\
\text { gosta de jogar futebol, mas relata preferência em brincar de pique } \\
\text { esconde e correr pelo gramado ao redor do parque. Destaca também } \\
\text { gostar de assistir a jogos de futebol pela televisão, mas que queria } \\
\text { mesmo era conhecer um estádio de futebol. }\end{array}$ \\
\hline $\begin{array}{c}\text { Luis } \\
\text { (sete anos) }\end{array}$ & $\begin{array}{l}\text { Pele morena clara e cabelo preto e de corte arrepiado. Conversa muito } \\
\text { com seus colegas de sala, mas em especial com os que sente ao seu } \\
\text { lado (Mateus e Neymarzinho). É bem empenhado em realizar as } \\
\text { atividades em sala de aula. Na recreação brinca mais de jogar bola. } \\
\text { Gosta muito de cantarolar sozinho enquanto faz as atividades. Quando } \\
\text { não gosta de alguma coisa que seus colegas fazem ele tende a estapear } \\
\text { seus colegas. Essa atitude é sempre questionada pela professora que diz } \\
\text { que vai chamar seus pais, então ele pede desculpas para o colega } \\
\text { agredido. }\end{array}$ \\
\hline
\end{tabular}

Fonte: Da autora. Registros em diário de campo. 


\title{
ANEXO II - Parecer Consubstanciado do CEP
}

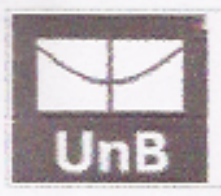

\author{
FACULDADE DE CIÊNCIAS DA \\ SAÚDE DA UNIVERSIDADE DE \\ BRASÍLIA - CEP/FS-UNB
}

\section{PARECER CONSUBSTANCIADO DO CEP}

\section{DADOS DO PROJETO DE PESQUISA}

Título da Pesquisa: PRÁTICAS CORPORAIS INFANTIS NOS ESPAÇOS E TEMPOS ESCOLARES:O PONTO DE VISTA DAS CRIANÇAS

Pesquisador: Tayanne da Costa Freitas

Área Temática:

Versăo: 2

CAAE: 31984014.0 .0000 .0030

Instituiçäo Proponente: FACULDADE DE SAÚDE - FS

Patrocinador Principal: Financiamento Próprio

\section{DADOS DO PARECER}

Número do Parecer: 772.378

Data da Relatoria: 20/08/2014

Apresentaçăo do Projeto:

O objetivo do estudo é identificar $\theta$ analisar práticas corporais de crianças nos espaços e tempos escolares de uma escola pública do Distrito Federal. Para tanto, será realizada pesquisa de campo com elementos da abordagem qualitativa em um Centro de Educação Infantil localizado na cidade de Riacho Fundo II/Distrito Federal. As técnicas utilizadas compreenderăo observação participante, coleta de desenhos e conversas com as crianças. Os participantes da pesquisa serăo 25 crianças de uma turma de 10 ano do ensino fundamental do CEI Riacho Fundo II, entre 6 e 7 anos, amostra de conveniência. As crianças deverão desenhar e discorrer sobre trés assuntos: qual a brincadeira favorita, o que mais gostam na escola e o que menos gostam.

\section{Objetivo da Pesquisa:}

Objetivo geral:

Identificar e analisar práticas corporais de crianças, considerando espaços e tempos escolares em uma escola pública do Distrito Federal.

Objetivos específicos

-Analisar os espaços e tempos estruturados pela escola para as práticas corporais das crianças.

-Identificar como as crianças fazem uso dos espaços e tempos propostos pela estrutura escolar,

Enderø̧̧⿻: Faculdede de Ciênciass da Saúde - Campus Darcy Fibciro

Bairro: Asa Norta CEP: $70.910-900$

UF: DF Município: BRASILIA

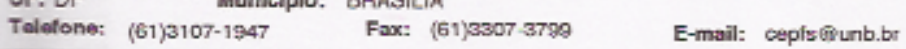




FACULDADE DE CIENCIAS DA
UnB
SAÚDE DA UNIVERSIDADE DE Plotoformo
BRASIILIA - CEP/FS-UNB

Continuaço do Parecer: 772.378

por intermédio das práticas corporais.

Âvaliaçāo dos Riscos e Benefícios:

O pesquisador afirma que a pesquisa não oferece riscos. $O$ benelicio mencionado é solidificar as pesquisas no campo da Educaçäo Fisica.

Comentários e Consideraçőes sobre a Pesquisa:

Pesquisa simples, sem grandes dificuldades metodológicas, sem risco aparente para os participantes, já que as intormaçōes serāo coletadas de forma lüdica, com brincadeiras e conversas informais. As informaçŏes serảo coletadas em sala de aula. Os desenhos serão produzidos após orientação coletiva, e os comandos serāo escritos no quadro. As falas serăo coletadas individualmente, em sala de aula, durante ou após a elaboraçăo dos desenhos, pela pesquisadora responsávei.

\section{Consideraçōes sobre os Termos de apresentaçāo obrigatória:}

Foram apresentados a folha de rosto preenchida e assinada pelo Diretor da Faculdade de Educação Física, - Termo de responsabilidade do pesquisador e o Termo de Concordáncia da Instituiçăo Co-Participante, assinado pela Vice-diretora do CEI Riacho Fundo II. Currículos dos pesquisadores. TCLE e TALE corrigidos segundo as solicitaçōes feitas anteriormente pelo CEP.

Conclusões ou Pendências e Lista de Inadequaçōes:

1) Informar o local onde as crianças tarāo as atividades planejadas (desenhar e conversar) - PENDÊNCIA ATENDIDA:

2) Informar se a coleta de dados será individual ou coletiva -PENDÉNCIA ATENDIDA:

3) Corrigir o TCLE (melhorar a descriçāo da coleta de dados de acordo com os questionamentos apresentados, colocar riscos e beneticios, e mencionar a indenizaçāo) -PENDÊNCIA ATENDIDA; 4) Mencionar, na metodologia, como será a coleta das assinaturas dos pais no TCLE -PENDENCIA ATENDIDA (será coletada em reunião pedagógica no inicio do segundo semestre. No mesmo trecho da metodologia menciona que a assinatura no TALE será colhida);

5) Para aplicaçāo do TALE às crianças, encurtar e simplificar o documento. Solicita-se escrever como se estivesse conversando com elas, sem usar termos técnicos, em poucas palavras, no nível de compreensäo da idade -PENDËNCIA ATENDIDA

\section{Situaçāo do Parecer:}

Aprovado

Necessita Apreciaçāo da CONEP:

Nāo

Enderepo: Faculdade de Clencies da Sa0de - Campus Darcy Ribeiro

Bairro: Asa Norte CEP: 70.910-900

UF: DF Municiplo: BRASILIA

Telafone: (61)3107-1947 Fax: (61)2307-3799 E-mail: cepts@unb.br 


\section{甲 \\ UnB}

\section{FACULDADE DE CIÊNCIAS DA SAUUDE DA UNIVERSIDADE DE BRASÍLIA - CEP/FS-UNB}

Continuarăo do Parsecer: 772.378

Consideraçōes Finais a critério do CEP:

Em acordo com a Resoluçăo 466/12 CNS, itens X.1.- 3.b. e XI.2.d, os pesquisadores responsáveis deverão apresentar relatórios parcial semestral e final do projeto de pesquisa, contados a partir da data de aprovaçắo do protocolo de pesquisa.

Os relatórios deverăo ser inseridos no Sistema Platatorma Brasil pelo icone "Inserir Notificaçāo" disponivel para projetos aprovados.

BRASILIA, 29 de Agosto de 2014

Assinado por:

Marie Togashi

(Coordenador)

Endereco: Faculdade de Ciencias da Saude - Campus Darcy Ribeme

Bairro: Asas Nor

CEP: 70.910 .900

UF: DF Municipio: BRASILIA

Teletone: (61)3107-1947

Fax: $(81) 3307-3780$

E-mail: cepfs@unb.br 